\title{
FINANCING CONDITIONS IN THE EURO AREA
}

by Louis Bê Duc, Gabe de Bondt, Alessandro Calza, David Marqués Ibáñez, Adrian van Rixtel and Silvia Scopel 
E U R P E A C E N TRAL BANK

\section{OCCASIONAL PAPER SERIES}

N0. 37 / OCTOBER 2005

\section{FINANCING CONDITIONS \\ IN THE EURO AREA}

by Louis Bê Duc, Gabe de Bondt, Alessandro Calza, David Marqués Ibáñez, Adrian van Rixtel and Silvia Scopel

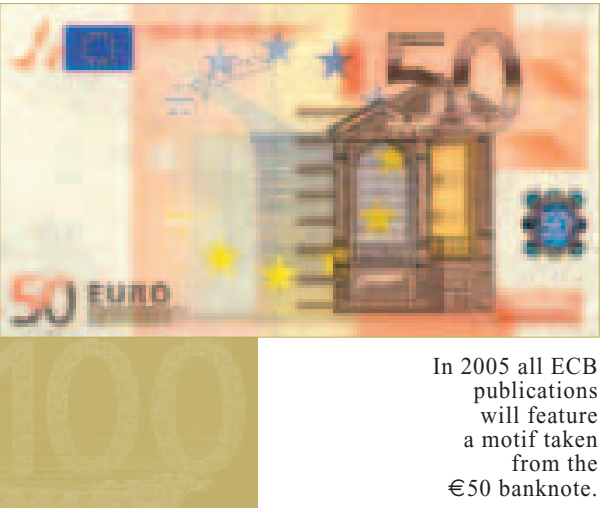

This paper can be downloaded without charge from the ECB's website (http://www.ecb.int) or from the Social Science Research Network electronic library at http://ssrn.com/abstract_id=8074l0.

* We are particularly grateful to all past and present contributors to the EAFC. We are also very grateful for the comments from Philippe Moutot, Francesco Drudi, Huw Pill and Thomas Westermann an anonymous referee and Elisabeth Keable for editing suggestions. 


\section{(C) European Central Bank, 2005}

\section{Address}

Kaiserstrasse 29

60311 Frankfurt am Main

Germany

\section{Postal address}

Postfach 160319

60066 Frankfurt am Main

Germany

Telephone

+496913440

Website

http://www.ecb.int

Fax

+496913446000

Telex

$411144 \mathrm{ecb} d$

All rights reserved. Any reproduction, publication and reprint in the form of a different publication, whether printed or produced electronically, in whole or in part, is permitted only with the explicit written authorisation of the $E C B$ or the author(s).

The views expressed in this paper do not necessarily reflect those of the European Central Bank.

ISSN 1607-1484 (print)

ISSN 1725-6534 (online) 


\section{CONTENTS}

ABSTRACT

I INTRODUCTION AND MAIN CONCLUSIONS

2 FINANCING CONDITIONS:THEORETICAL BACKGROUND

2.1 Indicators of financing conditions

2.2 Monetary policy transmission

2.3 Selected financing theories

3 EXTERNAL FINANCING OF NON-FINANCIAL CORPORATIONS

3.1 Introduction

3.2 Overall financing structure of non-financial corporations

3.3 Cost of corporate external finance 3.3.1 Spreads on corporate bonds

3.4 Sources of corporate external finance

3.4.1 Bank loans 21

3.4.2 Debt securities 25

3.4.3 Equity issuance 27

3.5 Balance sheet position of non-financial corporations

4 EXTERNAL FINANCING OF HOUSEHOLDS 32

4.1 Introduction 32

4.2 Cost of external finance 33

4.3 Sources of households' external finance

4.4 Balance sheet position of households

5.1 Introduction

5.2 Developments in bank lending spreads

5.3 Balance sheet position of banks

5.4 Selected evidence from capital markets 10
4 BIBLIOGRAPHY

51

ANNEX

Overview of indicators of financing conditions

10

7 


\section{ABSTRACT}

For central banks, the monitoring of financing conditions plays a pivotal role in assessing the actual transmission of monetary policy impulses to borrowers. This paper presents in detail some of the indicators and data used by the ECB to assess financing conditions in the euro area. It also shows how these indicators have been used to provide a broad assessment of developments in financing conditions in the euro area in recent years. The ECB's analysis of financing conditions is dynamic and seeks to reflect underlying changes in the euro area's financial structure. 
sector, altering banks' financing conditions and affecting banks' ability and incentives to Financing plays a very important economic role, as W. E. Gladstone stated in 1858: "Finance is, as it were, the stomach of the country, from which all the other organs take their tone". It is therefore not surprising that the European Central Bank (ECB) devotes special attention to developments in financing conditions in the euro area within the framework of its regular analysis of the economic and monetary environment. The financing conditions faced by non-financial corporations and households influence investment and consumption behaviour, and, in turn, economic activity and prices.

This paper defines financing conditions as the specific use of sources of finance and their terms and conditions at a particular moment in time. Financing conditions are the outcome of the specific supply of and demand for these sources (based on the particular financing needs of firms and households) and depend on the development of their specific prices or costs.

Financing conditions play an important role in the monetary policy transmission process. In evaluating monetary policy and determining the appropriate monetary policy stance, central banks can benefit significantly from a regular analysis of developments in financing conditions. The importance of such analysis has been heightened in recent years by the structural decline in interest rates in the run-up to Economic and Monetary Union (EMU) and the growth of private sector debt. Furthermore, the introduction of the euro has catalysed underlying trends in the euro area financial system that call for a more comprehensive understanding of the indicators of financing conditions in the euro area. For example, in recent years, possible additional sources of external finance that complement bank financing have become a reality for an increasing number of borrowers. At the same time, the introduction of the euro has changed the competitive landscape of the banking

I INTRODUCTION AND MAIN CONCLUSIONS advances in the modelling of financial markets and institutions have emphasised the importance of understanding how the financial system works in order to evaluate the impact of monetary policy changes on the real economy.

At the same time, it must also be recognised that financing conditions belong to a larger set of economic and financial aspects that central banks need to take into account when considering the appropriate monetary policy stance for maintaining price stability.

The ECB's analysis of financing conditions reflects the underlying changes in the euro area financial structure and aims to be as comprehensive as possible. It comprises an assessment of the cost of external financing for different instruments and on different markets, as reflected in changes in market interest rates, risk premia and equity prices. Price indicators are also analysed with regard to developments in the effective demand for financing in the form of credit and securities issuance. Particular attention is paid to developments in balance sheet indicators, which are interrelated with the cost of financing and may signal potential financial risks or imbalances in the economy. These data are cross-checked with qualitative opinions on credit risk assessment or demand for financing as reported by lenders (e.g. via the Eurosystem Bank Lending Survey) or published by rating agencies. The role of banks, which have a prominent position in the monetary transmission process, completes the picture.

This Occasional Paper presents in detail some of the indicators and data used by the ECB to assess financing conditions. It also shows how these indicators have been used to provide a broad assessment of developments in financing conditions in the euro area in recent years. The focus is on the euro area, while keeping in mind that the overall impact of financing conditions can differ across individual euro area countries 
in the light of the existing differences in financial, economic and legal structures, as well as in agents' preferences.

The paper is structured as follows: Chapter 2 provides a brief overview of the different indicators of financing conditions that will be analysed in the subsequent chapters. The key indicators identified for monitoring and assessing financing conditions are the cost of finance, the sources of finance and the balance sheet positions of borrowers and lenders. These, in turn, are theoretically linked to the main monetary policy transmission channels and to financing theories for non-financial corporations and households.

Chapter 3 deals with the external financing of the non-financial corporate sector, i.e. debt and equity financing. It provides a comparative overview of the corporate finance structure in the United States, Japan and the euro area. In order to understand the developments in external financing, three main groups of indicators are considered: the cost of external financing, the amount of financing raised, and the overall balance sheet position of nonfinancial corporations.

It examines at length some of the indicators that the ECB has developed for monitoring and assessing developments in these variables, and how it has used them to analyse developments in the euro area over recent years. It argues that the cost of capital in the euro area has been reduced by a number of factors, including the switch to a regime of low and stable inflation and increased financial integration of capital markets. More recently, indicators of the cost of capital have shown some volatility, reflecting the impact of a cluster of different shocks, for example, the significant correction of stock prices and the post-2000 economic slowdown, the September 2001 terrorist attacks in the United States and various corporate accounting scandals. Chapter 3 shows that bank loans still account for the bulk of external debt financing to euro area nonfinancial corporations, but that debt security issuance has grown significantly, particularly during the first few years after the introduction of the euro. Equity issuance also hit record levels between 1999 and 2001, which was partly due to the privatisation of a number of (partially) state-owned companies and a large number of new company listings, especially in the telecommunication, media and technology sectors.

Chapter 3 also deals with the balance sheet situation of non-financial corporations, which influences the external financing costs of these corporations and their ability to access external financing. The indicators highlight the sharp rise in corporate leverage between the mid1990s and 2001. Since 2003 corporate leverage has improved somewhat, reflecting costcutting efforts and balance sheet repairing in a context of rising equity prices. Nevertheless, corporate leverage, especially for large companies and some individual sectors (e.g. the telecommunications sector), has so far not returned to the level preceding the boom in corporate acquisitions during the late 1990s. To some extent, this could reflect persistently high earnings expectations and possibly some structural shifts to take account of debt financing in an environment of low interest rates and increased corporate debt affordability.

Chapter 4 describes indicators of financing conditions for households. The evidence presented suggests that there has been substantial growth in loans to households since 1998. As in the corporate sector, this trend appears to be largely due to the significant decline in interest rates. Overall, the rise in debt levels has been partially offset by the decline in lending rates so that the interest service burden of households has been largely contained. In addition, the rise in mortgage loans has been closely associated with buoyant real estate markets in a number of euro area countries. Cross-country developments reflect the role of lower interest rates and higher housing prices. At the same time, there appears to be some convergence of debt levels across 
euro area countries. On the whole, the rise in household debt since 1998 has been very steady, although in the euro area its level remains below those reported in other industrialised regions. Admittedly, the higher level of household indebtedness tends to increase financial risks, as it heightens the sensitivity of households to market interest rates changes. At the moment, however, there are no signs of any imminent threat to households' future income or access to credit in the euro area as a whole.

Chapter 5 considers in detail the role of banks, which are instrumental in the allocation of funds from savers to borrowers. It examines some of the major indicators frequently used to analyse the situation of the banking sector from a financing conditions perspective, including the Bank Lending Survey and spreads of lending rates over comparable market rates. Banks' indicators are split into those derived from accounting information and those derived from financial markets information. The developments of both sets of indicators show that, after a downturn in the banking sector in 2001 and 2002, banks' soundness and profitability have more recently improved. This seems to suggest that the financial condition of the euro area banking sector is unlikely to hamper the transmission of monetary impulses to borrowers or significantly impair their access to financing. The analysis of financing conditions, as presented in the previous chapters, is crosschecked with the results of the euro area Bank Lending Survey. This survey is a particularly useful source of information for understanding the development of financing conditions, as it collects answers to a comprehensive set of questions on credit conditions from those at the centre of the credit transmission process (i.e. the banks). The information derived from the Bank Lending Survey was assessed from early 2003 to early 2005, and it was found to support the analysis of other indicators during this period, suggesting a loosening of the financing conditions for corporate and household borrowers in the euro area. BACKGROUND

2 FINANCING CONDITIONS: THEORETICAL BACKGROUND

This chapter provides a brief overview of the indicators of financing conditions that will be analysed in the next three chapters (Section 2.1) and links them theoretically with the main monetary policy transmission channels in which financing conditions play a role (Section 2.2), as well as with selected financing theories for non-financial corporations and households (Section 2.3).

\section{INDICATORS OF FINANCING CONDITIONS}

Table 1 summarises the key indicators for monitoring and assessing financing conditions. They are grouped under the cost of finance,

Table I Overview of indicators of financing
conditions
Cost of finance
Real cost of bank and market-based debt and equity finance
Overall real cost of corporate finance
Premia on debt financing
- Corporate bond spreads (broken down by rating and
sector)
- Credit default swap spreads by sector
Sources of external finance
Bank lending
- Non-syndicated lending
- Syndicated lending
- Loan demand and its determinants
(Bank Lending Survey)
Bond issuance
- Debt securities issued by non-financial corporations and
non-monetary financial corporations
- Non-financial corporate bond issuance (broken down
by rating and sector)
Equity issuance
- IPO and SPO issuance
- Equity issuance (broken down by sector)
Balance sheet positions
of borrowers
- Corporate credit risk (rating) changes
- Leverage ratios
- Sustainability ratios
- Expected earnings per share
- Financing gaps
of lenders
- Credit standards and their underlying factors
(Bank Lending Survey)
- Banks' competitive conditions (Bank Lending Survey)
- Bank capital ratios
- Bank credit risk rating changes
- Bank profitability ratios
- Bank (expected) earnings per share


sources of finance and the balance sheet positions of borrowers and lenders. Appendix I provides a detailed description of the actual indicators used in this paper, as well as their sources and definitions.

In the case of the cost of finance, the user costs of capital and risk premia on debt financing are the key indicators to be monitored and assessed. This paper examines the real cost of bank and market-based debt (as well as the aggregate real cost of debt) and the real cost of equity. It also analyses some external finance premia, such as corporate bond spreads. As regards the sources of finance, bank lending and bond and equity issuance are monitored and assessed regularly. The finance purpose of syndicated lending and several sector breakdowns of this lending are also examined. The balance sheet positions of both borrowers and lenders are described in the next three chapters using a number of indicators, such as credit rating changes, leverage ratios, indebtedness and bank capital ratios.
It should be kept in mind that, in the remaining chapters of this paper, the focus is on the financing conditions at the euro area level, which may deviate from those at the country level, among other reasons because the financial, economic and legal structures and habits of non-financial corporations, households and banks might differ across euro area countries.

\subsection{MONETARY POLICY TRANSMISSION}

Monetary policy affects financing conditions in particular, although not exclusively, through two main transmission channels: the interest rate and the credit channel (ECB, 2000 and Angeloni, Kashyap and Mojon, 2003). The latter is divided into a bank lending and a balance sheet channel. These transmission channels operate via the costs and sources of finance and the balance sheet position of nonfinancial corporations, households and financial intermediaries.

\section{Chart I Monetary transmission channels and financing conditions}

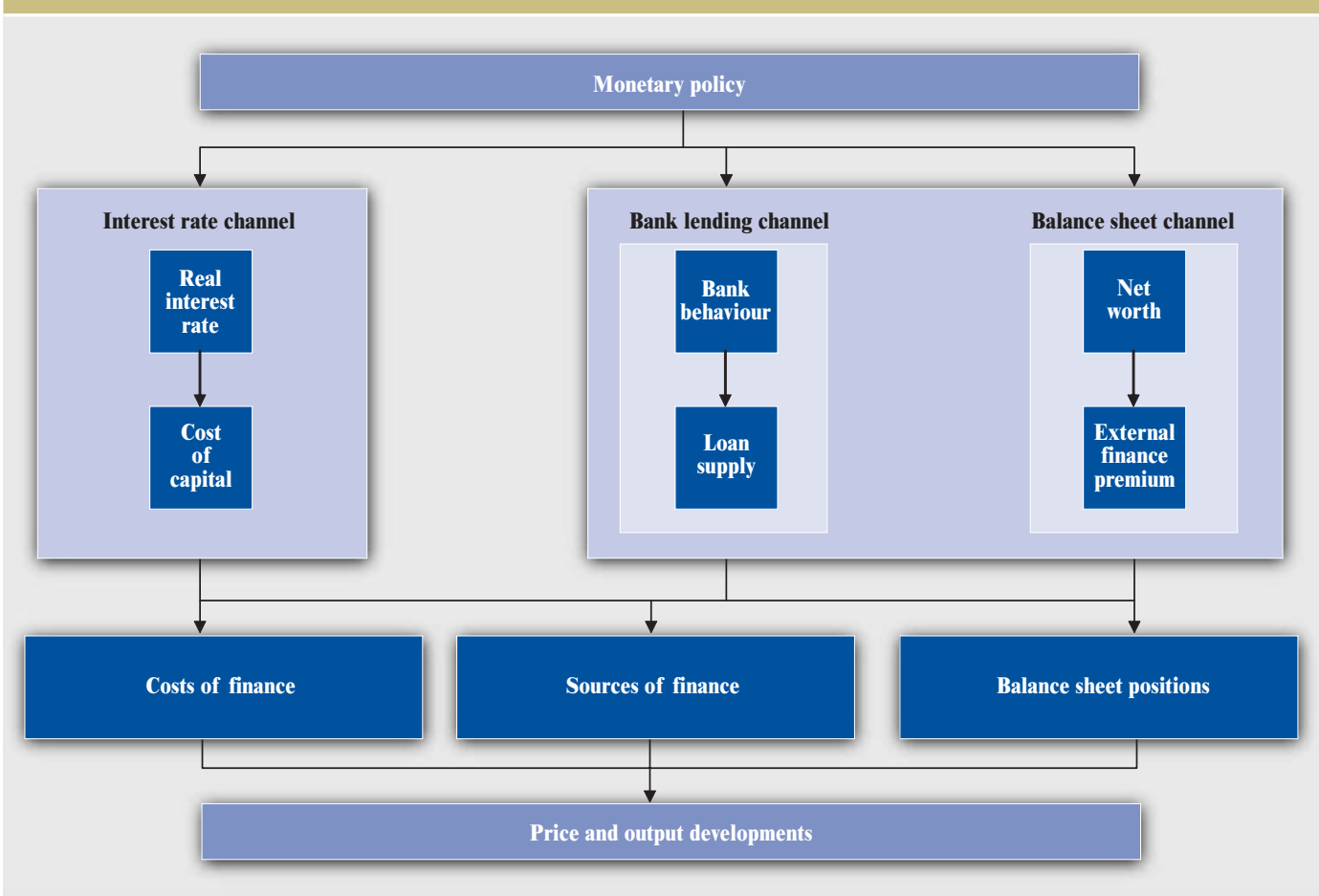


Chart 1 illustrates this in a very schematic and simplified way. In line with the overview of the indicators of financing conditions as presented in the previous section, the focus is on the costs and sources of finance and the balance sheet positions.

In essence, the interest rate channel theory contends that monetary policy affects the real interest rate which, in turn, affects the real cost of the different sources of finance across the maturity spectrum. This channel is thus crucial for the cost of finance, which is then expected to affect the sources of finance and balance sheet positions of non-financial corporations and households. Owing to their pivotal role within the financial system, banks are instrumental in transmitting changes in official interest rates to bank lending rates.

The credit channel of monetary policy focuses on the availability of external finance from banks depending on the state of the financial sector (i.e. the bank lending channel) and on financial market imperfections resulting from the different levels of information on the balance sheet situation of borrowers (i.e. the balance sheet channel).

The bank lending channel, often termed the "narrow" credit channel, emphasises the role played by bank credit supply in the transmission process. The potential relevance of the bank lending channel depends on the extent to which central bank actions determine bank behaviour in terms of loan supply and the degree of bank dependence in the economy.

According to the bank lending channel theory, monetary policy may have asymmetric effects. Monetary policy is expected to have a relatively strong impact on banks with a small buffer stock of liquid assets and/or on undercapitalised banks, as these banks might be less able to offset a monetary policy tightening, as well as on non-financial corporations and households, which are unable to resort to other sources of external or internal finance.
In this regard, non-financial corporations with limited access to financial markets are typically small, with a high degree of financial leverage, and should therefore be more affected by monetary policy changes than non-financial corporations that can easily tap into money/ capital markets. These "financing constraints" and "liquidity constraints" may cause corporate investment and household consumption expenditures to be relatively sensitive to the availability of internal financing, i.e. to movements in cash flow (Angeloni, Kashyap, Mojon and Terlizzese, 2003) and disposable income (de Bondt, 1999).

The importance of bank capital for bank (lending) behaviour is also recognised by regulators, who have given bank capital a prominent role in prudential regulation, with, for example, the introduction of the new Basel Accord on capital requirements (Chami and Cosimano, 2001). In fact, when a bank's capital falls below the regulatory minimum, it cannot increase its lending without raising additional capital, which could be prohibitively expensive at that particular point in time. Furthermore, a change in monetary policy could have an impact on the interest rate mismatch of banks which, in turn, has an impact on bank profitability and thus on the value of bank capital, thereby possibly affecting the supply of loans by banks (Van den Heuvel, 2002).

Thus, the main lesson to be learnt from the bank lending channel theory is that indicators that provide insights into the degree of bank dependence, financing constraints in the economy and banks' conditions are of key importance in monitoring financing conditions. Relevant factors in this regard include the economic importance of different sources of finance, the degree of substitution between different sources of finance by non-financial corporations and households, and the type of funding by banks. Bank (lending) behaviour can be affected by a number of factors, such as the bank's capital position, profitability, liquidity, funding costs and credit ratings. 
The balance sheet channel theory stresses that asymmetries of information - or differences in the levels of information between lenders and borrowers - in credit markets are a vital element in the propagation and amplification of an initial monetary policy shock. This transmission channel shows that debt market imperfections may make external finance more costly than internal financing, i.e. the external finance premium could make it more difficult for borrowers to obtain funds in the event of a fall in the value of the assets pledged as collateral for debt. This propagation phenomenon is known as the financial accelerator effect (Bernanke and Blinder, 1988; Gertler, 1988; Bernanke and Gertler, 1989; Greenwald and Stiglitz, 1993). It also highlights the fact that some borrowers may be more vulnerable to changes in financing conditions than others. A rise in interest rates may have a much greater negative impact on the economy if the borrowers' balance sheet positions are already weak.

Hence, the main lesson to be drawn from the balance sheet channel theory is that a change in monetary policy could have a potential impact on borrowers' balance sheet positions or their net worth. This, in turn, modifies the external finance premium and consequently the overall terms of credit for borrowers. Key indicators are the premia on debt financing, such as corporate bond spreads and credit default swaps, corporate credit risk ratings, and corporate and household balance sheet indicators, such as the degree of indebtedness.

Apart from the interest rate and credit channels, it can be argued that other monetary transmission channels are, more indirectly, relevant to financing conditions. For instance, inflationary expectations are crucial for determining interest rates. All monetary policy actions that affect these expectations are therefore relevant to financing conditions. Uncertainty in the economy, for example about the creditworthiness of borrowers and their net worth and thus about their ability to pay off debt contracts, directly affects the balance sheet channel of monetary policy. Likewise, monetary policy movements could alter the equity risk premium reflected in equity prices, thereby affecting the cost of raising equity finance. Wealth effects are mostly ignored, since they relate more to consumption and investment decisions than to the financing of these expenditures, although they do affect the balance sheet positions of borrowers and thus the balance sheet channel of monetary policy. This also applies to the transmission channels through financial asset prices, such as the exchange rate.

Finally, the timing, effect, and nature of the transmission channels working through financing conditions might differ according to the institutional environment (Fase and de Bondt, 2000; Angeloni, Kashyap, Mojon and Terlizzese, 2003). Differences in institutional arrangements (financial, economic and legal structures) are potential causes of differences in monetary transmission mechanisms among countries. Examples include the degree of variable rate versus fixed-rate financing, the (legal) possibility of refinancing without additional costs and home equity withdrawal, but also the economic structure, since some industries are more sensitive to interest rate changes than others.

\subsection{SELECTED FINANCING THEORIES}

Some of the main microeconomic concepts used in corporate finance, such as asymmetric information or agency problems, may have a significant macroeconomic impact. This section considers, very succinctly, some of these concepts that are explicitly or implicitly discussed throughout this paper.

In this regard, the problems that arise due to asymmetries of information between borrowers and lenders could influence borrowers' capital structure, as well as the conditions of and accessibility to external financing. In practice, households also face such information problems which, combined with a large number of institutional, legal and historical characteristics, 
determine the use of specific sources of finance by borrowers and the development of an economy's financial structure.

Contrary to the Modigliani-Miller (1958) assumptions, which resulted in the "irrelevance hypothesis" regarding financing by non-financial corporations and households, financial markets and financing decisions are characterised by agency costs and asymmetric information (Hubbard, 1998; Amaro de Matos, 2001). Agency costs arise from conflicts of interest between various groups of stakeholders, such as management, debtholders and shareholders. Information asymmetries, such as adverse selection and moral hazard (see Box 1), may influence the financing decisions of non-financial corporations and households.

The concepts of agency costs and asymmetric information feature prominently in the theory of corporate finance, and are fundamental to understanding the daily financial decisionmaking process of non-financial corporations. In corporate finance theories based on agency costs, the capital structure of a firm is seen as a kind of contract that can reconcile different incentives (principal-agent problems) that exist between the firm's owners (shareholders) or principals and managers or agents. The optimal capital structure is then the specific combination of debt and equity that leads to an optimal incentive structure.

\section{Box I}

\section{ADVERSE SELECTION AND MORAL HAZARD}

Asymmetric information between lenders and borrowers may cause great problems, which are generally referred to in literature as "adverse selection" and "moral hazard".

\section{Adverse selection}

Adverse selection results from information asymmetries related to the nature of the contract to be signed by prospective lenders and borrowers. For example, in a standard loan contract, a provider of funds or lender is confronted with a large set of heterogeneous borrowers, some of which might have an incentive not to repay the loan (i.e. to default). Since the lender cannot distinguish clearly between various types of borrowers in advance, its lending behaviour may be affected by this lack of information: it might refuse to provide any funds to certain borrowers, even though these borrowers offer a higher rate and may be perfectly capable of repaying the funds. This problem is particularly relevant for new and risky companies which have not yet established stable relationships with providers of funds and which also cannot be monitored closely and accurately, as objective information on these companies is often not available. For well-established companies with long-term track records of performance and positive long-term relationships with lenders, adverse selection problems may be less significant.

\section{Moral hazard}

Moral hazard arises from information asymmetries affecting the period after a contract is signed. After obtaining funds, a borrower might start to engage in risky activities that could be highly profitable, but which could also lower the likelihood that the funds will be repaid to the lender. Thus also here, a lender might decide either not to extend any funds or to restrict the amount of funds granted to certain borrowers. 
All in all, different theories on corporate financing decisions have been developed, which, in principle, can also be applied to households. These include, for example, "optimal" capital structure and "trade-off" theories, which focus on specific debt-equity ratio targets (Allen, 1989; Graham and Harvey, 1999; Zingales, 2000; Amaro de Matos, 2001), signalling models (Leland and Pyle, 1977; Ross, 1977) and the "pecking-order" theory (Myers, 1977 and 1984; Myers and Majluf, 1984; Myers, 2003). According to the "trade-off" theory, firms maintain debt-equity ratios that optimise the value of the firm, and they achieve these by trading off the tax benefits of debt against the costs in terms of bankruptcy and liquidation (Myers, 2003). Signalling models assert that information asymmetries lead to insiders choosing a capital structure that supplies outside providers of funds with information (signalling) from the firm and that may affect the value of the firm (Leland and Pyle, 1977; Ross, 1977). The latter theory contends that there is a "pecking order" of sources of finance, which is based on their relative cost. Accordingly, corporations' first preference is internal finance, which is the cheapest form of finance, followed by debt financing, and lastly equity financing. Indeed, equity financing is the most sensitive to costs arising from conflicts between various stakeholders and therefore the most expensive to use.

The aforementioned theories on corporate financing decisions at the firm or micro level are increasingly based on the macro financial structure of an economy. The link between literature on corporate finance and the (optimal) capital structure of the firm on the one hand, and investigations of the macro financial structure on the other, has been established via financial intermediation models, which describe the effects of information asymmetries in financial markets on the allocation of funds and corporate financing decisions (Gertler, 1988; Walsh, 1998). These models assert that information problems could lead to inefficiencies in financial markets that may have real effects on the economy, consequently affecting the choices of sources of corporate finance (Greenwald et al., 1984; Bernanke and Gertler, 1987 and 1989). For example, as a result of adverse selection problems, investors may not be able to differentiate between various nonfinancial corporations issuing equity or debt securities and may therefore be somewhat reluctant to invest in such securities. Consequently, only investors more prone to risk (or better able to diversify), such as venture capital firms, will invest in securities issued by new and risky companies. Furthermore, information asymmetries and monitoring costs in financial markets may result in a general, macroeconomically significant situation of credit rationing.

All in all, it may be argued that financing through financial intermediaries is an effective means of mitigating the adverse selection and moral hazard problems that exist in transactions between lenders and borrowers. In addition, by operating as "delegated monitors" of borrowers on behalf of many small savers, banks (or monetary financial institutions (MFIs)) save on aggregate monitoring costs (Diamond, 1984). Thus, by collecting information and monitoring borrowers, banks can be at an advantage. In this regard, it has been argued that banks are "special" or "unique" (James, 1987; Schmidt et al., 1999). There are also other ways of limiting the problems arising from information asymmetries and these include the provision of publicly available information on the quality of non-financial corporations (such as ratings) and requiring borrowers to provide collateral that can be liquidated by the lender in the event of default.

The degree of information asymmetries at the macro level can be affected by various factors. For example, a well-developed accounting system combined with a relatively high degree of disclosure might promote the use of marketbased financing, as corporate information is more readily available to investors at relatively low cost. Differences in financial regulatory frameworks and legal sanctions might affect the provision of information to financial 
markets and consequently stimulate the development of a predominantly market-based or bank-based financial structure. The specific forms of corporate finance and the nature of the financial structure are therefore affected by various institutional characteristics of a specific economic system. This also implies that, to some extent, the financing decisions of non-financial corporations may be influenced by government policies that affect these characteristics. Overall, it is important to stress that a bank-oriented financial structure is a priori neither more nor less efficient than a securities-based structure. Rather, it is the complementarities of financing options and a competitive and sound financial system that contribute to economic efficiency.

To conclude, it is also important to emphasise that the above focused mainly on the corporate sector, since the majority of the financing theories advanced in earlier literature referred to corporations. However, it is clear that most of the issues discussed, such as asymmetries of information between lenders and borrowers, also apply to the financing conditions of households. Indeed, there is a recent and burgeoning strand of literature that looks at the effects of households' leverage (and their collateral) on the monetary policy transmission mechanism, as well as on its broad potential macroeconomic impact (Aoki, Proudman and Vlieghe, 2004).

\section{EXTERNAL FINANCING OF NON-FINANCIAL CORPORATIONS}

\section{I INTRODUCTION}

As indicated in the previous chapter, the financing conditions of borrowers are a major driving force of economic activity. This chapter explains the various indicators that the ECB has developed in order to monitor and interpret the financing conditions of nonfinancial corporations. It also shows how they have been used to analyse developments in euro area financing conditions over recent years.
To put these indicators into perspective, this chapter starts by presenting the general characteristics of the external financing of nonfinancial corporations in the euro area and comparing them with other major economic areas (see Section 3.2). The analysis of the pattern of the external financing of nonfinancial corporations in the euro area is then separated into three main components. First, the cost of external financing, i.e. bank lending interest rates, corporate bond yields and the cost of quoted equity, is examined with regard to the ECB role in steering short-term risk-free interest rates (see Section 3.3). Secondly, the specifics of the various sources of external corporate finance are explored, particularly funds raised in the form of bank loans, debt securities and listed equity (Section 3.4). Thirdly, the overall balance sheet positions of non-financial corporations in the euro area are described according to three main types of macroeconomic indicators: financing gaps, leverage ratios and the debt service burden (Section 3.5).

Analysis of the data suggests that the cost of financing has declined in the euro area over recent years for a number of reasons, including the switch to a regime of low and stable inflation and greater financial integration. After the start of Stage Three of EMU, the growth in loans (still the major source of external corporate financing) rose significantly, reaching a two-decade peak in 2000. This was partly due to strong demand for credit to finance financial transactions. Thereafter, demand for bank loans declined significantly, partly as a result of the downturn in economic activity.

Overall, the introduction of the euro has created a more competitive financing environment, in which non-financial corporations have tapped into the euro area corporate bond market in order to fund mergers and acquisitions (M\&As), as well as to meet investment expenditure and working capital financing needs. These factors have also promoted the development of the high-yield
3 EXTERNAL

FINANCING OF NON-FINANCIAL CORPORATIONS 
segment in the euro area corporate bond market.

In addition to debt financing, equity issuance activity hit record levels between 1999 and 2001. This development was initially due to the extremely high level of M\&A activity. It was also driven by the privatisation of a number of (partially) state-owned companies and a large number of new company listings, especially in the telecommunications, media and technology (TMT) sectors. Specialised stock markets for so-called growth companies also recorded spectacular growth around that time. Following the correction in stock prices, issuance activity declined significantly, but has picked up somewhat since mid-2003, reflecting both business cycle developments and only modest demand due to the relatively high cost of equity.

The balance sheet position of euro area nonfinancial corporations deteriorated from the mid-1990s up to 2001, with corporate leverage rising significantly in order to finance sizeable M\&As, as well as, among other things, UMTS
(Universal Mobile Telecommunications System) licence auctions in several European countries. While the debt-to-income ratio moderated after 2001, other indicators of leverage (such as debt-to-equity ratio) continued to rise to reach historical highs in 2002 , before starting to fall. The leverage ratio of non-financial corporations has improved somewhat since 2003, reflecting cost-cutting efforts and balance-sheet adjustments in a context of improving equity prices.

\subsection{OVERALL FINANCING STRUCTURE OF NON-FINANCIAL CORPORATIONS}

The main characteristics of the corporate finance structures in the euro area, the United States and Japan, as well as the external financing patterns of corporations, can be described on the basis of the developments in debt and equity financing (see Box 2). The former consists of bank lending and the issuance of debt securities by non-financial corporations, while the latter involves the issuance of public and private equity by the corporate sector.

\section{Box 2}

\section{INSTRUMENTS OF EXTERNAL CORPORATE FINANCE}

The main forms of corporate finance that are raised externally are debt and equity. Debt consists of external parties' financial claims that have to be repaid by the firm in specific amounts at a certain interest rate at periodic intervals (Milgrom and Roberts, 1992; Mishkin and Eakins, 1999). Equity constitutes a claim on the future profits of the firm by the providers of these funds (the shareholders). Unlike debt, equity is characterised by the fact that it does not have to be repaid to external parties.

\section{Debt}

The main forms of debt are (bank) loans and debt securities. Debt securities can be privately or publicly placed with investors. In the case of private placements, debt securities cannot be traded easily on the financial markets, as they are placed with specific investors. In the case of publicly issued debt securities, trading possibilities are much greater (marketable debt securities). The interest paid on debt securities reflects, among other things, differences in the creditworthiness of the respective issuers, which, in turn, reflects their prospective ability to meet the principal and interest payments of the debt issued. In general, debt securities are distinguished on the basis of qualifications of their creditworthiness (ratings) assigned by rating companies. A common differentiation is between investment-grade and sub-investment-grade (or high-yield) debt 
securities. Following the ratings that are commonly used in the financial markets, investmentgrade securities are those rated BBB or above by Standard \& Poor's and Fitch's Investors Service, and Baa or better by Moody's Investors Service, whereas sub-investment-grade securities have lower ratings. The creditworthiness and the ratings of debt securities depend, among other factors, on the guarantees that are attached to these instruments. For instance, debt that is secured by collateral, such as real estate in the case of a mortgage, normally has a better rating than unsecured debt. Finally, non-financial firms also finance their activities by resorting to trade credits and advances (which are financial claims arising from the direct extension of credit by suppliers and buyers for goods and services transactions). Trade credit can be an important source of finance for non-financial corporations.

\section{Equity}

Equity can also be issued privately in the form of unquoted shares and venture capital, and publicly via shares that are listed on a stock exchange (quoted shares). Private equity consists of equity investments in the non-quoted securities of private and public firms (see Fenn et al., 1995). Venture capital is often provided by investors, such as specialised venture capital firms, as start-up money to finance new high-risk companies, for example ones specialising in new technologies, in return for an equity position in the firm. Venture capital firms often obtain positions on the boards of the firms in which they invest in order to exercise control over managerial decision-making. For reputation reasons and financing considerations, firms may decide at a certain moment to substitute unquoted for quoted shares (or public equity). The listing of a firm's shares on a stock exchange improves its access to the capital markets, as potential investors receive better information due to the improved transparency and disclosure of information requirements that are part of the listing conditions. Furthermore, listed companies often have to meet certain financial performance criteria and accounting standards, which should boost investor confidence in the firm. Finally, when a firm is listed, investors can observe the movement of its share price and consequently form a better opinion of the firm's investment potential. In a number of countries, in addition to the main stock exchanges, specialised exchanges that aim at new or high-growth companies have been established. These markets play an important role in the provision of highrisk capital for potentially highly successful companies that may encounter difficulties in obtaining financing from financial intermediaries, such as banks.

\section{Hybrid}

There are also some financial instruments that cannot be classified as equity or debt, as they have characteristics of both. These hybrid instruments have gained considerable importance in the last few decades. Some are also classified as financial innovations, i.e. new financial instruments and techniques that aim to provide cheaper or more flexible sources of corporate finance. Examples of such instruments are convertible bonds and warrants. Convertible bonds give their owners the right to convert the bond into a certain number of shares of the issuing firm (Fabozzi and Modigliani, 1996), whereas warrants provide their holders with the right to buy shares in a firm at a certain price and are often attached to bonds (Damodaran, 1999). Another type of financial innovation that has started to play an important role in corporate financing is financial derivatives. In general, firms use these to hedge against market risks, such as interest rate and foreign exchange risks, or to tailor the features of their debt to the specific needs of the firm. Examples of such derivatives are options, forward and futures contracts and swap agreements (Hull, 2000; Mishkin and Eakins, 1999). 
The general perception is that financing through financial markets, i.e. direct finance, is more widespread in the United States, whereas financing via financial intermediaries, particularly by banks (i.e. external indirect finance), is more widespread in the euro area and Japan (Allen and Gale, 2000; Byrne and Davis, 2003). In addition, there is more and more evidence to suggest that the euro area financial structure has become more marketbased over the past decade (ECB, 2001; Rajan and Zingales, 2003). In order to obtain a comparative overview of the financial structures across different economic areas, Table 2 shows the development of the main components of external corporate financing in Japan, the United States and the euro area.

At end-2003 outstanding bank loans to nonfinancial corporations in the euro area and the United States were at rather similar levels, at around $40 \%$ of GDP (see Table 2). These figures indicate the importance of financial intermediation through banks in the euro area, particularly in comparison with the United States. ${ }^{1}$ In both areas, bank loans as a percentage of GDP increased steadily from 1995 until 2001, and then declined somewhat. By contrast, bank loans to non-financial corporations in Japan amounted to around 60\% of GDP at end-2003, down from a high of almost 90\% of GDP in 1995. This seems to partly reflect the impact of the Japanese banking crisis in the 1990s on bank lending and the increasing recourse to alternative sources of corporate finance (van Rixtel, 2002).

The other main component of debt financing, i.e. the issuance of debt securities, is smaller in the euro area than in the United States and Japan. From a time perspective, however, the issuance of debt securities by non-financial corporations in the euro area has increased steadily, rising from around $4.5 \%$ of GDP at end-1990 to $7.2 \%$ at end-2003. The use of debt financing in the form of securities issuance by euro area non-financial corporations represented a smaller percentage of GDP at end-2003 than in both the United States and
Japan. Despite significant growth in the euro area debt securities market, some market segments, such as those for debt with a low credit rating or unrated debt, have remained relatively underdeveloped, although they are expected to continue to grow in the coming years (de Bondt and Marqués Ibáñez, 2005).

Turning to the equity market, a commonly used indicator of its importance is the market capitalisation of stocks traded in terms of GDP. Overall, the euro area's stock market capitalisation has increased, rising from 20\% of GDP at end-1990 to about 54\% of GDP at end-2003 (see Table 2). However, stock market capitalisation was as high as $86 \%$ of GDP at end-2000. Total stock market capitalisation in the euro area has remained significantly lower than in the United States, and the gap between stock market capitalisation in terms of GDP in the United States and the euro area has even widened, from around 35 percentage points at end-1990 to around 75 percentage points at end-2003. In Japan, however, stock market capitalisation declined from $90 \%$ of GDP at end-1990 to around 63\% of GDP at end-2003, mostly reflecting significant declines in stock prices over this period.

It should be noted, however, that the considerable difference in the issuance of shares reported in Table 2 partly lies in the fact that, contrary to the United States, a large part of equity issued by euro area companies is nonquoted (non-quoted shares primarily include shares issued by limited liability companies). Indeed, while, in the United States, the majority of corporate equities are listed, the

1 The higher level of reliance on indirect finance in the form of bank loans in the euro area compared with the United States does not necessarily imply that the financial structure of the euro area is less efficient than that of the United States, which is oriented more towards market financing. For example, a bank-based system may reduce information asymmetries through long-term relationships, thereby allowing banks to allocate funds more efficiently. Allen and Gale (1995 and 1997) have shown that bank-based financial systems may provide better intertemporal risk sharing than market-based systems, and thus the former may achieve a higher level of welfare than the latter (see also Boot and Thakor, 1997). 


\section{Table 2 Corporate finance structure in the euro area, United States and Japan}

(as a percentage of GDP)

Bank loans to non-financial corporations

euro area

United States

Japan

Total stock market capitalisation

euro area

United States

Japan

Debt securities from non-financial

corporations

euro area

United States

Japan

22.3
8.5

1990

1995

2000

2003

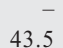

102.8

19.9

53.5

90.3

8.5

Sources: ECB, Federal Reserve, Bank of Japan financial accounts, World Federation of Exchanges, Bank for International Settlements (BIS).

Note: Euro area GDP for 1990 is estimated.

major part of equity liability of non-financial corporations in the euro area is non-quoted. The proportion of non-quoted shares was estimated to be around three-quarters of all equity liability in the euro area in 2003. If the volume of non-quoted shares were added to total financing of non-financial corporations in the euro area, the latter would be rather similar, in terms of GDP, to that in the United States.

\subsection{COST OF CORPORATE EXTERNAL FINANCE}

Monetary policy impulses are essentially transmitted to borrowers through the cost of external finance. This indicator - which is often simply referred to as the cost of financing - is therefore one of the main determinants of borrowers' financing decisions. Not surprisingly, there is extensive literature on the comparative costs of financing in different financial structures. ${ }^{2}$

In most studies, the cost of external finance is often calculated as a weighted average of the costs of the individual components of external finance. Furthermore, this weighted or composite cost of external finance is regularly adjusted for inflation in order to provide a better overview of the development over time of the fundamental costs of financing for nonfinancial corporations.

In broad terms, four main components of the cost of external financing are considered: the short and long-term bank lending interest rates, the corporate bond yield for non-financial corporations and the cost of quoted equity, all adjusted for inflation to obtain real rates (see Chart 2). The bank lending interest rates are based on the interest rate statistics for the official bank interest rate (MFI) in the euro area. The cost of corporate bonds is based on the euro broad market index for corporations as calculated by Merrill Lynch (see Appendix 1), while the cost of quoted equity follows a socalled "three-stage Gordon Dividend Discount Model" (for a detailed explanation, see ECB, 2005a).

The overall cost is calculated by combining these four different components of external financing into a single composite indicator by weighting the rates of the different external financing sources (i.e. debt and quoted equity) on the basis of their outstanding stocks, thus

2 (Becht et al., 2003 and La Porta et al., 1998). 
assuming that no structural change in the financing composition has taken place (see ECB, 2005a).

\section{- Developments in the cost of corporate external finance}

The introduction of the euro has lowered the cost of financing of non-financial corporations in the euro area by anchoring inflation expectations, eliminating currency risks among the euro area Member States, and by further increasing the integration of capital markets (Bris et al., 2004). Some have argued that improvements in financial integration in Europe prior to the introduction of the euro had already resulted in a lower cost of equity. More broadly, empirical evidence suggests that the ongoing process of financial globalisation has lowered the cost of equity, due to a decrease in the required expected return on equity and in agency costs for non-financial corporations raising external funds (Stulz, 1999).

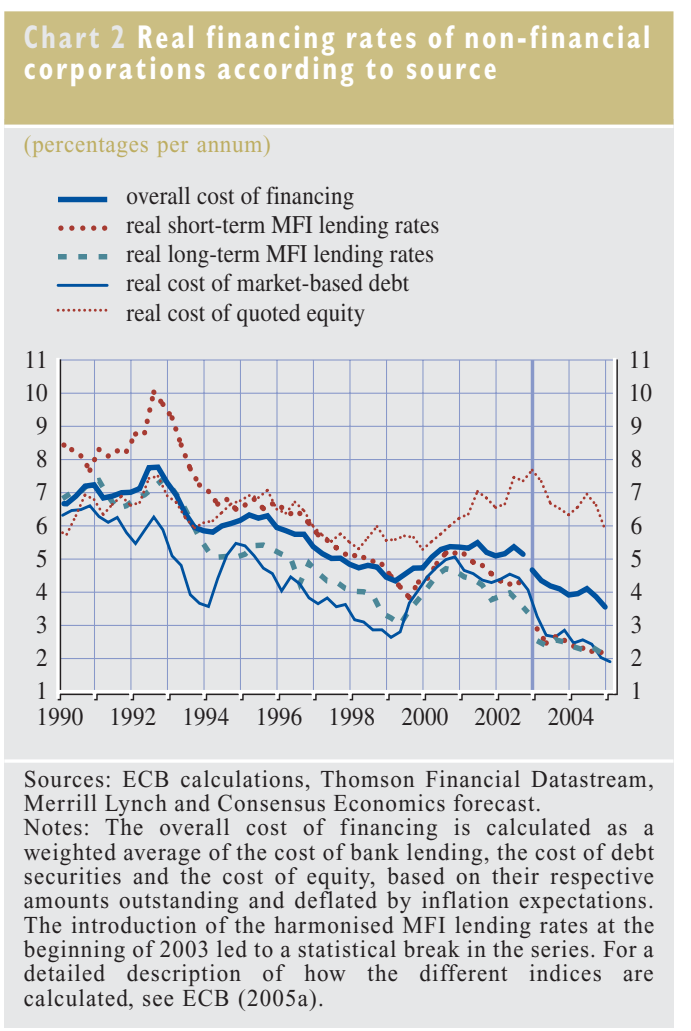

Chart 2 shows that over the past 15 years, the real cost of debt financing for non-financial corporations has come down quite significantly in the euro area, both for bank loans and corporate bonds, reaching historically low levels in 2004 and 2005. In parallel, the real cost of quoted equity increased significantly from 2000 until early 2003. This increase was directly related to the corresponding fall in stock prices owing to subdued earnings developments after the high expectations for the benefits of new technologies (the "New Economy") had been brought in line with economic reality. During the past two years up to the first quarter of 2005, the real cost of quoted equity declined somewhat but remained at relatively high levels compared with the real cost of debt financing. The overall cost of financing, as reflected by the composite indicator of the real cost of financing, has been on a downward trend since the early 1990s (see Chart 2), reaching near historic lows more recently. It is worth mentioning that the current weighting used to calculate the overall cost based on the amounts outstanding currently gives a large weight to the cost of equity, which has been substantially higher than the cost of debt financing in recent years. ${ }^{3}$

Among the different indicators available in the euro area, the Bank Lending Survey allows the analysis of the different elements of the credit cycle the lenders' perspective. ${ }^{4}$ In this regard, the Bank Lending Survey, addressed to credit officers in the banks, represents a unique set of information from the institutions at the centre of the monetary policy transmission process. It is therefore particularly interesting to examine the conditions and terms that banks apply to their credit policies. Chart 3 suggests that there has been a marked trend towards a loosening in credit conditions since the Bank Lending Survey was first launched in the last quarter of 2002.

\footnotetext{
3 Partly because of this, equity issuance has been relatively contained in recent quarters (see Section 3.4).

4 For more detailed information on the Bank Lending Survey,
} see Berg et al., 2005. 


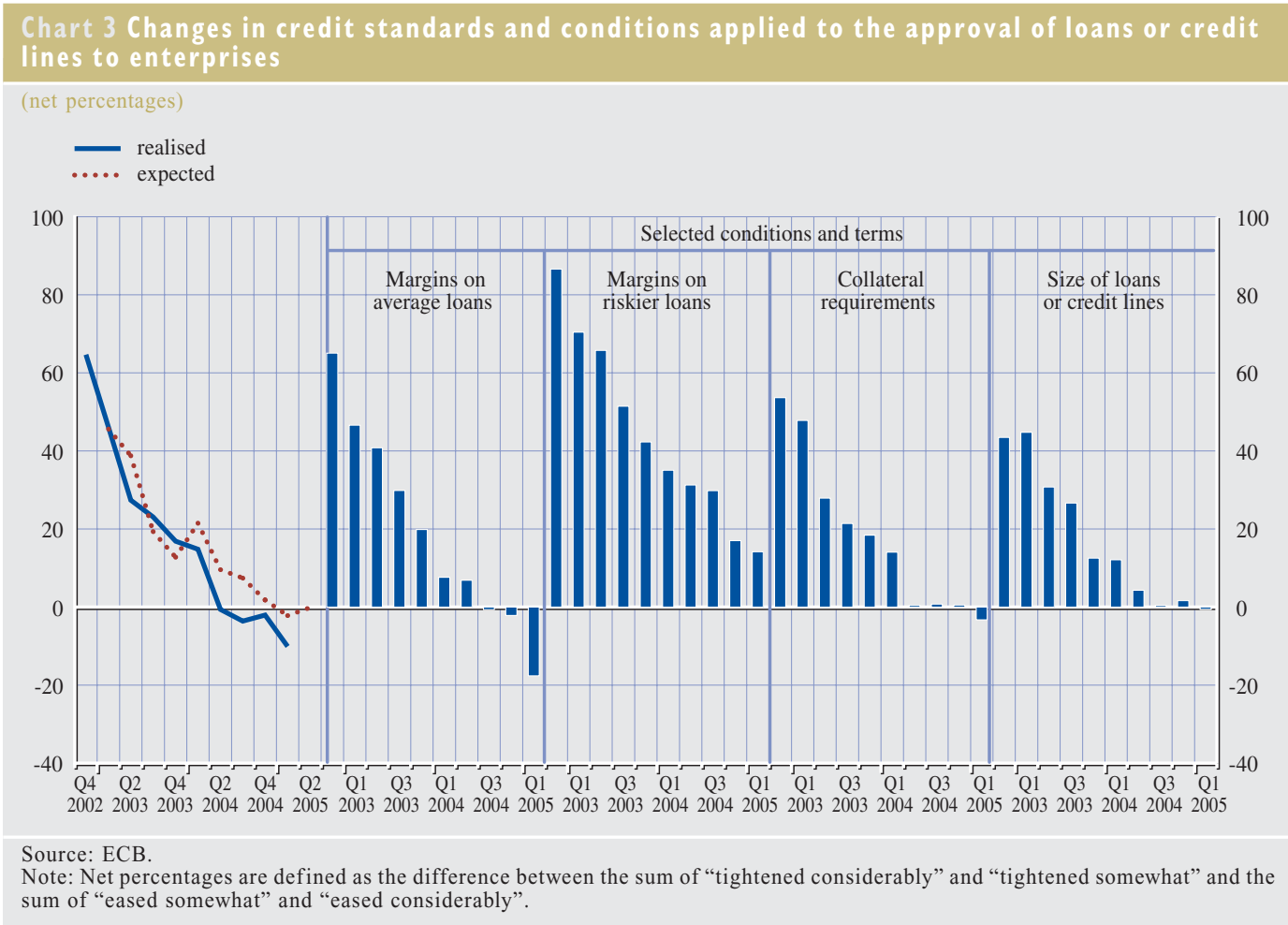

According to the respondent banks, this has been achieved mainly via declines in margins on average and, to a lesser extent, on riskier loans. Overall, margins on banks' lending rates are expected to depend on a number of factors, of which the role of credit risk and the conditions of the banking sector are particularly relevant. For this reason, bank lending spreads are considered in detail in Chapter 5, which analyses the impact of the banking sector in financing conditions. By contrast, the next section considers the role of corporate bond spreads in financing conditions.

\subsection{SPREADS ON CORPORATE BONDS}

As a complement to the real cost of external financing, the development of corporate bond rates with respect to developments in benchmark interest rates can provide insight into how the market assesses the credit risk premium faced by corporations when raising external funding. Corporate bond spreads also reflect other aspects, such as supply and demand factors, differences in liquidity and differences in tax treatment. ${ }^{5}$

One of the most important corporate bond spread indicators is the difference between the yields on corporate and government bonds, whereby the latter usually aim to proxy the so-called "risk-free" or "default-free" interest rate. For this indicator, several studies have analysed the determinants of spreads, particularly in the United States. In this regard, Elton et al. (2001) suggest that the spread between corporate and government bond yields in the United States can be partly explained by expected credit risk and taxes. Perraudin and Taylor (2003) show that, in addition to these factors, a liquidity premium is an important component of credit spreads. Finally, Huang and Huang (2003) find that credit risk accounts for only a fraction of the corporate/US

5 The specific factors that determine yield or credit spreads have been the topic of many theoretical and empirical studies (see, for example, Merton, 1974; Collin-Dufresne et al., 2001; and Perraudin and Taylor, 2003). 
Treasury yield spreads for investment-grade corporate bonds, but for a much higher proportion of yield spreads for below investment-grade or junk bonds.

With respect to the determinants of yield spread changes in the euro area, de Bondt (2002b and 2004) shows that the corporate debt-to-GDP ratio, stock prices and real shortterm interest rates are the major determinants of corporate bond spreads. Van Landschoot (2004) finds that the effect of the determinants of corporate bond spreads largely depends on the precise characteristics of the bonds, especially their specific rating, as bonds with lower ratings are affected more by economic and financial news. In addition, liquidity risk increases credit spreads significantly, particularly for lower-rated bonds, such as BBB bonds.

The spreads between interest rates on various private and public sector debt components can also offer information on economic and financial developments (see Duca, 1999). For example, by providing information on expected default losses, commercial paper and corporate bond spreads can signal in advance possible changes in the business cycle (e.g. Stock and Watson, 1989, Friedman and Kuttner, 1998; Hamilton and Kim, 2002 and de Bondt, 2004).

\section{Developments in corporate bond spreads}

Building on the literature indicated above, the ECB analyses the development of various interest rate spreads, mainly to provide an indication of how financial markets assess expected credit risk in different segments of corporate borrowers and rating categories. With regard to the latter, Chart 4 shows that the spreads on BBB-rated bonds and high-yield bonds increased sharply from 2000 onwards. There are various explanations for this, including a rising credit risk linked to the expected slowdown in economic activity, coupled with other factors, such as the September 2001 terrorist attacks in the United States and corporate accounting scandals. In 2003, however, rapid corrections in spreads

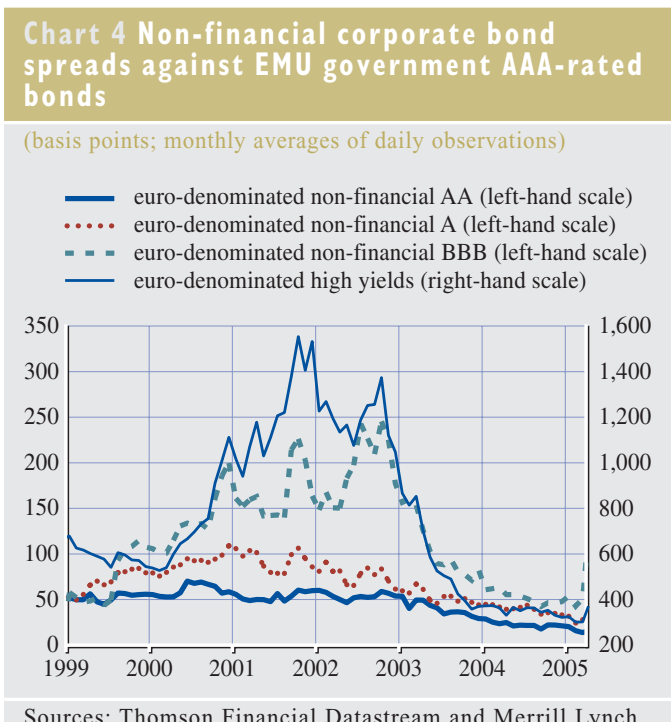

Sources: Thomson Financial Datastream and Merrill Lynch.

took place, given increasing market confidence and waning uncertainties, and in the course of 2004 , corporate bond spreads hit their lowest level since the introduction of the euro. This development may be partly attributed to the perception of relatively low credit risk in the euro area during this period. It may also reflect supply and demand considerations not directly linked to credit risk, such as relatively strong investor demand for higher-yielding assets in an environment of relatively low returns on alternative instruments.

\subsection{SOURCES OF CORPORATE EXTERNAL FINANCE}

Developments in costs are a key input into the analysis of developments of financial quantities. This section analyses the main components of corporate financing, i.e. loans granted by banks (including syndicated loans), the issuance of debt securities and the issuance of equity (see Box 2).

As discussed in Chapter 2, in a world of frictions (i.e. where the conditions set by Modigliani-Miller (1958) do not apply), recourse to different types of external financing influences both corporations' financing conditions and the real economy. In 
addition, when considering the actual capital structure of corporations, this analysis, in general, does not make strong initial theoretical assumptions. In fact, in line with Fama and French (2005), it is assumed that the main theories of the capital structure of the firms, namely the "trade-off" of capital structure and the "pecking-order" theories (see Chapter 2), are somewhat problematic as standalone theories. When trying to assess some aspects of financing decisions, it therefore seems warranted to consider them both as complementary ideas, with each containing elements of truth. This pragmatic approach seems to be supported in the bulk of recent empirical literature. ${ }^{6}$

\subsection{BANK LOANS}

The majority of bank loans to euro area nonfinancial corporations are loans with an initial maturity of over five years. Although there is no harmonised information about the purposes for which euro area non-financial corporations demand these loans, longer-term loans are predominantly used to finance the acquisition of capital goods. Shorter-term loans are used for a variety of purposes, notably the financing of working capital requirements. More recently, shorter-term loans have also been used as a form of bridge financing in financial acquisitions related to M\&A activity. Chart 5 shows the composition of bank loans to nonfinancial corporations by original maturity at the end of March 2005.

Owing to data limitations at the euro area level, as aggregate data on bank loans to nonfinancial corporations have only been available since 1997 for the euro area, the behaviour of bank loans to non-financial corporations within the euro area has been investigated in various studies at the national level. Equations on loan demand for individual euro area countries can also be found in the monetary and financial blocks of some national and multicountry macroeconometric models. For instance, De Bandt et al. (2001) model loans to non-financial corporations separately within the Banque de France quarterly model of the

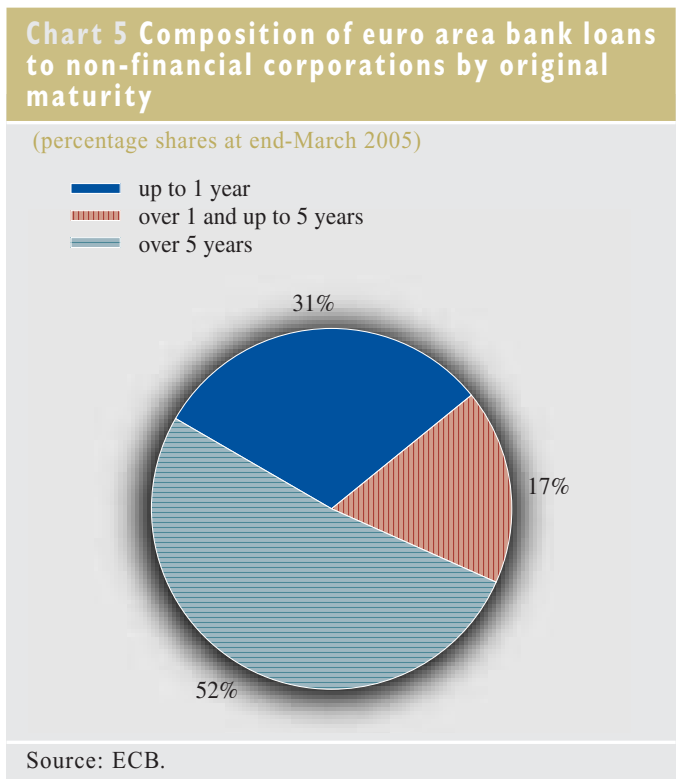

French economy. The Banca d'Italia's (1986) model of the Italian economy also includes one equation for total credit demanded by nonfinancial corporations, while De Nederlandsche Bank's model of the domestic economy comprises individual equations for both short-term and long-term credit demand from non-financial corporations (see Fase et al., 1992). At present, however, there is no evidence available for the euro area as a whole. ${ }^{7}$

\section{- Developments in bank loans}

Among the components of GDP, developments in loans to non-financial corporations are most closely correlated with those in non-residential investment. Chart 6 shows the historical behaviour of the annual growth rates of real loans (deflated by the GDP deflator) and nonresidential investment over the last two

6 An elaborate overview of this empirical research is presented in Paranque and Friderichs (1999) and Myers (2003), for example. The latter study concludes that "it appears that both the trade-off and pecking order theories are at work in real life. The economic factors that drive the theories - taxes, costs of financial distress and information asymmetries clearly are important. Yet each theory stumbles when asked to explain the financing of certain classes of firms" (Myers, 2003, p. 239)

7 Calza, Gartner and Sousa (2003) and Calza, Manrique and Sousa (2003) focus on total loans to the euro area private sector. 


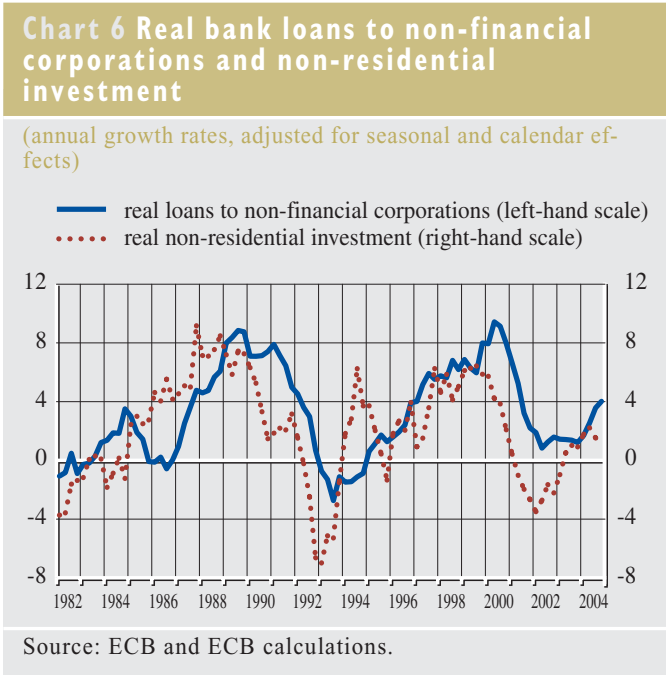

decades. Over the period considered, loans to non-financial corporations grew on average by about $3 \frac{1}{4} \%$ per annum, while investment growth averaged around 2\%. Loan growth seems to lag slightly behind developments in investment expenditure. Indeed, the correlation between loan growth and investment growth brought forward by one year is just under $80 \%$.

Box 3 assesses loan developments over recent years in the broader context of general economic activity and historical regularities. It is found that the deceleration in corporate loans seen over the past few years was not exceptionally strong, if compared with the rates reached in the previous period of economic weakness at the beginning of the 1990s. While the Box focuses on the link between these variables in recent years, Chart A graphically illustrates a long-term correlation between these types of loans and output. As expected, fast (slow) GDP growth tends to be followed by strong (weak) nonfinancial loan growth. In addition, Box 4 evaluates the development of a particularly sophisticated component of the overall credit market: the euro area syndicated loan market.

Looking in more detail at the last few years, the annual growth rate of real loans to nonfinancial corporations rose rapidly after the start of Stage Three of EMU, reaching a peak for the last two decades of $9.5 \%$ at end- 2000 (see Chart 6). While this strong pace of loan growth was partly driven by sustained investment growth and expectations, it also reflected increased financing needs from euro area non-financial corporations engaged in financial transactions. These transactions were related to intense M\&A activity, both within the euro area and overseas (mostly in the United States). Another factor that may have played a role in the demand for loans during that period was the rise in the funding needs of telecommunications companies taking part in UMTS licence auctions in several European countries.

After peaking in 2000, real loan growth followed a rapid downward trend throughout the following two years and has since stabilised at relatively subdued growth rates. While weak loan growth should not come as a surprise at a time of economic slowdown and increased uncertainty, the protracted period of weak growth prompted investigations into additional explanations. The effect of balance sheet improvements and debt restructuring on loan demand, as well as that of increased availability of alternative sources of finance, both internal and external, are worth mentioning in this context.

\section{Bo 3}

THE EFFECT OF BUSINESS CYCLE CONDITIONS ON THE DEVELOPMENTS IN LOANS TO NON-FINANCIAL CORPORATIONS IN RECENT YEARS

After growing, on average, at the exceptionally high rate of $9 \%$ between 1999 and the first half of 2001, the annual rate of growth of euro area bank loans to non-financial corporations declined considerably throughout the rest of 2001 and the first half of 2002. It subsequently 
stabilised around 3\%-4\% between mid-2002 and the first half of 2004, before recommencing an upward trend.

While a sharp decline in loan demand should not come as a surprise at a time of economic slowdown, this protracted period of subdued loan dynamics sparked the question as to whether the annual rate of growth of loans to non-financial corporations may have fallen to excessively low levels. The main concern in this regard was that, given the importance of bank loans for the financing of euro area non-financial corporations, weak credit growth - particularly, if reflecting reduced credit supply - could have hampered the strength and speed of the future economic recovery.

To answer this question, it is useful to put the developments in loans over recent years into the broader context of historical macroeconomic regularities. Chart A shows the annual growth rates of real loans to non-financial corporations (deflated by the GDP deflator) and real GDP between the first quarter of 1982 and the first quarter of 2005.

The chart suggests that when real GDP growth falls below its long-term average, real loan growth also tends to grow at below-average rates (with some exceptions, such as the mid1990s). This empirical regularity appears to have also held true during the period of economic weakness over the past few years. The chart also suggests that corporate loan growth tends to lag economic growth in the euro area, which implies that current loan developments might still reflect the effect of past subdued economic activity.

The cross-country analysis presented in Chart B also substantiates the effect of business cycle conditions on the developments in loans to non-financial corporations in recent years. The chart plots the average annual rate of nominal GDP growth between 2001 and 2003 against the average annual growth rate of corporate loans over the same period. There is an overall positive correlation between the growth of loans to non-financial corporations and economic growth. The chart also shows a relatively significant concentration of large countries at the lower end of

Chart A Bank real loans to non-financial corporations and real GDP

(annual growth rates)

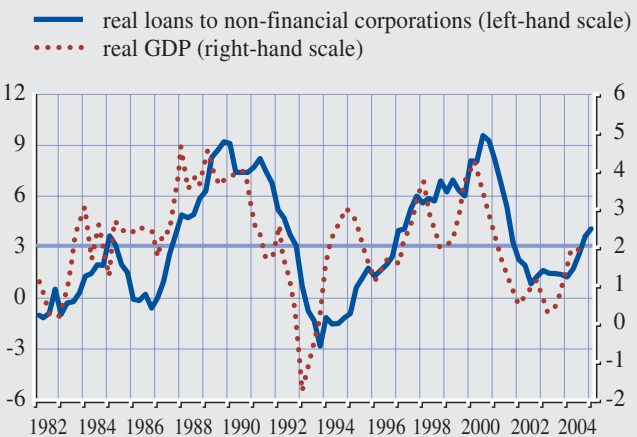

Sources: ECB and Eurostat.

Note: The horizontal line indicates the average rate of growth of real loans to non-financial corporations (deflated by the GDP deflator) and real GDP over the period Q1 1982 - Q1 2005 (3.3\% and $2.1 \%$, respectively). 
the interpolating line, indicating that the larger economies in the euro area have tended to experience both slower growth in nominal GDP and lower growth in loans to non-financial corporations.

It is important to bear in mind that the graphical analyses presented in Charts A and B do not take into account the effect of other variables that are likely to influence loan developments, notably the real cost of financing and substitution with other sources of external finance or internal funds. However, it does provide some preliminary indications that the business cycle may to some extent explain the relatively weak growth of loans by non-financial corporations that has been observed in recent years.

\section{Box 4}

\section{THE SYNDICATED LOAN MARKET IN THE EURO AREA}

An additional means of non-financial corporate lending is syndicated loans, which are concerted agreements among a group of banks to extend loans to corporate borrowers. These loans are often used as bridge financing in the arrangement or pre-financing of large corporate bond issues and in the financing of M\&As. The market for syndicated loans is very international, large and growing rapidly, registering annual growth rates of more than $20 \%$ during the 1990 s. Syndicated loan figures are of interest because, among other things, there is some empirical evidence that they probably have some leading indicator properties for bank lending in general (Gadanecz and von Kleist, 2003). Empirical evidence shows that loans are more likely to be syndicated as information about the borrower becomes more transparent, as the reputation of the managing agent of the syndicated loan improves, and as the maturity of the loan increases (Dennis and Mullineaux, 2000). It has also been demonstrated that syndicated loans in which the arranger of the loan retains a larger share have lower interest rates, as these loans appear less risky, and banks are able to differentiate between risky and less risky loans (Casolaro et al., 2003).

In line with the international development of the syndicated loan market, development of syndicated loans in the euro area has indeed been rather robust, particularly from the late $1990 \mathrm{~s}$ onwards (see Chart). This growth may have been driven by the risk-sharing characteristics of syndicated loans, which allow participating banks to share credit risk within the syndicate. The increase in mergers and the growth of the corporate bond market in the euro area have also been contributory factors. Looking at the decomposition according to financing purposes, growth in syndicated loans used to fund M\&As has declined over the past few years, a trend which should be seen in the light of the continuing relatively low level of M\&A activity in the euro area.

\section{Euro area syndicated credits by type of} purpose

(€ billions: 12-month moving sums)

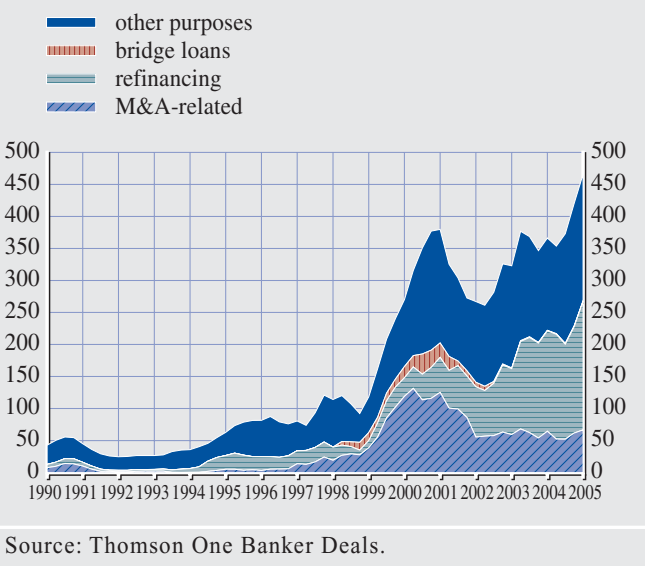




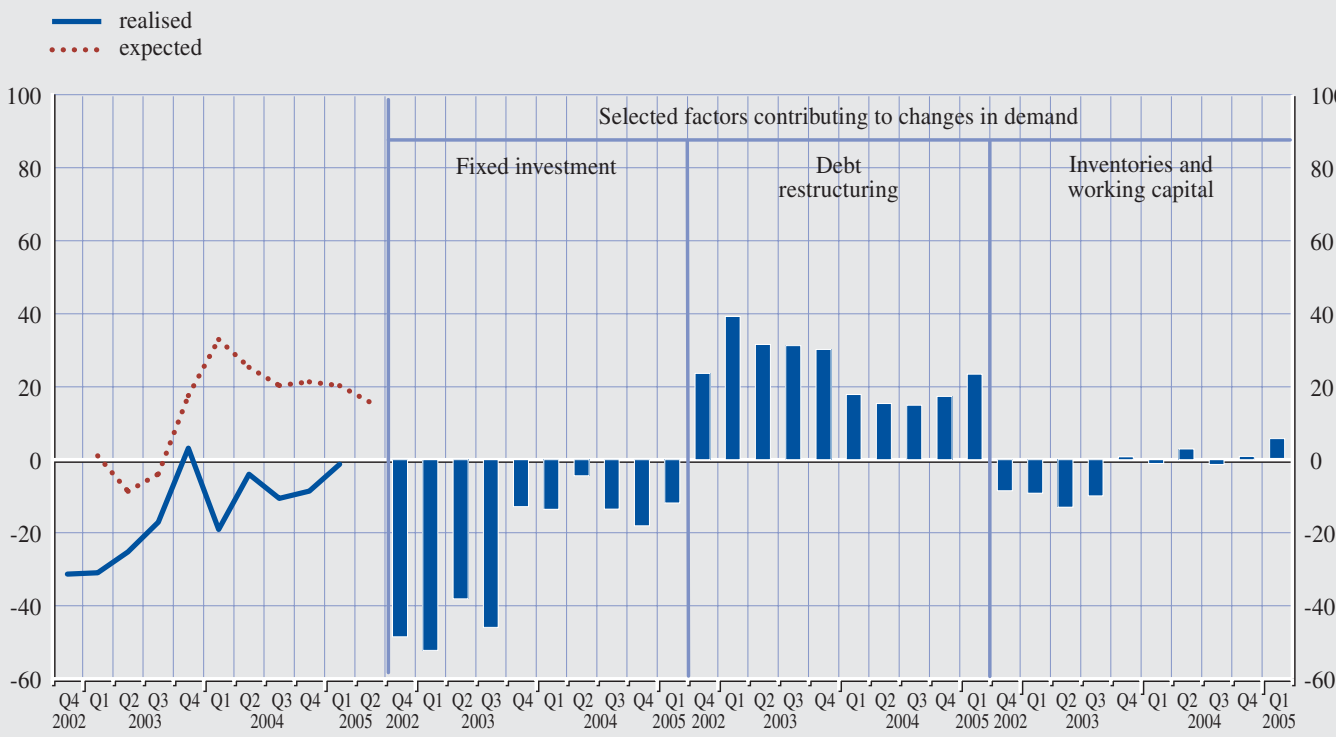

Source: ECB.
Note: "Net percentages" are defined as the difference between the sum of "contributed considerably to higher demand" and "contributed somewhat to higher demand" and the sum of "contributed somewhat to lower demand" and "contributed considerably to lower demand".

In addition, the Bank Lending Survey could also be useful in trying to disentangle the supply and demand factors that underlie credit developments. Overall, Chart 7 suggests that, in net terms, loan demand has still been relatively subdued (although there are some signs of improvement compared with the last quarter of 2002 when the survey was launched). Banks are also asked about the various factors that underlie movements in loan demand. In this regard, weak fixed investment continues to be a major contributory factor to the overall negative net demand, whereas debt restructuring seems to be a significant contributory factor to positive net loan demand.

\subsubsection{DEBT SECURITIES}

Alongside loans provided by banks (including syndicated loans that are provided by groups of financial intermediaries), the other main part of debt financing by non-financial corporations is the issuance of debt securities. As indicated in Chapter 2, a broad and deep corporate debt securities market opens up a viable alternative avenue of finance for corporations. ${ }^{8}$ In general, a firm's decision to issue debt securities is driven, beyond its overall demand for funds, by a number of considerations, including taxes, bankruptcy rules, and agency and asymmetric information costs. In this regard, de Bondt (2002b and 2005b) shows that since the introduction of the euro, the debt securities market has been tapped by non-financial corporations to fund their M\&A, investment or working capital financing needs. It is also shown that substitution between debt securities issuance and other sources of corporate finance takes place: the supply of debt securities by non-financial corporations is sensitive to the cost of debt securities vis-à-vis other sources of corporate finance, and the spread between long and short-term interest rates is relevant for the

8 The presence of a well-functioning (corporate) bond market may enhance the welfare of savers, who may use it for investment purposes. More savings may therefore be mobilised in the financial system to fund investment (Herring and Chatusripitak, 2001). 
mix between long and short-term debt securities. De Bondt and Marqués Ibáñez (2004 and 2005) investigate the development of the high-yield corporate bond market in the euro area from the perspective of the diffusion of financial innovations, i.e. the launch of a new financial product. They find that the development of the high-yield segment of the euro area corporate bond market has also been affected by corporate financing needs.

\section{- Developments in corporate debt securities}

The issuance of debt securities by nonfinancial corporations in the euro area in general, and the development of the corporate bond market in the euro area in particular, have been buttressed by the introduction of the euro and the start of the single monetary policy with Stage Three of EMU in 1999 (see Santillan et al., 2000). Overall, the more competitive environment brought about by the introduction of the euro has been a major driving force behind the structural development of the eurodenominated bond market since the late 1990s (ECB, 2001). The amount outstanding of eurodenominated debt securities issued by nonfinancial corporations has grown at an average annual rate of about $15 \%$ from January 1999 to 2004 , which is significantly higher than the $2 \%$ average annual growth rate for this sector

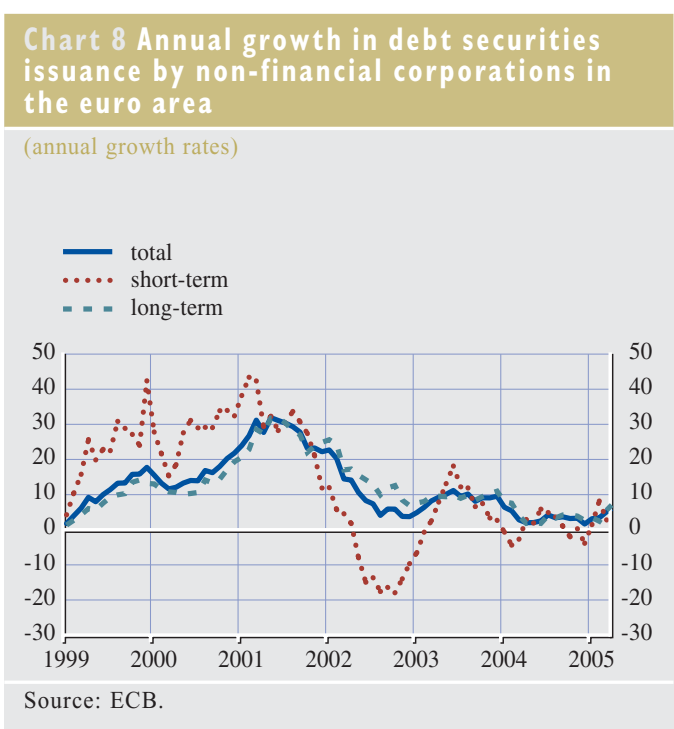

during Stage Two of EMU (see Chart 8). However, the figures also show that the annual growth rate of debt securities issuance by nonfinancial corporations started to decline towards end-2001 and remained at lower levels in the subsequent years too. This may have been due to a number of factors, three of which can be identified as the main ones (see De Bondt, 2005b). First, in 2002, the overall slower growth in debt securities issuance by non-financial corporations took place in an environment of reduced needs for working capital financing, in combination with relatively high debt levels and growing investor concerns about credit risk. The latter was reflected in the deteriorating corporate financing conditions, as corporate bond spreads at the lower end of the credit quality spectrum were widening considerably (see also Chart 4). Second, in 2003 and especially in the course of 2004, improvements in corporate profitability may have facilitated the consolidation of corporate debt. Third, the annual growth figures for debt securities issuance by non-financial corporations are somewhat distorted by the very high level of issuance activity in a small number of sectors in 2001-02. During this period, the strong increase in corporate debt issuance was concentrated in the TMT (telecommunications,

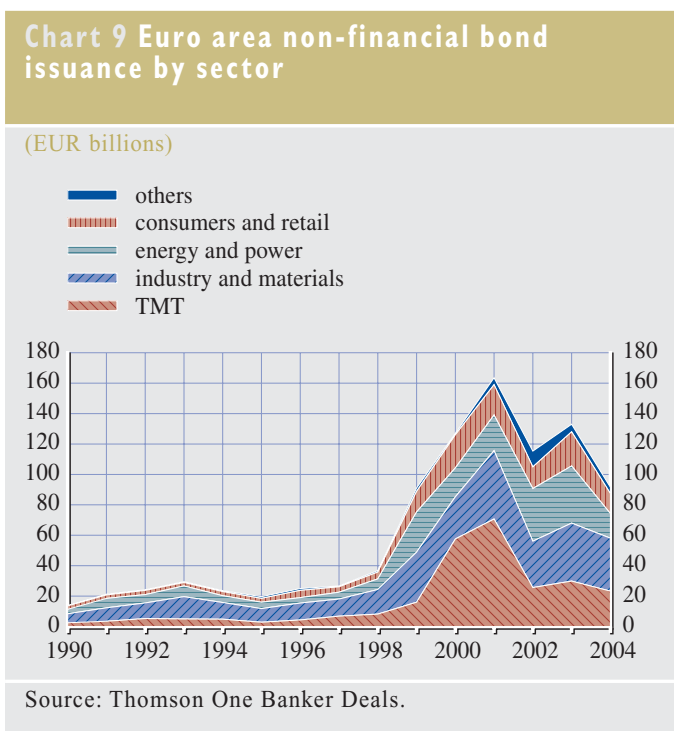


activity and the need to finance UMTS licences. When this exuberant issuance activity became more subdued in the following years, annual growth rates of debt securities issuance fell. More recently, however, debt securities issuance by non-financial corporations has recovered somewhat, which is likely to be linked to the continued very low cost of financing via debt securities, as well as a degree of normalisation after the high redemptions in 2004 (see Chart 9).

\subsubsection{EQUITY ISSUANCE}

There are two types of equity issuance: companies can either issue shares for the first time and obtain a listing on a stock exchange or, if they are already listed, they can issue additional shares that are perfect substitutes for the existing shares. The first type is called an initial public offering (IPO), while the second type is called a secondary public offering (SPO) or a seasoned equity offering (SEO). There is much literature on both forms of equity issuance, and a number of empirical patterns have been documented (see, for instance, Ritter, 2003a). In this regard, there is substantial evidence of strong market cycles in IPOs, i.e. pronounced cycles in the number of IPOs per month and in the average initial return per month (see, for example, Lowry and Schwert, 2002). This is further supported by the fact that the volume of IPOs fluctuates considerably over time. These so-called "hot" and "cold" markets may be caused by fluctuations in the demand for capital by nonfinancial corporations and investor sentiment (Ritter, 2003a).

From a microeconomic perspective, it has been argued that the likelihood of an IPO increases with the size of the company and the industry's market-to-book ratio. Furthermore, it seems that non-financial corporations obtain listings not to finance future investments and growth, but rather to rebalance their accounts after periods of high investment and growth, i.e. to rebalance their debt-to-equity ratio. This appears to be supported by the fact that IPOs reduce the cost of debt of issuing companies (Pagano et al., 1996 and 1998).

There are several studies that investigate various aspects of IPOs in the United States and, to a lesser extent, in some individual European countries. These are beyond the scope of this Occasional Paper (see, for example, Ritter, 2003a and 2003b), but some recent findings can be summarised as follows. A number of US empirical articles have shown that issuing firms may practice "equity market timing", implying that non-financial corporations will issue shares at high prices and either repurchase them or turn to internal finance or debt financing when prices are low (Hovakimian et al., 2004). Moreover, Ritter (2003b) shows that in the period 1999-2001, Europe witnessed record volumes of IPOs coupled with record underpricing, partly driven by hopes of substantial gains from new technologies. Many of these IPOs can therefore be characterised as "New Economy" offerings (see Schuster, 2003, and Ljungqvist and Wilhelm, 2003). In fact, during this period, in addition to the privatisation of a number of (partially) state-owned companies, there were many new company listings, particularly in the TMT sectors. This was also linked to the spectacular growth around that time of specialised stock markets for so-called growth companies, which became a thriving market segment for the issuance of quoted shares. ${ }^{9}$

The market capitalisation and the number of listed companies in the so-called EURO.NM market - a pan-European group of five exchanges providing equity capital for new and high-risk companies - increased rapidly from 1998 to 2000 . However, with the collapse of the "dot-com" bubble, the EURO.NM market ceased to exist in December 2000, and Frankfurt's Neuer Markt closed down in 2003.

9 In general, equity financing is particularly advantageous and essential for the financing of innovative firms, as the risk profile of these firms can make banks reluctant to provide loans. Thus, for these new and high-risk firms, financing through specialised stock exchanges could be of particular importance (Bottazzi and Da Rin, 2002). 
Schuster (2003) finds that the positive IPO returns in seven European countries in the period 1988-98 (i.e. the whole sample period) were driven by the relative outperformance of these "New Economy" IPOs. Schuster also reports considerable underpricing, but does not find evidence of any long-run underperformance for the whole sample. Regarding the latter, underperformance is expected if investors assume that companies will only issue shares if they believe that their existing shares are overvalued, i.e. that their price is too high from a fundamental value perspective.

\section{Developments in equity issuance}

The actual gross issuance of equity over the past five years in the euro area is shown in Chart 10. The so-called "New Economy" or "dot-com" bubble of 1999-2001 is clearly visible, for both IPOs and SPOs. It can also be observed that from the second half of 2003 to the beginning of 2005, the amount of gross equity issuance in the euro area started to increase again.

For a correct assessment of the development of financing conditions, however, the net amount of equity issued is a more relevant indicator than gross issuance, as non-financial corporations may buy back or delist some or all

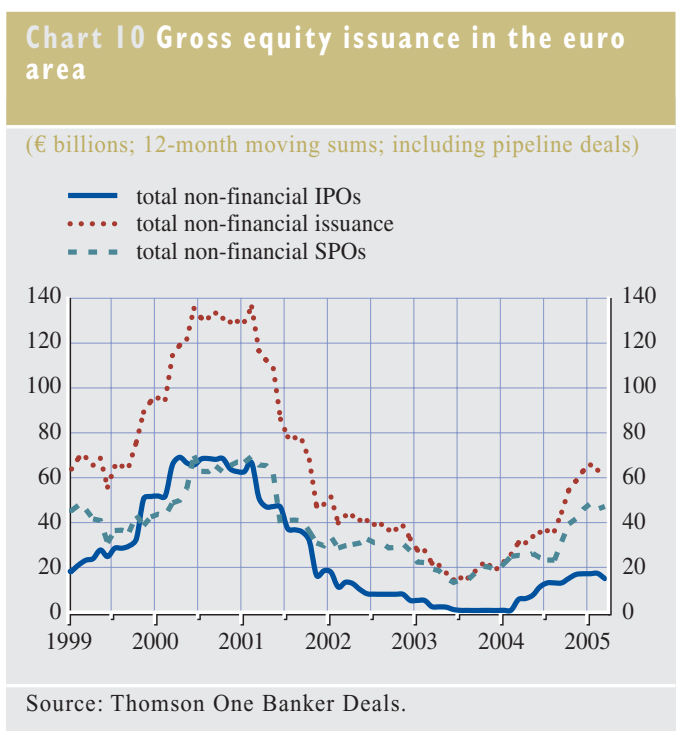

of their shares issued, which of course affects their financial position. Chart 11 therefore shows the annual growth rate of the net issuance of quoted shares by non-financial corporations in the euro area. It is clear that, after the "dot-com" bubble, net equity issuance in the euro area remained subdued and stabilised at a relatively low level. Again, it has to be mentioned that comparisons with historic developments in equity issuance are somewhat misleading, as the high level of equity issuance, particularly during the period 1999-2001, was heavily influenced by extremely buoyant issuance in the TMT sectors, which resulted in high annual growth rates during that period.

The relatively subdued issuance of net equity in the euro area from 2002 to early 2005 may partly reflect modest investor demand and the relatively high cost of equity, as Chart 2 illustrates. The low issuance of quoted shares probably reflects the limited need for external financing sources at that point in the economic cycle. In addition, euro area companies, to some extent, may also have made use of other alternative sources of finance, such as mezzanine finance and private equity. As a more structural development that could explain the continuing sluggish growth of net equity issuance in the euro area, evidence suggests

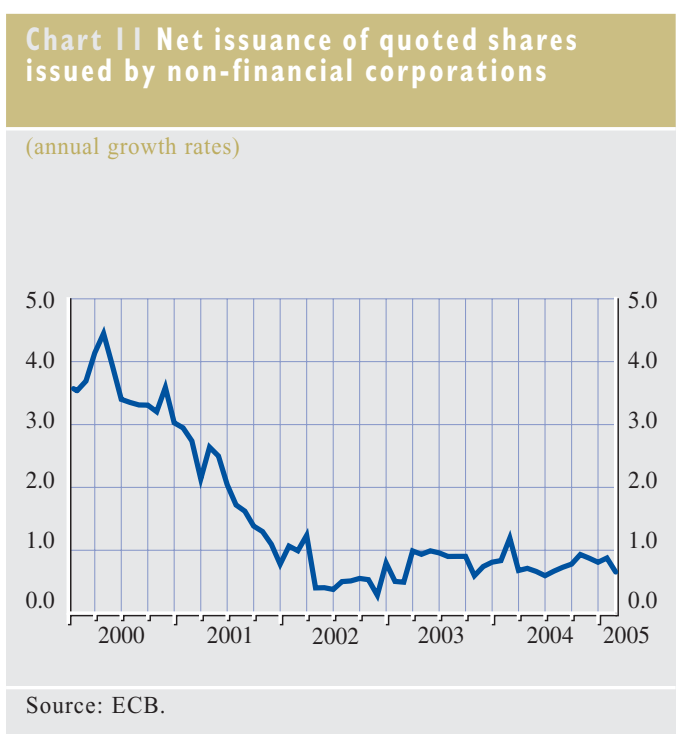


that in the course of 2003 and 2004 the delisting of stocks exceeded the actual listing of stocks, contributing to an overall decline in the net issuance of equity. Four factors support this assertion. First, the rate of privatisations of public companies slowed down considerably, mitigating the overall number of IPOs. Second, private buy-outs, mergers and takeovers reduced the amount of outstanding quoted shares. Third, the number of European acquisitions of US companies, which were often financed by the issuance of new shares, fell significantly. And fourth, anecdotal evidence suggests that a significant number of companies initiated share buy-back programmes. All in all, these factors amounted to a considerable redemption of quoted equity, thus reducing actual net issuance.

\subsection{BALANCE SHEET POSITION OF NON-FINANCIAL CORPORATIONS}

As indicated in Chapter 2, the way monetary policy impulses are transmitted to borrowers is largely determined by their own balance sheet position. Likewise, borrowers' ability to take on additional debt depends predominantly on their actual and expected financial situation. The balance sheet position is linked to the financing cost of companies through the risk premium paid by borrowers to cover the perceived risk of default. In this regard, the risk premium typically reflects the perceived development in the net worth of companies, i.e. the sum of all assets minus debt liabilities. ${ }^{10}$

The ECB monitors three main types of indicators of the balance sheet situation of nonfinancial corporations in the euro area, namely financing gaps, leverage ratios and debt service burden indicators.

The financing gap - which is referred to as net borrowing in ESA95 (European System of Accounts 1995) - is defined as the difference between the gross saving and the gross capital formation of non-financial corporations. ${ }^{11}$ This indicator therefore reflects the need for external financing of non-financial corporations. While this indicator constitutes a useful synthetic measure of possible financial imbalances, interpreting it as a stand-alone measure may often be difficult. For instance, a high financing gap may be compatible with either very favourable investment prospects (possibly linked to high profit expectations), or to insufficient internal saving.

The definition of the financing gap can be extended by adding the financial investment to the gross capital formation of non-financial corporations in order to take account of the rise in the importance of financial transactions in most developed countries in recent years (see Jaeger, 2003). However, such an extended ratio may be inflated by the development of certain financial transactions that have no, or a limited, effect on the actual net indebtedness of companies as a whole. For example, intercompany loans within a group, or M\&As settled via the exchange of shares among merging partners, could inflate both the financial assets and liabilities of companies without creating effective financing needs for the consolidated sector as a whole. ${ }^{12}$

The financing gap is a measure based on flows that reflects the current financial imbalance. This measure can be complemented by stock measures that reflect the accumulation of past financing flows, such as the debt ratio. The debt

10 The definition of net worth applied here refers to the one in use in the US flow of funds (Teplin et al., 2004). Note that this definition differs from the European System of Accounts 1995 (ESA95) to the extent that the liabilities taken into account in the derivation of the net worth according to ESA95 include not only debt but also equity liability.

11 More precisely, the net borrowing is equal to gross saving plus net capital transfers (for instance, capital subsidies) minus gross capital formation. Gross capital formation is defined as the sum of gross fixed capital formation, the change in inventories and acquisitions less disposals of valuables (Eurostat, 1996). In practice, statistics show a difference (or "adjustment") between the financing gap (net borrowing) in the non-financial accounts and the net borrowing in the financial accounts.

12 This problem arises due to the fact that the euro area annual financial accounts are in principle non-consolidated. For instance, the cross-holdings of shares between two companies, or cross-border inter-company loans, are in principle not netted out. In other countries, such as the United States, the flow of funds statistics net out most of these financial transactions (Teplin et al., 2004).
3 EXTERNAL

FINANCING OF NON-FINANCIAL CORPORATIONS 
ratio is an indicator of financial imbalance in the sense that excessive debt and related debt servicing obligations may lead companies to scale back investment plans, particularly if they experience unexpected and significant downward realignments of profit expectations, or upward movements in interest rates. One statistical advantage of the debt ratio is that it is constructed on the basis of relatively frequent, timely and harmonised statistics (whereas interest payments or financing gaps, for instance, are only available, at a macroeconomic level, on an annual basis). ${ }^{13}$

The aggregate measure of debt adopted by the ECB is defined as the sum of debt securities, loans and pension fund reserves. Some aspects of this definition are worth considering in more detail. First, this definition does not include other accounts payable (such as trade credit) since the quality of such statistics may be deemed problematic, and also because trade credit often takes place between two nonfinancial corporations, and in such cases, does not constitute a liability for the sector as a whole. ${ }^{14}$ Second, the debt aggregate based on euro area annual financial account data is only partially consolidated in the sense that crossborder inter-company loans within the euro area are not netted out. Third, this definition of debt includes elements such as the pension fund liabilities of companies, which represent the accumulation of funds by companies to cover future retirement payments to employees. These constitute quite specific liabilities often with very long-term maturities, which could also be excluded from alternative definitions of debt. ${ }^{15}$

The denominator side of debt ratios includes either GDP, or more accurately a measure of earnings, such as the gross operating surplus. ${ }^{16}$ (There is currently no quarterly indicator available at the euro area level that includes a broader measure of earnings, such as the debt to gross saving ratio $^{17}$ ).

The debt to financial assets ratio takes into account, in particular, securities included on the asset side of corporations that could potentially be used by companies for liquidity purposes or as collateral for loans granted. A comprehensive debt to total (financial and tangible) assets ratio, or an aggregate net worth indicator (i.e. total assets minus debt), cannot be constructed at the euro area level due to the lack of official series on the capital stock of companies.

Nevertheless, an indicator based indirectly on the net worth may be derived from the debt-toequity ratio. This ratio relates the debt of nonfinancial corporations to the market value of the companies, which, in a perfect and transparent market, should closely match their net worth. As a caveat, it should be borne in mind that the market valuation of non-quoted shares may be problematic, and may currently differ across euro area countries. In addition, the holdings by non-financial corporations of shares issued by non-financial corporations are generally not consolidated (or netted out) in the euro area financial accounts, so that the debtto-equity ratio may vary in line with changes in share cross-holdings among euro area nonfinancial corporations.

The interest payment burden is defined as the ratio of (gross or net) interest payments to the

13 However, for bank loans, a monthly interest payment proxy can be calculated as the average interest rate on bank loans to non-financial corporations (available in the MFI interest rate statistics statistics) multiplied by the corresponding stock.

14 Note that there is a case for monitoring trade credit developments in themselves, particularly at the micro level. A measure of trade credit activity may be informative, as movements in trade credit may contain information on business cycle developments and monetary transmission effects.

15 This item represented $8 \%$ of the debt of euro area nonfinancial corporations in 2004, (source: euro area quarterly financial accounts).

16 The gross operating surplus is defined as the difference between the value added and the compensation of employees and other taxes on production (see Eurostat, 1996). Note that, in the absence of quarterly series of gross operating surplus for non-financial corporations alone by Eurostat, a proxy is used by rescaling the series of gross operating surplus of the euro area economy based on data on the gross operating surplus of non-financial corporations in annual financial account data.

17 Gross saving of corporations equals gross operating plus net social transfers, net property income, taxes on income and wealth, and other current transfers. Gross saving data can be extracted from annual national non-financial account data. 
gross operating surplus of corporations. An extended measure of the interest payment burden, including repayment of the principal, provides additional information on possible liquidity and/or short-term financing constraints faced by companies. ${ }^{18}$

Before describing the developments in the balance sheets of non-financial corporations in recent years, it should be noted that the indicators presented so far are all macroeconomic measures. These allow the identification of major macroeconomic trends and risks, but it may mean that other significant factors are overlooked, such as the size or the sector of companies (see Hernando and Martinez-Carrascal, 2003).

\section{Developments in the balance sheet position of non-financial corporations}

The indebtedness of non-financial corporations increased considerably in the euro area from 1998 to 2001 (see Chart 13), broadly catching up with US levels (see Chart 12). This rise in corporate debt was only partially attributable to the size of the financing gap in this period which was not exceptionally large by historical standards (see Chart 14). One major factor behind the rise in corporate debt was the financing of sizeable M\&As and UMTS licences (see Section 3.4), in a context of

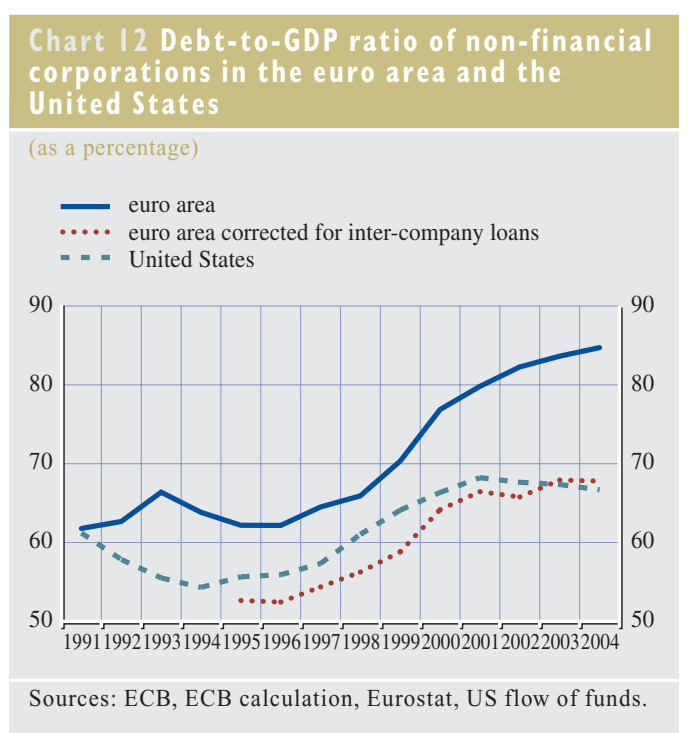

historically low interest rates. The debt to market value of companies followed a more volatile pattern, increasing significantly up to 2002, before subsequently receding.

The leverage ratios of non-financial corporations have improved slightly since 2002. This is in line with a rise in earnings and a moderation in the demand for credit, reflecting efforts made by non-financial corporations to restore their balance sheets. The improvement in equity prices also helped to enhance the companies' financial position. Overall, the debt to operating surplus ratio has remained broadly stable since 2002, whereas the debt-toequity ratio declined markedly with the rise in equity prices (see Chart 13).

Despite this improvement in recent years, corporate debt levels have been relatively high, for several reasons. First, the rise in corporate debt from 1998 to 2001 was extensively used to finance M\&As (and UMTS licences), and the repayment of such loans has been only gradual. This is all the more true in the case of large companies and certain sectors (e.g. the

18 In the absence of data on gross repayment flows, euro area estimates on repayment flows are used based on assumptions on the duration of the debt of non-financial corporations, derived from data on the structure of the outstanding debt of non-financial corporations, split by maturity.

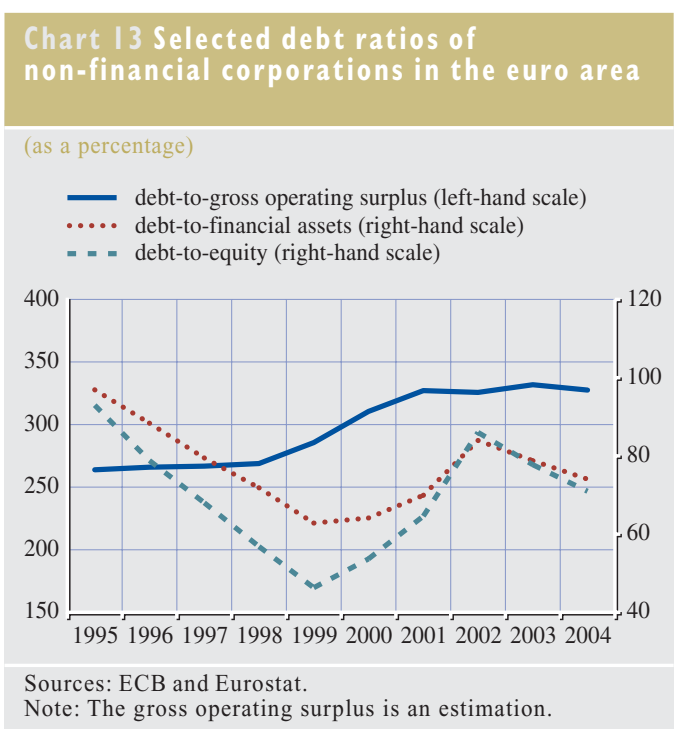




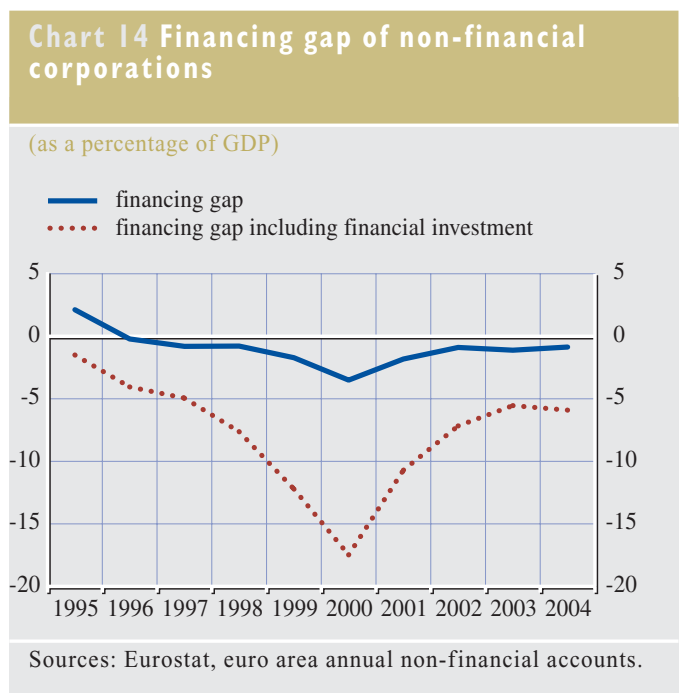

telecommunications sector). Furthermore, the low interest rate environment prevailing since the mid-1990s has increased the sustainability of corporate debt. In fact, the interest payment burden of non-financial corporations declined significantly in the first half of the 1990s, and has stabilised at relatively low levels (see Chart 15). Finally, capital losses incurred by some companies on their financial acquisitions of the late nineties might have contributed to slowing down debt consolidation processes.

\section{4}

\section{EXTERNAL FINANCING OF HOUSEHOLDS}

\section{I INTRODUCTION}

As discussed in Chapter 2, the literature on monetary policy transmission has focused more and more on the household sector in recent years. The importance of this sector has indeed been increasing over the last decade: bank loans to households represented around $47 \%$ of total outstanding bank loans to the nonfinancial private sector in the euro area in the early 1980s (on the basis of estimations) and $54 \%$ by 2004 . This increase has been evident since 1998, mainly due to the particularly strong rise in loans for house purchase.

This dynamic trend appears to have been caused by a number of macroeconomic factors,

\section{Chart I 5 Net interest payments of non-financial corporations}

\section{(as a percentage of gross operating surplus)}

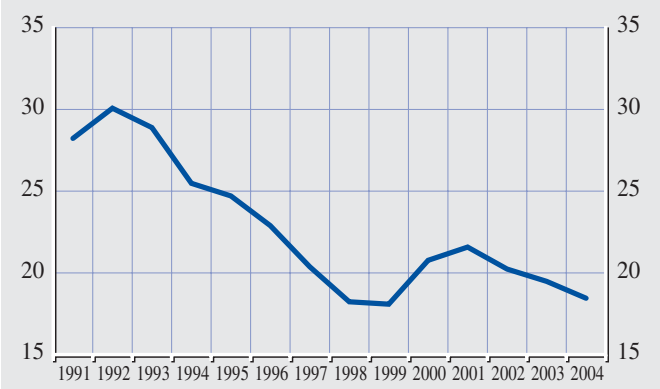

Sources: ECB, Eurostat, euro area annual non-financial accounts.

Note: The gross operating surplus is an estimation.

including the decline in interest rates as a result of the introduction of the euro, the steady growth in real estate prices and the increase in employment rates in several euro area countries. Other factors may also have influenced the demand for loans, but these are at present difficult to quantify, for example, changes in the features of mortgage contracts (such as an extension of the duration of contracts in some countries) $)^{19}$, tax or regulatory measures as well as demographic changes.

Overall, household debt in the euro area has risen sharply since 1998 , but is still below that in other industrialised countries such as the United States, Japan or the United Kingdom. Nevertheless, the degree of financial risks faced by households has been rising, particularly because of the enhanced sensitivity of households to changes in interest rates. Such risks seem relatively concentrated in euro area countries as well as across categories of households, which requires close monitoring (and further data collection) at the national level.

19 Extending the duration of loans may have been a way to keep monthly instalments broadly stable in the face of a rise in the nominal amount of loans taken (also against the background of the overall rise in house prices in some countries in recent years), also considering the reduction in bank lending rates. 
This chapter reviews the various indicators that the ECB monitors in order to assess households' financing conditions in the euro area. It starts by considering developments in the cost of financing faced by households (Section 4.2). It then elaborates on the developments in the demand for loans by households, and how such developments can be related to the evolution of economic fundamentals, such as economic activity and interest rates (Section 4.3). Finally, it addresses the interrelation between financing and the balance sheet position of households (Section 4.4).

\subsection{COST OF EXTERNAL FINANCE}

Interest rate levels can influence households' economic behaviour significantly. However, those interest rates that influence households' investment and saving decisions are not the risk-free interest rates underlying the yield curve but, rather the interest rates set by financial institutions on the different lending maturities. In turn, the level of lending rates to households depends on a number of factors, such as the level of risk-free interest rates, the type of mortgage contract (ECB, 2004c), its maturity, the level of perceived credit risk, collateral values and the state of the banking sector (see Chapter 5).

From a historical perspective (Chart 16), the real cost of mortgage borrowing in the euro area declined significantly from almost $8 \%$ in 1990 to around $3.5 \%$ in the first half of 1999 , bolstered by a significant decline in inflationary expectations. After picking up slightly in late 1999 and 2000, mortgage interest rates continued their downward trend from the third quarter of 2000 to early 2005 .

Rates on consumer lending have followed a similar decline to that of mortgage rates. Indeed, seen from a long-term perspective, interest rates on consumer credit have declined, dropping from a peak of around 10.5\% in 1992 to around $5.7 \%$ in early 2005 .

\section{Chart I 6 Bank lending rates for loans to households}

In terms of levels, the interest rates on consumer credit are consistently higher than those on mortgage loans, as residential mortgages traditionally bear less credit risk than consumer credit. This is because mortgage loans tend to be collateralised by the value of the underlying home, whereas consumer credit is often not collateralised, or the value of the underlying collateral (such as cars) tends to decline more rapidly over time. Finally, interest rates on consumer credit tend to respond more sluggishly to changes in the underlying market interest rates than mortgage interest rates, probably because competition in the mortgage loan market is more intense. A partly related phenomenon is the traditional stickiness of interest rates in some consumer credit segments, such as interest rates on bank credit cards (Sinkey, 2001).

\subsection{SOURCES OF HOUSEHOLDS' EXTERNAL FINANCE}

The household sector is mainly financed via bank loans, which accounted for an estimated $90 \%$ of total loans granted to households in 


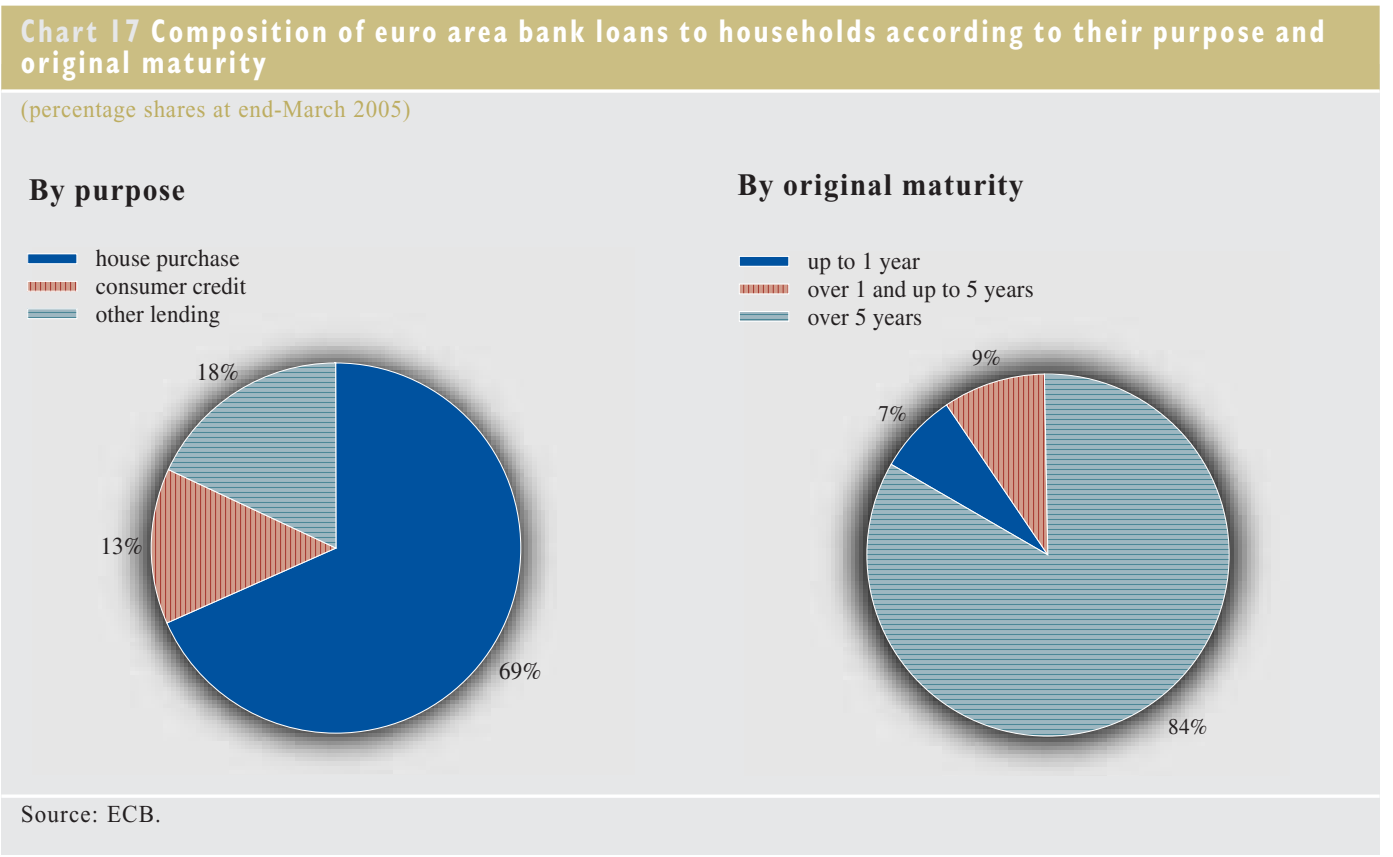

March 2005..$^{20}$ The remaining share is accounted for by loans from non-MFIs (such as some non-banks specialised in consumer credit, or special financial vehicles involved in securitising mortgage loans), although these are quantitatively relevant only in a small number of euro area countries. ${ }^{21}$

The majority of bank loans to households (around two-thirds of all bank loans to the household sector) are for house purchase. The rest is accounted for by "consumer credit" (i.e. loans for personal consumption of goods and services), and by the residual category "other loans to households" (i.e. loans to family businesses, for educational purposes, among others). Reflecting their composition according to their purpose, the large majority of loans to euro area households are of a longterm maturity, more specifically loans that have an initial maturity of over five years. Chart 17 shows the composition of bank loans to households according to their destination and maturity.

When analysing loans to households, a core angle of analysis consists of assessing whether they are in line with the values implied by the fundamental determinants of the demand for loans, such as disposable income, interest rates and housing prices, or whether, other factors may be at work. ${ }^{22}$ In this regard, a preliminary (and admittedly simple) empirical method of analysing developments in loans to households is to compare them with their long-term average growth rates. $^{23}$ This enables an assessment of whether conjunctural loan developments deviate significantly from

20 Proportion based on the ECB monetary statistics data for bank loans and the euro area quarterly financial accounts for total loans to households. Note that these numbers do not account for foreign loans to households, for which no data are currently available at the euro area level. Loans from foreign banks to euro area non-banks (including nonfinancial and financial corporations) represented around $4 \%$ of loans taken by households and non-financial corporations with financial corporations. (Source: BIS data, regularly reported in Table 3.2 of the ECB Monthly Bulletin).

21 See ECB (2003c) for a detailed description of the structure of debt financing by the household sector.

22 Empirical literature provides evidence that protracted periods of excessively fast credit growth can provide early indications of the building-up of financial imbalances and, ultimately, of macroeconomic instability (for a survey, see ECB, 2004a).

23 A more formal method of assessing whether the behaviour of loans is in line with their macroeconomic fundamentals would be to compare loan developments with the values predicted by an econometric model, such as that of Calza, Gartner and Sousa (2003). 
Chart I 8 Real euro area bank loans to households and GDP

(annual growth rates; adjusted for seasonal and calendar

real loans to households (left-hand scale) real GDP (right-hand scale)

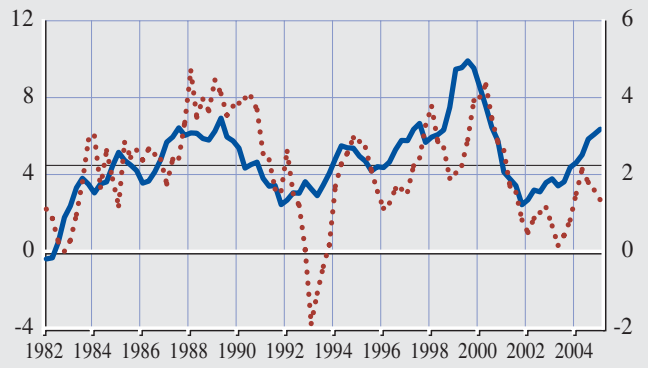

Sources: ECB, Eurostat and ECB calculations.

Note: The horizontal line indicates the average growth rate of real loans to households (deflated by the GDP deflator) and real GDP over the period Q1 1982-Q1 2005 (4.7\% and 2.1\%, respectively).

historical regularities. For this purpose, Chart 18 plots the annual growth rates of real loans to households (deflated by the GDP deflator), together with their average over the last two decades. For illustrative purposes, the figure also depicts the annual growth rates of euro area real GDP.

Over the last twenty years, the annual growth rate of loans to the private sector has followed a series of relatively long cycles, in turn positively correlated with the general business cycle. When real GDP growth falls below its historical average, real loan growth (with some exceptions, such as the mid-1990s) usually does so too. Looking in more detail at the last few years, the annual growth rate of real loans to households rose significantly after the start of Stage Three of EMU, reaching a historical peak of over $10 \%$ in mid-1999. Thereafter, it declined sharply in real terms throughout 2000 and 2001. After bottoming out at end-2001, it has since followed an upward trend, returning to above its long-term average in the course of 2004 and so far in 2005. There is no indication that, during the period of subdued economic growth in the past few years, real lending growth has fallen to exceptionally low rates, at least when compared with the rates reached in the previous period of economic weakness at the beginning of the 1980s and 1990s.

Borio and Lowe (2002) suggest that "credit gap" measures may provide a more relevant indication of the magnitude of loan developments than their annual growth rates. They define their preferred measure as the deviation of the credit aggregate to GDP ratio (the "credit ratio") from its long-term trend as estimated by the Hodrick-Prescott filter (see Borio and Lowe, 2002). Chart 19 presents the results of applying Borio and Lowe's methodology to the ratio of loans to households over GDP in the euro area. The chart shows the emergence of a sizeable positive gap in the run-up to Stage Three of EMU. After peaking at the beginning of 1999, the loan gap declined gradually, although it remained in positive territory until the end of 2000. A large negative deviation of the loan ratio from its trend level then accumulated in the course of the following two years. This negative deviation, however, declined over the next few quarters (Chart 19), with the gap recording values fairly close to zero between end-2003 and the first half of 2004. A significant positive gap has since re-emerged, as a result of strong loan dynamics. As a caveat, it should be recalled that the Hodrick-Prescott filter suffers from a well-known end-point bias, as it assigns a disproportionately large weight to the last observations in the estimation of the trend. To the extent that the exceptional values of the ratio of loans to GDP observed in 1999-2000 shift the trend upwards, this may result in an underestimation of the credit gap towards the end of the sample period.

Overall, the effect of the economic slowdown from 2001 to 2004 on loans to households seems to have been slightly more significant than would have been inferred from the exercise based on growth rates. Nevertheless, the two exercises seem to lead to the conclusion that, from a longer-term perspective, the development of loans to households from 2001 to 2004 does not appear to have been 
Chart 19 Deviations of the ratio of bank

loans to households to GDP from its longterm trend

(as a percentage of the trend)

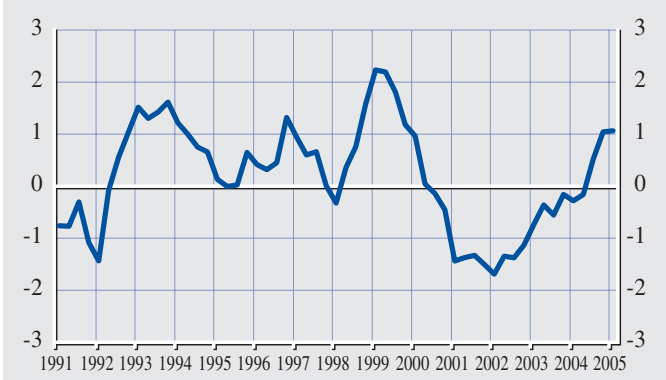

Source: ECB calculations.

Note: The underlying trend has been obtained by means of the Hodrick-Prescott filter (setting the lambda parameter to 1600). The initial sample includes the first ten years of the sample (Q1 1981-Q4 1990) and is extended recursively by adding one quarterly observation at a time.

excessively weak, and has gained significant momentum more recently.

A closer look at the development of loans to households according to their purpose shows

\section{Chart 20 Bank loans to households} according to their purpose

$$
\begin{aligned}
& \text { (annual growth rates) } \\
& \ldots \text { total loans to households } \\
& \ldots-\text { lending for house purchase } \\
& \ldots \text { - consumer credit }
\end{aligned}
$$

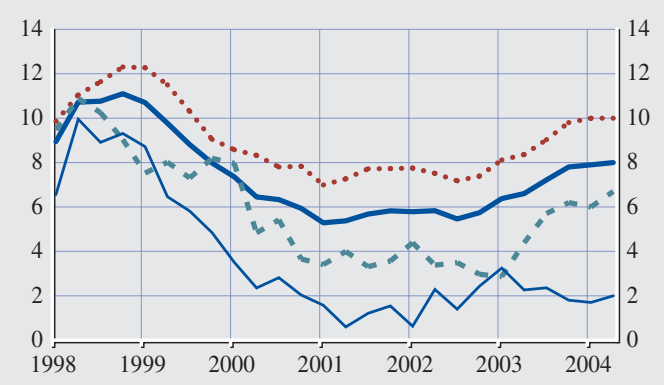

Source: ECB.

Note: Total loans to households are adjusted for seasonal and calendar effects.

that a major factor supporting the dynamics of loans to households over the past few years has been the relatively rapid growth in loans for house purchase (see Chart 20). In terms of loan categories, housing loans have consistently

Chart 2 I Changes in credit standards applied to the approval of loans to households for house purchase

(net percentages)

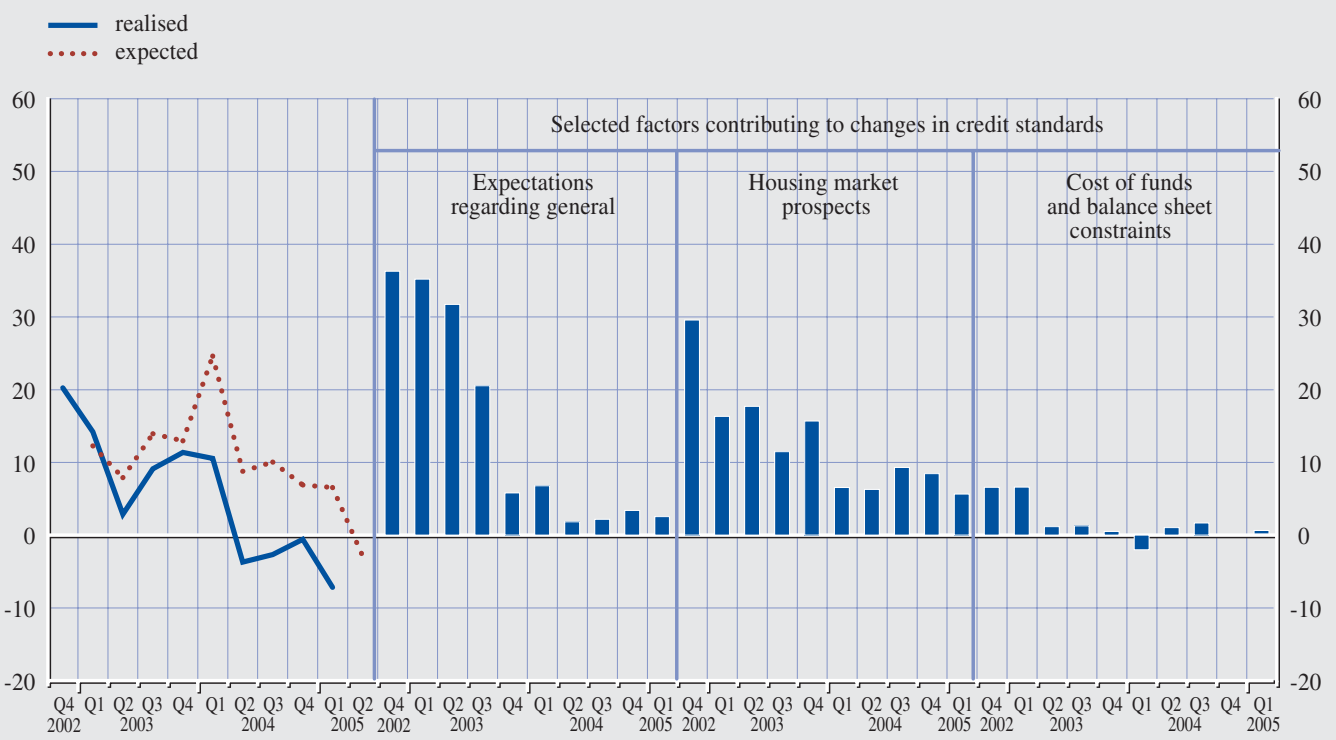

Source: ECB

Note: Net percentages are defined as the difference between the sum of "contributed considerably to tightening" and "contributed somewhat to tightening" and the sum of "contributed somewhat to easing" and "contributed considerably to easing". 
grown more than the other two types of loans to households since the start of Stage Three of EMU. The relatively strong growth in housing loans observed from 2003 to early 2005 mainly reflected the combination of favourable euro area-wide financing costs with sustained house price inflation in some euro area countries. ${ }^{24}$ In addition, it is possible that, during the period of considerable financial, economic and geopolitical uncertainty between 2001 and 2003, households may have come to see houses as a relatively safe category of investment assets (Montoya and Trimbath, 2002). By contrast, annual growth in both consumer credit and other lending to households, such as loans to small unincorporated companies included within the household sector and loans to finance academic studies, was significantly lower.

In terms of overall credit conditions on housing loans to households, the Bank Lending Survey provides information on the different factors contributing to movements in credit standards. In this regard, Chart 21 indicates that there has been a loosening in the credit conditions applied when approving loans for house purchase in recent quarters. The main factors contributing to this development have been better expectations regarding general economic activity (as reflected by the downward trend for this factor), as well as less concern on the part of financial institutions regarding future developments in housing market prices (see Box 5 below for an explanation of country developments).

24 Ayuso and Restoy (2003) argue that the high levels of house price inflation observed in the late 1990s reflect, to some extent, a process of disequilibrium adjustment, following previous declines in prices below equilibrium levels.

\section{Box 5}

\section{COUNTRY DEVELOPMENTS IN BANK LOANS TO HOUSEHOLDS}

Developments in loans for euro area households display a significant degree of heterogeneity across countries, which, to some extent reflects differences in aggregate demand developments. Two factors that may have played a major role in creating inter-country heterogeneity in demand conditions are first, the varying impact of the switch to a low, stable inflation regime on the level and volatility of national mortgage rates, and second, differences in house price developments. With regard to the first factor, lower interest rates increase the affordability of housing for broader segments of the population and lead to higher demand for housing loans. Chart A shows that the countries with the strongest average loan growth in recent years are also those that have experienced the largest declines in long-term interest rates over the same period.

As regards the second factor, i.e. intercountry differences in house price dynamics, there is evidence of a positive correlation

\section{Chart A Euro area bank housing loans and interest rates}

(average annual rate of growth between Q3 1998 - Q1 2005, $\mathrm{X}$-axis; change in long-term interest rates over the same period, in percge, $y$-axis)

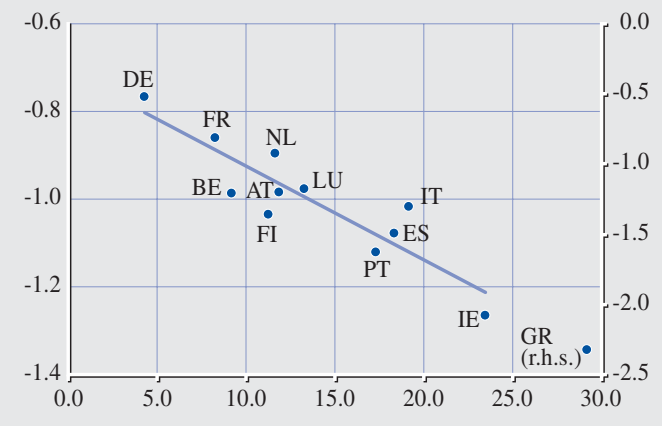

Source: ECB calculations.

Note: In the case of Greece, the decline in interest rates refers to the period Q1 1999-Q1 2005. The observation for Greece is excluded from the interpolation. 
between the development of house prices and housing loans across the euro area countries over recent years. This correlation is well illustrated by Chart B, which plots the average annual rate of inflation in residential property prices over the period 1998-2004 against the average annual growth rate in housing loans to banks over the same period. It shows that the countries with higher house price increases in recent years have also usually been those with stronger loan growth.

Beyond demand factors, diverging developments in mortgage lending activity across countries may also depend on the housing supply side and on the persistence of inter-country differences in the institutional framework of the banking and housing sectors (see for instance Borio, 1997; Maclennan, Muellbauer and Stephens, 1998; and ECB, 2003b).

\section{Chart B Bank housing loans and house prices}

(average annual rate of growth as a percentage over the period 1998-2004)

y-axis: House prices

$\mathrm{x}$-axis: Loans for house purchase

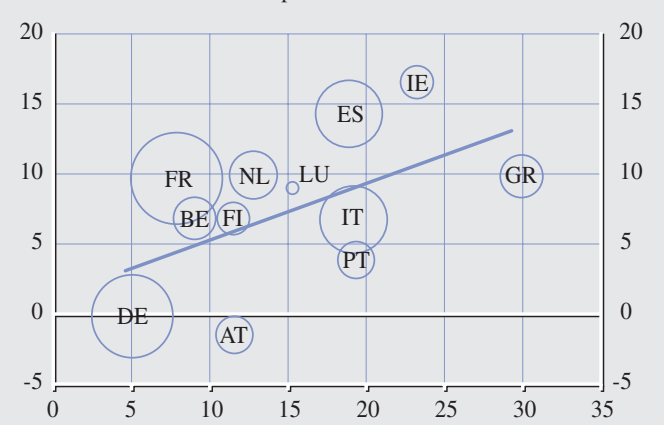

Source: ECB and ECB calculations.

Note: Owing to data constraints, for Luxembourg, the sample pote: Owing to data constraints, for Luxembourg, the sample period is 1998-2002, for Greece, 1999-2004. Countries have
been scaled according to their weight in euro area GDP (based been scaled according to their weight in euro area GDP (b
on 2003 purchasing power parity (PPP) exchange rates.

\subsection{BALANCE SHEET POSITION OF HOUSEHOLDS}

Similar to non-financial corporations, the balance sheet position of households (i.e. their net wealth and its composition) is an essential factor behind the demand for loans and the level of interest rates applied to loans to households. Households' balance sheets have a number of particularities of their own which are relevant for the assessment of their financing conditions. First, households' wealth is composed of housing. Second, households traditionally have an aggregate net lending position. Third, a non-negligible share of households' actual wealth - such as their human capital or their implicit claims on public pensions - is generally not accounted for in standard statistics, but does affect households' ability to assume and repay debt.

In the ECB's regular assessment of euro area households' financing conditions, the main macro-financial indicators regularly monitored are the net lending position, leverage ratios and the debt service burden. In addition, attention is paid to the development of housing wealth, ${ }^{25}$ and efforts are currently under way to develop the data, and related analysis, on the household sector according to households' sub-categories (such as income).

The net lending position of households equals the difference between the gross saving of households and their capital formation (i.e. essentially their house purchase). On an aggregate basis, this balance is largely positive in the euro area (see Chart 22).

The debt to disposable income ratio is a commonly used measure of debt sustainability, as the debt will be virtually repaid out of future flows of income, and over-indebtedness might need to be corrected in the future through a moderation in consumption. To complement the debt to income ratio, the ratio of debt to financial assets also takes into account the value of the collateral in the form of securities that households might use as a guarantee for

25 Homogeneous data on housing wealth in the euro area are currently unavailable, although there are some national data on house price developments and/or housing wealth. 


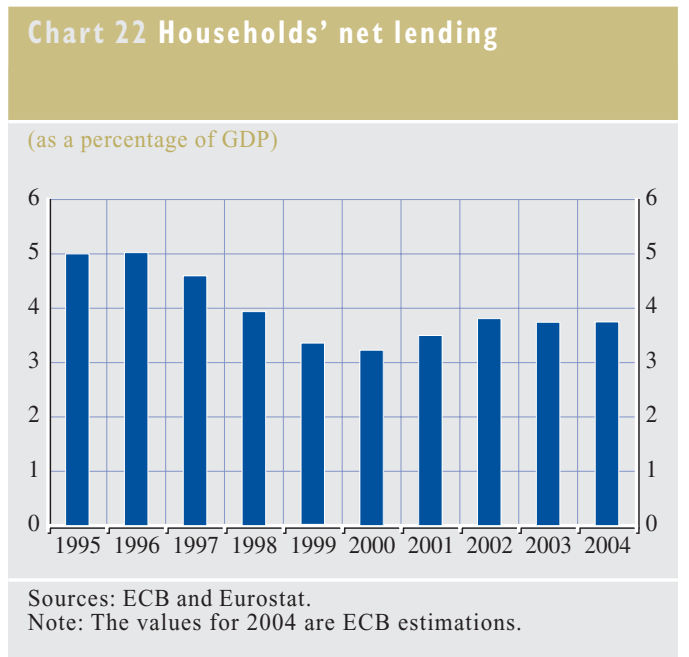

their loans. This indicator has become more useful as euro area households have substantially increased their total financial asset holdings in recent years (by $46 \%$ from 1995 to 2003 ).

As the bulk of households' assets is composed of housing wealth, the ratio of debt to housing wealth is a useful complementary indicator of households' solvency. In the absence of comprehensive and homogeneous data on the housing stock in the euro area, a proxy for the development of this indicator can be defined as the series of the stock of mortgage debt deflated by an indicator of house price level in the euro area.

Among debt service burden indicators, ratios of gross interest payments, interest payments and repayment of the principal, and net interest receipts (interest receipts minus interest payments) are monitored by the ECB. Such monitoring involves the assessment of the sensitivity of the household debt service burden to changes in policy and market interest rates. Such sensitivity is currently assessed using estimates of the proportion of mortgage loans with floating rates and of the average duration of loans to households.

As was the case in the analysis of non-financial corporations, aggregate macro indicators may

\section{Chart 23 International comparison of household debt in 2004}

conceal potentially diverging developments at the microeconomic level. In fact, the use of microanalysis by categorising households according to income or net worth is particularly necessary because of the very wide dispersion in households' income, and, even wider dispersion in households' wealth. This disaggregated analysis would be particularly necessary in assessing the impact of a downturn in house prices on households' net worth, gross saving and spending behaviour.

\section{Developments of the balance sheet position of households}

In recent years, the aggregate net lending position of the household sector has remained positive (see Chart 22). At the same time, the aggregate indebtedness of euro area households has increased significantly, reaching historically high levels (see Chart 24). Despite the rise in household debt, the ratio of gross interest payments to disposable income has remained contained in a low interest rate environment (see Chart 25). Household debt, however, remains relatively low in the euro area by international comparison (see Chart 23). On the asset side, the significant increase in housing prices has helped to raise households' overall wealth, ${ }^{26}$ so that the growth

26 In the euro area as a whole, the average annual rate of growth in house prices was around 7\% from 2000 to 2004 . 
Chart 24 Euro area households' debt ratios

(percentages)

.... debt to disposable income (left-hand scale)

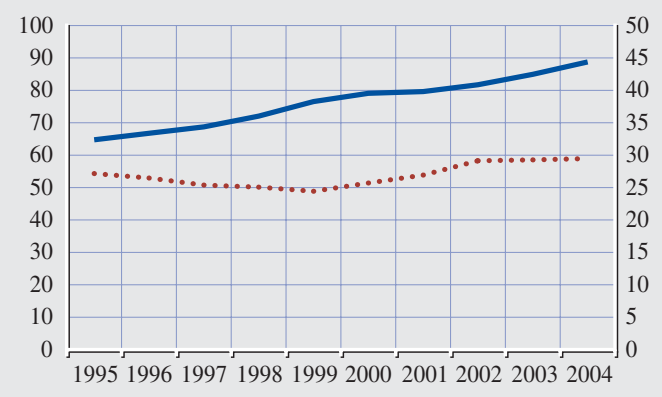

Sources: ECB and Eurostat.

Note: The values for 2004 are ECB estimations. in household debt may be put into perspective when deflated by house prices (see Chart 26).

Admittedly, the higher level of household indebtedness creates some financial risks. The sensitivity of households' disposable income to interest rate changes has increased. Such sensitivity depends, beyond the debt level itself, on the proportion of loans with adjustable rates, which has been estimated at around one-third of the total amount of loans outstanding ${ }^{27}$, and which has tended to increase

\section{Chart 26 Households' mortgage debt in real terms in the euro area}

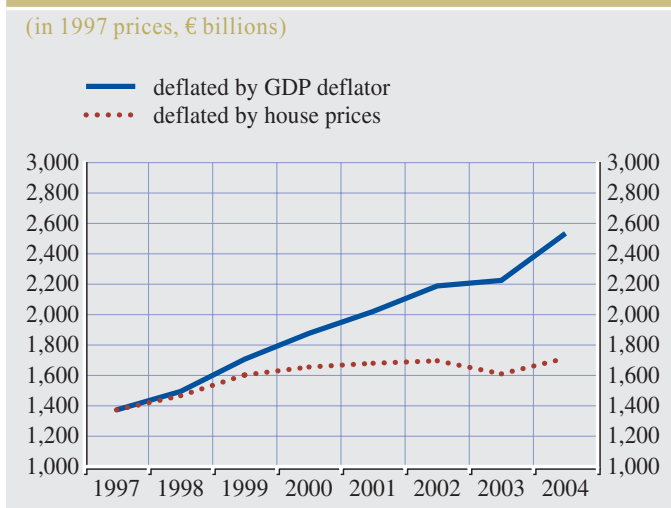

Sources: ECB and Eurostat.

Note: Euro area house prices are estimations based on national data.

\section{Chart 25 Debt service burden of households}

(as a percentage of disposable income)

$$
\begin{array}{ll}
\text {.... gross interest payments } \\
=- \text { - } \\
\text { nepayment flows }
\end{array}
$$

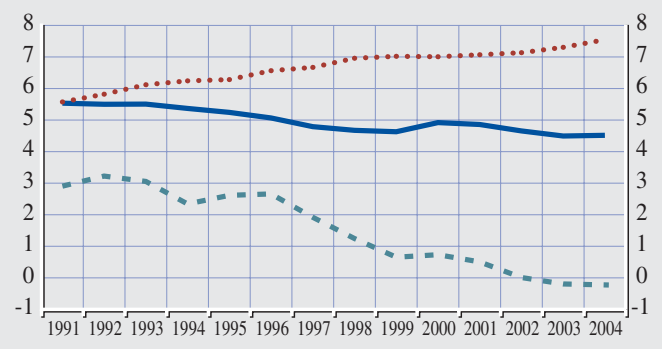

Sources: ECB and Eurostat.

Note: The values for 2004, and for repayment flows (all years), are ECB estimations.

in recent years. Similarly, the decline in the interest payment burden of households has been accompanied by a rise in households' repayment obligations (see Chart 25). ${ }^{28}$ The impact of a possible downturn in house prices on households' financial positions should also be considered (see ECB, 2003, and Debelle, 2004), even though such risks should be mitigated at the euro area level, since a large part of the housing stock is for own occupation. Furthermore, mortgage-backed financing (such as mortgage equity withdrawals) seems to be a relatively limited practice in the euro area as a whole, as compared with the United States or the United Kingdom for instance, thus attenuating the impact of a housing price correction on consumption through that channel.

27 Tentative estimations based on national sources using data from the European Mortgage Federation. See also ECB (2003a and 2004c).

28 This estimation of repayment flows is based on the structure of the MFI balance sheet according to maturity bands. The upper band of loans for house purchase is assumed to be fixed according to information from the European Mortgage Federation, while in some countries (for instance, France and Finland) there is evidence of an extension to the duration of loans, which, all things being equal, tends to reduce the monthly instalments for each euro borrowed. 


\section{I INTRODUCTION}

Owing to its position at the centre of the financial system, the banking sector plays a pivotal role in the transmission of monetary policy impulses. In this regard, traditional macroeconomics tended to overlook the role of banks and how they interact with the real economy, but now there is a substantial body of empirical and theoretical evidence which suggests that changes in the position of the financial sector - as a key part of the transmission mechanism of monetary policy can strongly influence the real economy (see Greenwald and Stiglitz, 2003, and Chapter 2).

Consequently, this chapter provides an overview of some indicators of the conditions of the banking sector in terms of the effect they can have on the transmission of monetary policy. It starts by considering how monetary impulses are actually transmitted to borrowers by discussing developments in banks' lending margins, as well as the Eurosystem Bank Lending Survey, which is a particularly useful indicator of financing conditions of banks and corporations (see Section 5.2). In addition, Box 6 provides empirical evidence on the speed of pass-through from market to lending rates in the euro area as observed during Stage Two and Stage Three of EMU, and reviews the issues at stake in examining the bank lending rate passthrough process. Among the many factors ultimately influencing the adjustment of retail bank interest rates to marginal pricing costs, one of the main lessons to be drawn from banking structure studies is that the pricing behaviour of banks may depend on the degree of competition and contestability in the different segments of the retail bank market.

This chapter does not aim to be exhaustive and only examines selected indicators of banks' conditions available until late 2004. The indicators are divided into those derived from banks' accounting information (see Section
5.3) and those derived from financial market data (see Section 5.4).

Overall, these indicators suggest that banks' profits and capital levels had been dented in 2001 and 2002. It cannot be ruled out that this could have had some impact on banks' lending standards with the result that some corporate borrowers might have had more difficulty raising external finance from banks during this period. On the other hand, banks' capital levels remained relatively high in the euro area as a whole, and loan-loss provisions were contained, standing well below the levels reached in the early 1990s. In addition, indicators calculated from banks' accounting and market data, as well as the Bank Lending Survey suggest that the state of the banking sector improved progressively. While it cannot be excluded that credit supply effects might have played a role in certain countries for certain institutions, these effects are unlikely to have had a significant effect on the overall transmission of monetary policy in the euro area. Information from bank lending spreads suggests that most spreads increased in 2003 and 2004, reflecting the rise in the leverage of households and corporations, with the exception of spreads on mortgage loans, probably due to the increases in housing prices in most euro area countries as well as stronger banking competition in this sector.

\subsection{DEVELOPMENTS IN BANK LENDING SPREADS}

The development of bank lending spreads with respect to benchmark government bond yields provides an indication of the actual transmission of market rates to borrowers via the banking sector.

One of the main determinants of changes in bank lending spreads is banks' perception of borrowers' credit risk, which is embodied in the credit risk premium. Borrowers' credit risk is mainly linked to the level and volatility of their income, as well as to their outstanding 
debt. Consequently, the level of credit risk fluctuates over the economic cycle, typically increasing during recessions and declining during economic expansions. There are also a number of other generic factors that could also influence lending spreads, in particular the state of the banking sector. For instance, a more competitive banking system would ensure a swifter transmission of monetary policy impulses to borrowers, which implies, other things being equal, narrower lending spreads. Likewise, a sound and profitable banking sector would also contribute to a smoother transmission of monetary policy (see Chapter 2).

Institutional and legal factors could also play a role. In a number of regions, there is a strong emphasis on the relationship between lenders and borrowers over the economic cycle in the form of relationship banking. This contributes towards lower lending margins, as well as easier access to credit for previous borrowers. Finally, the evolution of collateral prices could also be a major factor determining lending spreads, particularly in the case of mortgage lending to households. Hence, spreads on

\section{Chart 27 Spreads of bank lending interest rates to households and comparable market} rates

(as a percentage)

rate on consumer lending minus twelve-month money market rate

.... rate on loans to households for house purchase minus two-year government bond yield

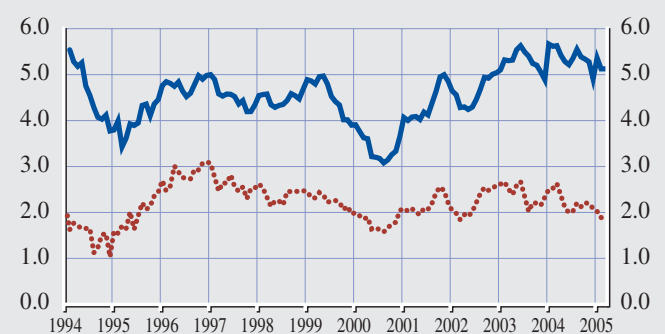

\section{Source: ECB.}

Notes: MFI interest rates have been aggregated using amounts outstanding whenever available. Otherwise, aggregated new business volumes for 2003 have been used. In January 2003 there was a statistical break in the interest rate series. To take this into account, past levels of previous interest rate statistics data were adjusted on the basis of the difference between the old and the new interest rate statistics levels in January 2003. mortgage interest rates will depend on the fluctuations of housing prices, as borrowers are usually able to pledge their purchased residence as collateral. ${ }^{29}$

\section{Developments in bank lending spreads}

Despite the increase in household debt (see Chapter 4), spreads between bank interest rates on loans for house purchase and comparable market rates have not increased substantially since the late 1990s (see Chart 27). In fact, spreads on loans for house purchase have declined since 2001 , bolstered by increases in house prices in most euro area countries. By contrast, the spreads on loans for consumer credit increased during the same period, probably reflecting the step-up in consumer leverage and a degree of credit tightening.

29 That is, the borrower could pledge a property that the lender is entitled to repossess should the borrower be unable to repay the loan. Other developments, such as financial regulation or the degree of financial innovation, will also have a bearing on the cost of financing. For instance, the development of securitisation in the United States has allowed US banks to price their mortgage lending more competitively by passing through large amounts of their mortgage loans to the market, thereby reducing their level of on-balance-sheet risk exposure.

\section{Chart 28 Spreads of bank lending interest \\ rates to non-financial corporations and} comparable rates

\section{(as a percentage)}

_rate on loans of up to one year minus six-month money market rate

.... rate on loans of over one year minus two-year government bond yield

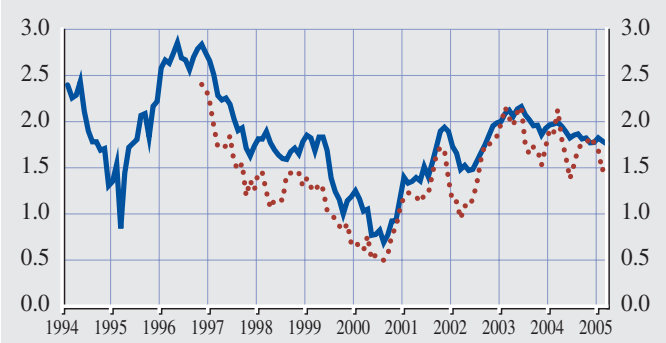

Source: ECB

Notes: MFI interest rates have been aggregated using amounts outstanding whenever available. Otherwise, aggregated new business volumes for 2003 have been used. In January 2003 there was a statistical break in the interest rate series. To take this into account, past levels of previous interest rate statistics data were adjusted on the basis of the difference between the old and the new interest rate statistics levels in January 2003 
In terms of lending to corporations, the spreads on bank interest rates on loans to non-financial corporations and comparable market rates increased steadily - both for short and longterm loans - from 2001 to late 2004. This increase has taken place after market agents re-evaluated their profit expectations following the large declines in stock market prices in 2001, thereby probably increasing the financial risk of borrowers linked to the buildup in corporate debt (see Chart 28). The increase in lending rates for non-financial corporations also seems to have coincided with a worsening in the conditions of the banking sector during those years (see the next section). By contrast, in late 2004 and early 2005 corporate lending spreads declined, probably owing to the improvement in profits in the corporate sector.

\subsection{BALANCE SHEET POSITION OF BANKS}

As indicated earlier, the state of the banking sector is likely to play a major role in banks' price-setting strategies. Indicators of the current and historical state of banks are often constructed by aggregating indicators of individual financial institutions that are based on publicly available balance sheet accounting information. $^{30}$ The use of individual bank accounting data seems warranted from a macroeconomic perspective. For instance, Peek and Rosengren (2003) find that confidential bank supervisory information can be used to improve forecasts of major macroeconomic variables, and that information on banks' conditions could improve the effectiveness of monetary policy. In this regard, one commonly used method for analysing banks is to focus on key areas, such as capital adequacy, asset quality, earnings, liquidity and management quality. Before considering the developments of selected indicators for euro area banks, the capital adequacy ratios and asset quality of banks are briefly analysed.

The capital position is one of the key elements in the assessment of the specific state of banks.
The reason for this is the function of bank capital, which acts as a buffer to cover unexpected losses with a sufficient margin to inspire confidence among depositors, investors and regulators. All other things being equal, substantial declines in a bank's capital ratio could signal a deterioration in its ability to withstand adverse shocks. In such a situation, if a bank's capital falls below a certain regulatory or private threshold, this could affect its ability to grant credit. One of the indicators most often used to measure a bank's capital is the total capital to assets ratio. Furthermore, to obtain an idea of the "quality" of the capital ratio (where quality describes the ability of the different components of bank capital to withstand shocks), a number of related indicators could also be developed, such as the evolution of the different components of bank capital. Consequently, total capital is generally split between core capital (tier 1) and supplementary capital (tier 2) capital. In addition, the ratio of bank capital to riskadjusted assets could be considered. In economic terms, the main element shared by all capital items is that they are not due in the short run, and that they are subordinated to deposits and other traditional bank liabilities. Moreover, the main economic reason behind the distinction between tier 1 capital and tier 2 capital is that tier 1 capital is more permanent and externally more accountable. It could also be argued that the use of the market value of capital is much closer to the economic definition of bank capital than the use of accounting capital, as it normally gives a more accurate signal of the net worth and true solvency position of banks (see Saunders, 2002, for an explanation of this point).

In terms of asset quality, one of the main indicators traditionally used to gauge the quality of banks' portfolios is that of loan-loss provisions. In general, an upward trend in loanloss provisions signals a deterioration in the quality of financial institutions' portfolios, ultimately negatively impacting the net income

30 See ECB (2004f) and ECB (2004g). These studies on the banking sector are conducted regularly. 
and solvency of these institutions. However, while this indicator could be useful in assessing the quality of credit portfolios, it is often argued that provisions vary significantly across countries, and that in many countries they tend to peak well after the economic cycle has bottomed out (Laeven and Majnoni, 2002).

\section{Developments in the balance sheet positions of banks}

Chart 29 shows the evolution of core capital in the euro area. It suggests that from 1996 to 2004 the ratio of median core capital to total assets for the largest 50 banks remained broadly unchanged within the $7-8 \%$ range during that period. In particular, core capital ratios remained robust throughout the latest economic slowdown. ${ }^{31}$ A particularly positive sign was the increase in the average capital ratio of the weakest $10 \%$ of capitalised banks. The improvement in the capital ratios of the weakest banks was particularly interesting from a monetary policy perspective, as these institutions are more likely to restrict credit supply in periods of slow economic growth.

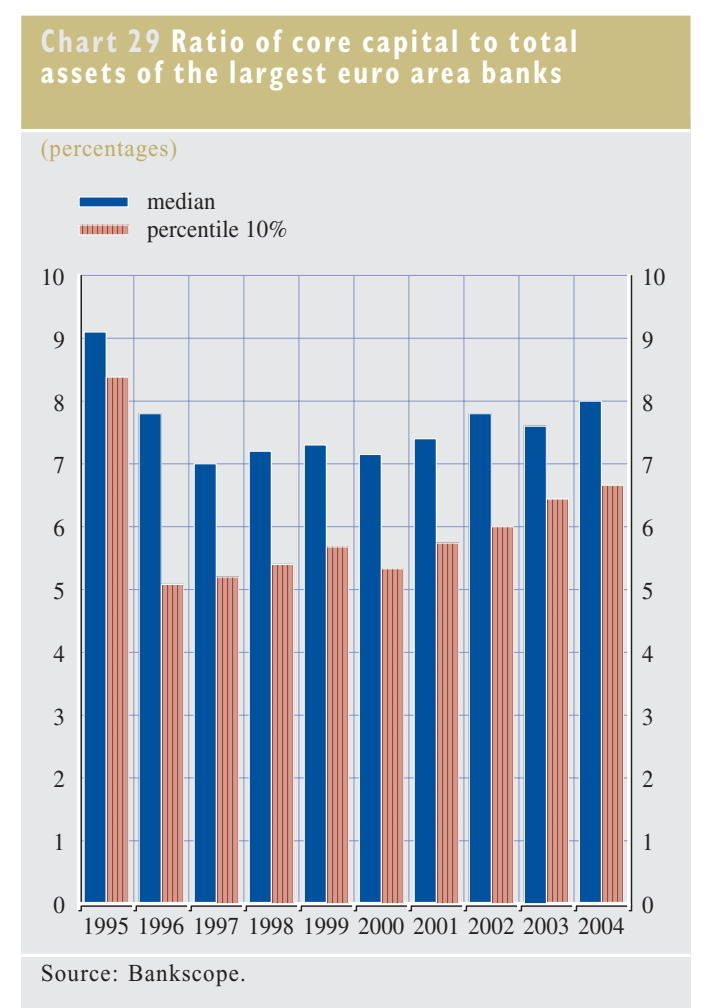

For the largest listed banks, balance sheet information is also available more regularly at quarterly intervals. For these institutions, Chart 30 shows an additional measure of banks' capital positions which is the market to book value ratio. ${ }^{32}$ In the euro area, this ratio declined considerably for the largest banks from the beginning of 2000 up to the beginning of 2003, largely influenced by the overall decline in stock market prices. From the beginning of 2003 to early 2005, however, the capital position of the largest banks, as perceived by the market, improved considerably, probably reflecting the better outlook in banks' earnings and the relatively low level of loan-loss provisions, despite the slowdown in economic activity in 2002 and 2003.

Loan-loss provisions as a proportion of net interest income increased somewhat in 2001 and 2002, particularly for the $10 \%$ of banks with the highest level of loan-loss provisions (see Chart 31). While this increase reflected the slowdown in economic activity, the level of loan-loss provisions remained well below that experienced in the early 1990s (ECB, 2004d). In 2003 and 2004 the asset quality of the largest banks improved, as reflected by the decline in the ratio of loan-loss provisions to total assets.

In terms of profitability, banks' profits measured as the return on total assets declined substantially from their peak in 2000 (see Chart 32). Although retail lending to consumers and deposit growth remained strong in 2002 and 2003, the paucity of investment banking deals and lower commissions derived from reduced asset management activity partly

31 The simple ratio of core capital to total assets has been found to be a good predictor of bank failure. See Estrella, Park and Peristiani (2000).

32 The market to book ratio is defined as the stock market price of a bank share multiplied by the number of shares outstanding and divided by the accounting value of total capital. However, the use of market value is not without caveats. For example, it has often been argued that it might induce excessive volatility, particularly in the case of the banking industry, where banks' credit portfolios remain more or less illiquid. 
Chart 30 Market to book value of the largest listed euro area banks

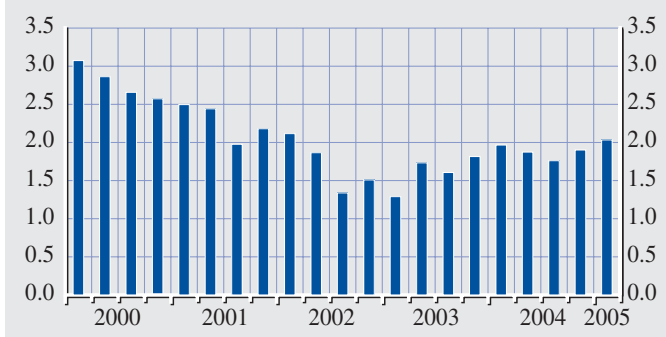

Source: Bloomberg.

Note: Only the largest listed banks that provide quarterly data are included.

dented banks' revenues during this period. A comparison with the United States (see Chart 33) suggests that the largest American banks continued to be, on average, more profitable than their European counterparts. This is partly due to the stronger emphasis on relationship banking in the euro area banking system. In addition, American banks had already seen a noticeable improvement in profits since 2001, whereas euro area banks' profits improved substantially in 2004 .

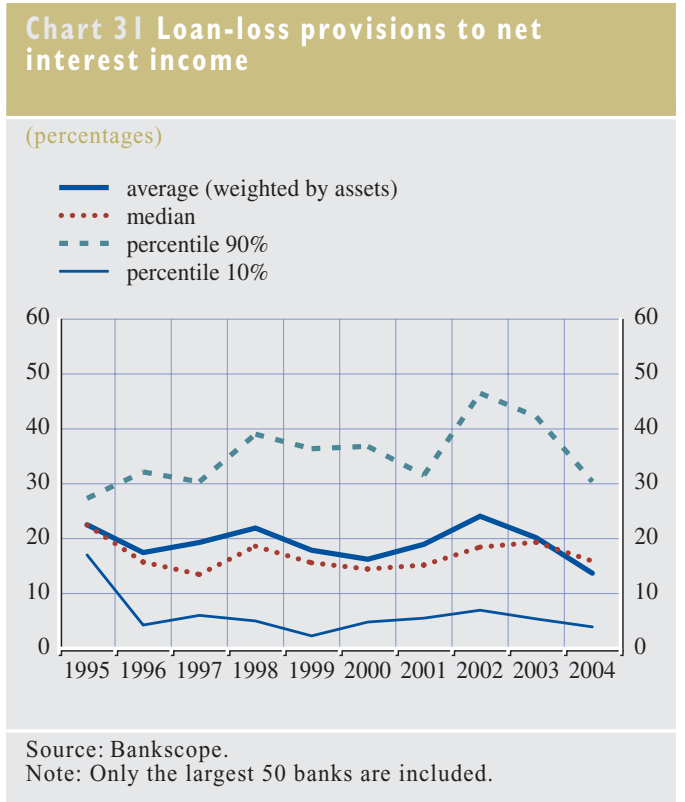

Chart 32 Return on assets of the largest euro area banks

(percentages)

average (weighted by assets)
percentile $10 \%$

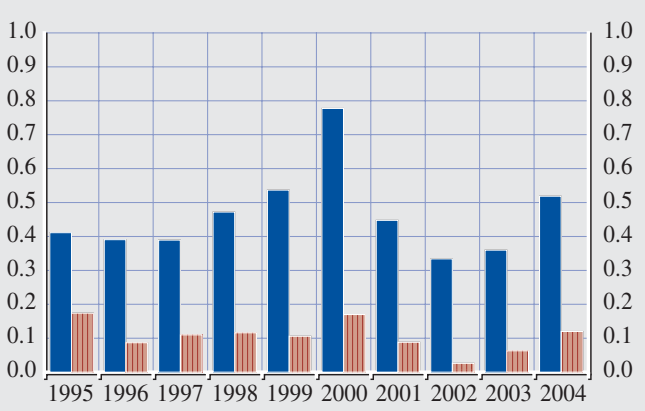

Source: Bankscope.

Note: Only the largest 50 banks are included.

Hence, despite the slowdown in economic activity, the resilience of the banking sector from 1996 to 2004 contributed to the continuing smoothness in the transmission of monetary policy. Box 6 shows how bank lending rates adjust to market interest rate developments in the lending rates adjust to market interest rate developments in the euro area. Some of the reasons for the resilience of the financial system are structural in nature, such as the use of better risk management techniques, diversification of the sources of

\section{Chart 33 Return on assets of the largest euro area and US banks}

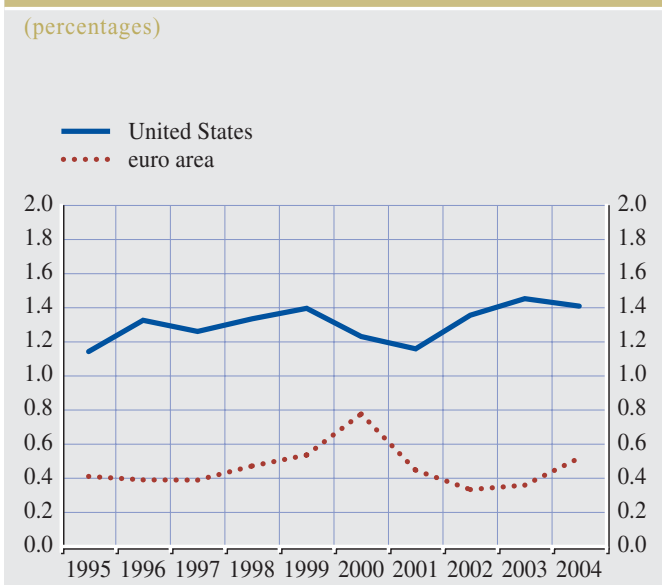

Source: Bankscope.

Note: Only the largest 50 banks in the United States and the euro area are included. 
income by banks, as well as better opportunities for the largest banks to offload part of their risks via credit derivatives. Nevertheless, the soundness of banks during that period was probably also supported by some less permanent reasons, three of which can be identified as the main ones. First, from May 2000 to June 2004, many euro area banks benefited from a significant revenue windfall from the reduction in short-term interest rates. ${ }^{33}$ Second, mirroring the lacklustre performance of the stock market during this period, risk aversion forced investors to look for safer investment options, such as deposits. As retail deposits are usually a major source of cheap funding for banks, the increase in deposits provided banks with access to lower-cost funds from customers. Third, the relative resilience of consumption and house prices in most euro area countries also had a positive effect on banks (see ECB, 2004e and ECB, 2004h).

The Bank Lending Survey can also shed some light on how the banking sector could directly affect financing conditions. For instance, it shows how developments in the capital positions of banks could influence the actual credit conditions imposed by banks upon retail and corporate borrowers. It can also provide information on how lenders perceive competition from other banks and from nonbanks' sources of corporate financing, such as the corporate bond market.

In this regard, between late 2003 and late 2004, the impact of bank capital on credit standards declined significantly in the euro area, while the competition component weighted towards an easing of credit conditions (see Chart 34).

33 This benefit, assuming that the interest rate risk has not been fully hedged, comes from the maturity transformation role of banks. Given that the maturity of bank loans is, on average, longer than that of deposits, the decline in short-term interest rates (i.e. a steepening of the yield curve) has generally allowed banks to benefit from substantial revenues from outstanding loans.

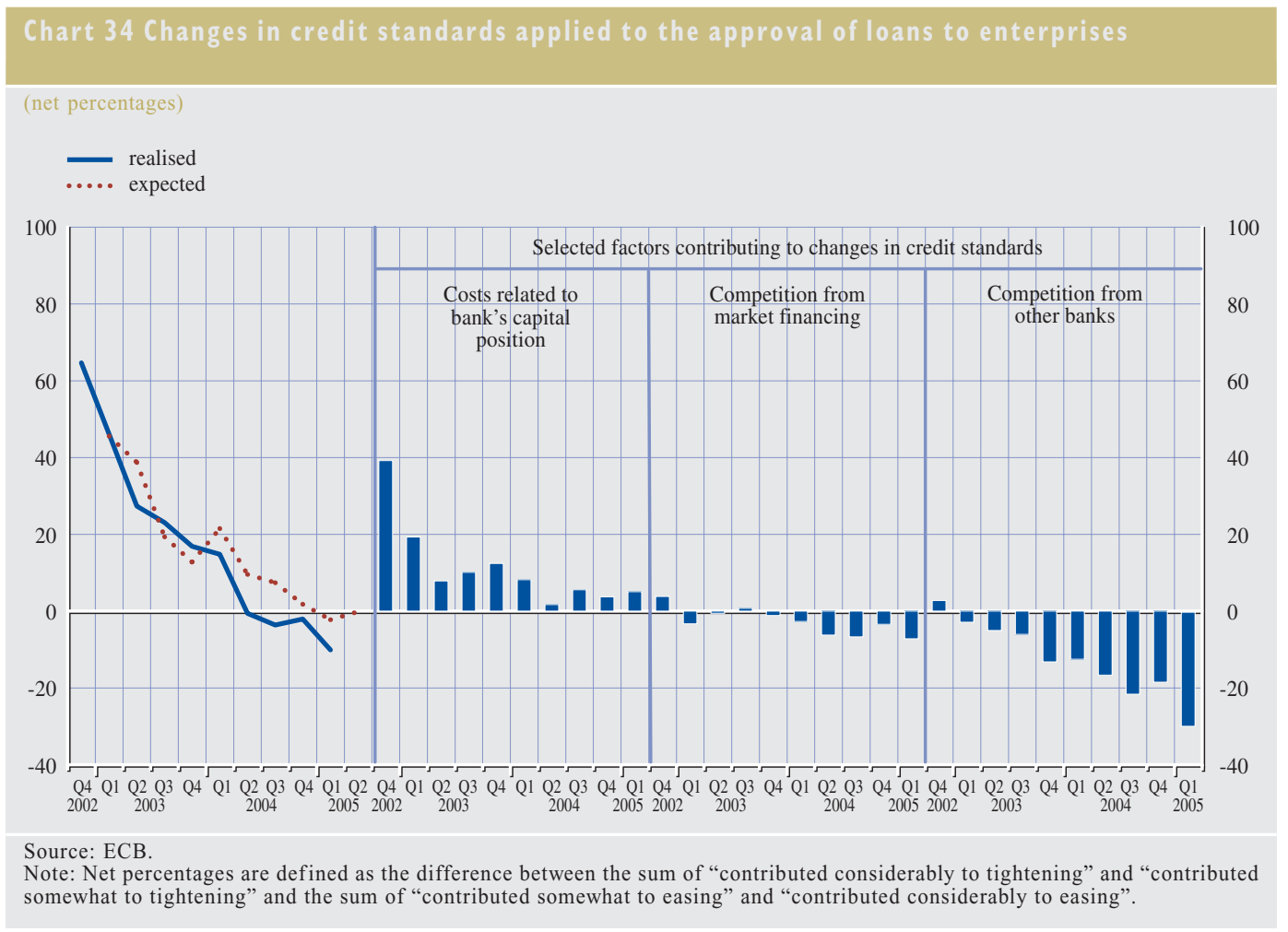


Box 6

\section{HOW DO BANK LENDING RATES TYPICALLY ADJUST TO MARKET INTEREST RATE DEVELOPMENTS?}

The adjustment of bank lending to market interest rate developments is a key link in the monetary transmission process (see Chapter 2). This box reviews the relevant issues at stake in examining the bank lending rate pass-through process and presents the typical adjustment of bank lending rates to market interest rate developments in the euro area since Stage Two of EMU.

\section{Key issues}

Four main issues emerge when examining the interest rate pass-through (de Bondt, 2003).

First, a distinction should be made between an immediate or short-term adjustment of bank lending rates to changes in official and market interest rates and a final or long-term adjustment. There is usually a delay in the adjustment of bank interest rates to market interest rate developments. The immediate pass-through tends to be incomplete, although, in the long term, there is usually a close to one-to-one pass-through of changes in market interest rates to retail bank interest rates. Short-term stickiness of retail bank interest rates can be explained by, among other factors, administrative costs of price changes, maintaining bank-customer relationships, risk premia and uncertainty about whether market interest rate changes are temporary or permanent.

The second important issue for the retail bank interest rate pass-through process is that maturity matters. For instance, banks prefer to fund their loans with a comparable maturity to reduce the interest rate risk associated with any mismatch between the maturities of their assets and liabilities and to offer loans at rates that are competitive with those on loans granted by other financial intermediaries and on capital market sources of finances. Long-term lending rates are thus expected to adjust more to changes in government bond yields than to money market interest rate movements.

Third, the degree and speed of the interest rate pass-through might differ across different segments of the retail bank market. This reflects, among other factors, differences in the degree of competition and market power of banks, as well as in underlying credit risk profiles and collateral practices.

The fourth and final issue is that the bank interest rate pass-through may change over time. The bank lending rate pass-through depends on time-varying borrower and bank-specific characteristics, such as bank profitability and its interplay with bank refinancing conditions.

\section{Adjustment process}

The bank lending interest rate pass-through process is further examined using an empirical framework that takes into account the immediate as well as the final adjustment of bank lending rates to market interest rates with a comparable maturity, and the speed at which the final passthrough is reached. The table summarises these three key dimensions of the pass-through 


\begin{tabular}{|c|c|c|c|c|}
\hline Bank lending rate & $\begin{array}{l}\text { Comparable } \\
\text { market rate }\end{array}$ & $\begin{array}{l}\text { Immediate } \\
\text { adjustment }^{1)}\end{array}$ & Final adjustment & $\begin{array}{c}\text { Adjustment } \\
\text { speed (in months) }\end{array}$ \\
\hline \multicolumn{5}{|l|}{ RIR sample (Jan. 1994 to Dec. 2002) } \\
\hline Loans up to one year to non-financial corporations & Six months & $19 * *$ & $112 * *$ & $6.5^{* *}$ \\
\hline Loans over one year to non-financial corporations & Two years & $36^{* *}$ & $99 * *$ & $4.5^{* *}$ \\
\hline Consumer credit & Two years & $9 * *$ & $87 * *$ & $9.5^{* *}$ \\
\hline Loans for house purchase & Five years & $24 * *$ & $83 * *$ & $3.4 * *$ \\
\hline \multicolumn{5}{|l|}{ MIR sample (Jan. 2003 to Mar. 2005) } \\
\hline $\begin{array}{l}\text { Over } € 1 \text { million with a floating rate or up to one year } \\
\text { initial rate fixation }\end{array}$ & One month & $70 * *$ & $87^{* *}$ & $0.4 * *$ \\
\hline $\begin{array}{l}\text { Over } € 1 \text { million with over five years' } \\
\text { initial rate fixation }\end{array}$ & Two years & 19 & 88 & $1.9^{*}$ \\
\hline Consumer credit (annual percentage rate of charge) & Two years & 8 & 100 & $2.0 * *$ \\
\hline $\begin{array}{l}\text { Loans for house purchase } \\
\text { (annual percentage rate of charge) }\end{array}$ & Five years & 10 & $109 * *$ & $5.5^{* *}$ \\
\hline
\end{tabular}

Sources: ECB, Reuters, and estimations of a univariate error-correction model as described in de Bondt (2002a, 2005a).

Notes: 1) Adjustment in the first month. ${ }^{*}$ and $*$ denote significance at the $1 \%$ and $5 \%$ level, respectively. MIR sample based on rates on new business.

process for euro area bank lending rates since Stage Two of EMU. Two sample periods are considered. The first sample starts in January 1994 and ends in December 2002, and is based on non-harmonised national interest rate statistics (RIR). The second sample starts in January 2003 and ends in March 2005, and is based on harmonised MFI interest rate (MIR) statistics available from January 2003 onwards (ECB, 2003). The estimation results should be viewed with caution, since the interest rate cycles covered are limited, in particular for the MIR sample.

Three conclusions can be drawn from the table.

Firstly, the immediate adjustment of bank lending interest rates to market interest rates with a comparable maturity is found to be incomplete. In other words, bank lending rates in the euro area are sticky in the short term. The proportion of a given market interest rate change that is passed through within one month is generally found to be between $10 \%$ and $40 \%$. A striking, but not surprising, feature is the high immediate adjustment of the MFI interest rate on loans to non-financial corporations over $€ 1$ million with a floating rate or initial rate of fixation of up to one year. The latter illustrates the importance of distinguishing between a floating and fixed rate. The adjustment of a floating rate is expected to be almost immediately complete.

Secondly, the final adjustment of lending rates to comparable market interest rate changes is close to $100 \%$ and, in many cases, not statistically different from $100 \%$.

Thirdly, the mean adjustment lag at which market interest rates are passed through to lending rates is typically between two and six months for bank lending rates. The main exception is the slow speed of adjustment of ten months for the interest rate on consumer lending during the period 1994-2002. The other exception is, as expected, a much quicker adjustment speed for the rate on large corporate loans with a floating rate or an initial rate of fixation of up to one year.

\subsection{SELECTED EVIDENCE FROM CAPITAL MARKETS}

As financial globalisation gathers pace, the ability of market forces to ascertain non- financial corporations' conditions is becoming an increasingly relevant issue for most industries. In the case of the banking sector, the relevance of indicators derived from capital markets data is at least as important as in other 
industries. However, their information content could become blurred for two main reasons (see ECB, 2005b, and Borio et al., 2004). First, bank loans tend to be illiquid and their value is often opaque, making it difficult for outsiders to assess the financial condition of banks. Second, the unusually high degree of government regulation and supervision in the case of the banking industry alters the incentives of market forces when monitoring banks. Despite these limitations, US empirical evidence tends to conclude that investors comprehend changes in banks' conditions and readily understand their implications for equity and liability prices (see Flannery, 1998, and Flannery et al., 2004). This evidence would suggest that market prices can reflect bankspecific information.

In general, the two major advantages of indicators of a banks' financial situation based on market data when compared with balance sheet data are that they are readily available on a frequent basis, and that they tend to be forwardlooking. On the other hand, a major disadvantage is that there are many euro area banks for which these indicators are not available, either because they are not listed or because they are not rated by credit rating

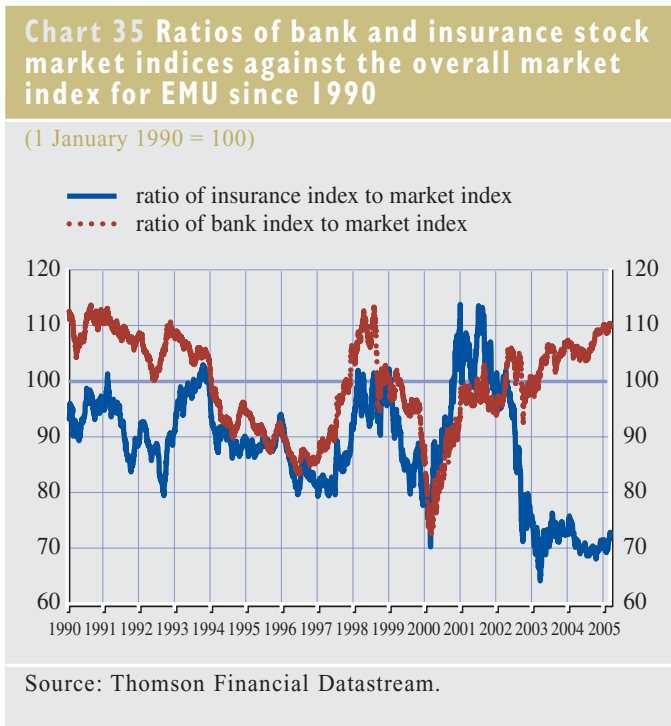

agencies. For banks with publicly traded securities, stock and bond prices provide a direct source of information about banks' conditions. In this regard, equity market variables have been found to provide relatively good predictions of the financial situation of banks both in the United States and in the euro area (Flannery, 1998, and Gropp et al., 2002 and 2005).

\section{Developments in market indicators of banks, conditions}

Information from stock market price indices in the euro area from the early 1990 s to early 2005 indicates that the banking sector index underperformed compared with the broad stock market (see Chart 35). This could be linked to market participants' particularly optimistic expectations in the second half of the 1990s for companies in the TMT sectors, which are included in the broad market index. In 2003 and 2004 the trend reversed, with the banking sector index outperforming the broad stock market index, thereby reinforcing the underlying economic value of bank capital and lowering banks' cost of tapping into the market for additional capital (see Chart 36). While stock market prices of banks are indicative of their financial situation as perceived by the market, there is one main caveat: they do not

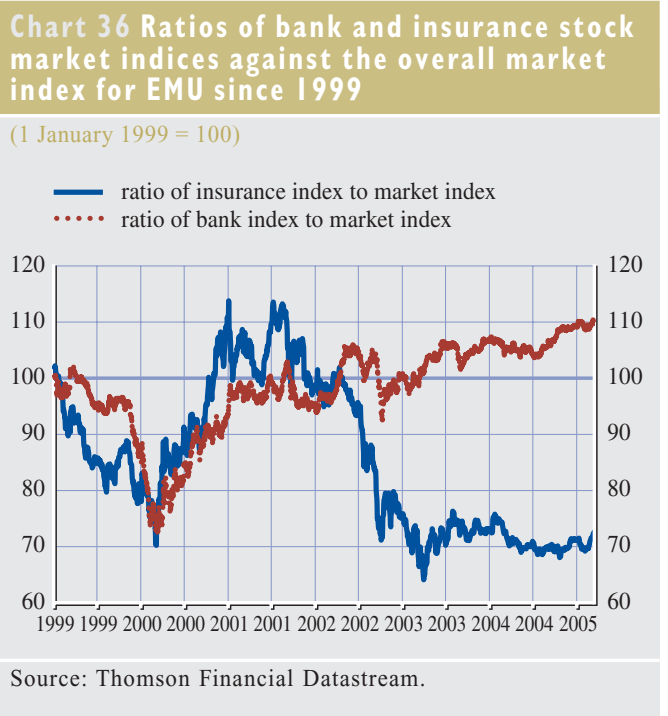




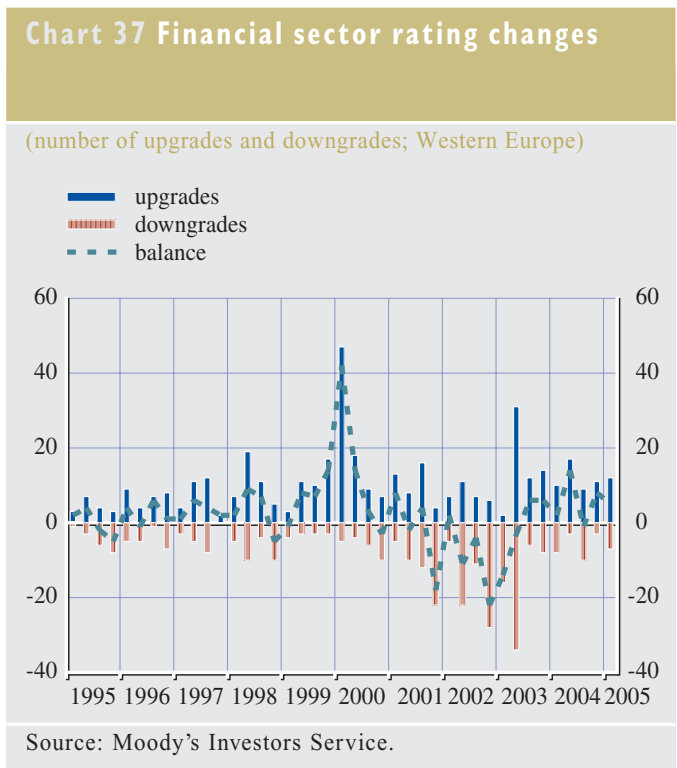

take into account the fact that equity holders might have an incentive to take on more risk rather than less when the capital level of a bank is below a certain threshold. ${ }^{34}$

Another forward-looking market indicator on banks' conditions from financial markets is the information obtained from credit rating agencies (Borio et al., 2004, and Gropp and Richards, 2001). In this regard, Chart 37 suggests that during 2002 and 2003, credit rating downgrades of financial institutions outnumbered upgrades in Western Europe. In 2004 and early 2005, there was an improvement in credit quality as credit rating upgrades outnumbered downgrades.

The earnings performance for the euro area banking sector improved in 2003 and remained high in 2004 and early 2005. This was reflected, for example, in sustained strong growth in realised earnings per share of banks included in the Dow Jones EURO STOXX index (see Chart 38). Expected earnings per share, albeit at high level, have been on a downward trend since March 2003.

\section{Chart 38 Actual and short-term expected} bank earnings per share in the euro area

\section{(annual growth rates)}

DJ Euro Stoxx Bank expected 12-months EPS DJ Euro Stoxx Bank 12-months actual EPS

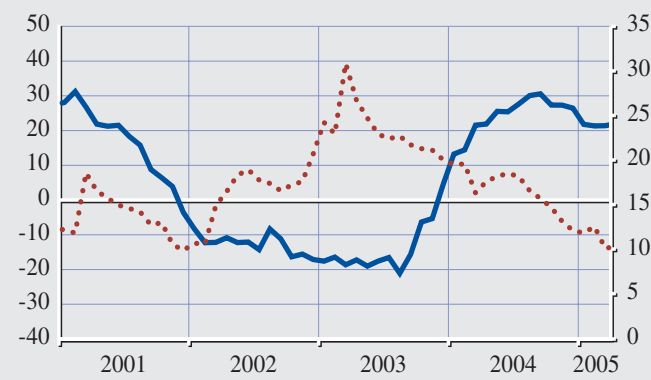

Source: Thomson Financial Datastream IBES.

In addition, spreads on euro-denominated subordinated debt by financial intermediaries were on a declining trend between the beginning of 2004 and the first quarter of 2005 , reflecting the general trend in corporate bond spreads, which is partly being driven by investors' search for yield, as well as expectations of an improved situation for financial intermediaries.
34 Two possible ways of dealing with these drawbacks are adjusting equity returns by the balance sheet position of banks, and/or also considering the volatility of stock returns. Two commonly used methodologies that try to do this are the expected default frequency and the distance to default. For more information, see ECB (2005b). 
Alexopoulou, I., G. de Bondt and A. van Rixtel (2005), "Globalization of the Bond and Stock Markets: The Japanese Case - an International Perspective", Capital Markets, Globalization and Economic Development, Gup, B. E. (ed.), Springer Verlag, New York, 77-107.

Allen, F. (1989), "The Changing Nature of Debt and Equity: A Financial Perspective", proceedings from the conference entitled "Are the Distinctions between Debt and Equity Disappearing?", organised by the Federal Reserve Bank of Boston, October 1989, 12-38.

Allen, F. and D. Gale (1995), “A Welfare Comparison of Intermediaries and Financial Markets in Germany and the US", European Economic Review, 39, 2, 179-209.

Allen, F. and D. Gale (1997), "Financial Markets, Intermediaries, and Intertemporal Smoothing”, Journal of Political Economy, 105, 3, 523-546.

Allen, F. and D. Gale (2000), Comparing Financial Systems, MIT Press, Cambridge, MA.

Amaro de Matos, J. (2001), Theoretical Foundations of Corporate Finance, Princeton University Press, Princeton.

Angeloni, I., A. Kashyap and B. Mojon (eds.) (2003), Monetary Policy Transmission in the Euro Area, Cambridge University Press, Cambridge.

Angeloni, I. et al. (2003), "The Output Composition Puzzle: a Difference in the Monetary Transmission Mechanism in the Euro Area and the United States", Journal of Money, Credit, and Banking, 35, 6, 1265-1306.

Aoki, K., J. Proudman and G. Vlieghe (2004), "House Prices, Consumption and Monetary Policy: A Financial Accelerator Approach", Journal of Financial Intermediation, 13, 4, 414-435.

Ayuso J. and F. Restoy (2003), "House Prices and Rents: An Equilibrium Asset Pricing Approach", Banco de España Working Paper, No 0304.

Banca d'Italia (1986), “Modello trimestrale dell' economia italiana”, Temi di Discussione, Banca d'Italia Working Papers, No 80.

Becht, B., P. Bolton and A. Röell (2003), "Corporate Governance and Control”, Handbook of the Economics of Finance, Constantinides, G., M. Harris and R. Stulz (eds.), North-Holland, Amsterdam, 1-109.

Berg, J., A. van Rixtel, A. Ferrando, G. de Bondt and S. Scopel, (2005), "The Bank Lending Survey for the Euro Area”, ECB Occasional Paper No 23, February 2005.

Bernanke, B. S. and M. Gertler (1987), "Banking and Macroeconomic Equilibrium", New Approaches to Monetary Economics, Barnett W. A. and K. Singleton (eds.), Cambridge University Press, New York, 89-111. 
Bernanke, B. S. and A. S. Blinder (1988), "Credit, Money, and Aggregate Demand", American Economic Review, 78, 2, 435-439.

Bernanke, B. S. and M. Gertler (1989), "Agency Costs, Net Worth, and Business Fluctuations", American Economic Review, 79, 1, 14-31.

Bondt, G. de (1999), "Credit channels and consumption in Europe: empirical evidence", BIS Working Paper, No 69.

Bondt, G. de (2002a), "Retail Bank Interest Rate Pass-through: New Evidence at the Euro Area Level”, ECB Working Paper, No 136.

Bondt, G. de (2002b), "Euro Area Corporate Debt Securities Market: First Empirical Evidence", ECB Working Paper, No 164.

Bondt, G. de (2003), "Has the Retail Bank Interest Rate Pass-through Been Atypical in 2002?", CESifo Forum, 4, 1, 42-46.

Bondt, G. de (2004), "The balance sheet channel of monetary policy: first empirical evidence for the euro area corporate bond market", International Journal of Finance and Economics, 9, 3, 219-228.

Bondt, G. de (2005a), "Interest Rate Pass-through: Empirical Results for the Euro Area”, German Economic Review 6, 1, 37-78.

Bondt, G. de (2005b), "Determinants of corporate debt securities in the euro area", European Journal of Finance, forthcoming.

Bondt, G. de and D. Marqués-Ibáñez (2004), "The High-Yield Segment of the Corporate Bond Market: A Diffusion Modelling Approach for the United States, the United Kingdom and the Euro Area", ECB Working Paper, No 313.

Bondt, G. de and D. Marqués-Ibáñez (2005), "High-Yield Bond Diffusion in the United States, the United Kingdom, and the Euro Area", Journal of Financial Services Research, 27, 2, 163-181.

Boot, A. W. A. and A. V. Thakor (1997), "Financial System Architecture", The Review of Financial Studies 10, 3, 693-733.

Borio, C. (1997), "Credit Characteristics and the Monetary Policy Transmission in Fourteen Industrial Countries", Monetary Policy in a Converging Europe, Alders K. (ed.), Kluwer, Amsterdam.

Borio, C. and P. Lowe (2002), "Asset Prices, Financial and Monetary Stability: Exploring the Nexus", BIS Working Paper, No 114.

Borio C., W. Hunter, G. Kaufman and K. Tsatsaronis (eds.) (2004), Market Discipline cross Countries and Industries, MIT Press, Cambridge, MA. 
Bottazzi, L. and M. Da Rin (2002), “Europe’s ‘New’ Stock Markets”, Bocconi University, IGIER Working Paper Series, No 218.

Bris, A., Y. Koskinen and M. Nilsson (2004), “The Euro and Corporate Valuations”, mimeo.

Byrne, J. P. and E. P. Davis (2003), Financial Structure: An Investigation of Sectoral Balancesheets in the G-7, Cambridge University Press, Cambridge.

Calza, A., C. Gartner and J. Sousa (2003), "Modelling the Demand for Loans to the Private Sector in the Euro Area", Applied Economics, 35, 1, 107-17.

Calza, A., M. Manrique and J. Sousa (2003), “Aggregate Loans to the Euro Area Private sector”, ECB Working Paper, No 202.

Casolaro, L., D. Focarelli, and A.F. Pozzolo (2003), "The Pricing Effect of Certification on Bank Loans: Evidence from the Syndicated Credit Market”, mimeo, Banca d'Italia.

Chami, R. and T. F. Cosimano (2001), "Monetary Policy with a Touch of Basel”, IMF Working Paper, No 01-151.

Collin-Dufresne, P., R. S. Goldstein and J. S. Martin (2001), “The Determinants of Credit Spread Changes", Journal of Finance, 56, 6, 2177-2207.

Damodaran, A. (1999), Applied Corporate Finance: A User's Manual, John Wiley, New York.

De Bandt O., L. M. de Belleville and O. Vazeille (2001), "Spring 2001 Broad Macroeconomic Projection Exercise: Loans to the Private Sector by French MFIs", Banque de France, mimeo.

Debelle, G. (2004), "Household Debt and the Macroeconomy”, BIS Quarterly Review, March.

Dennis, S. A. and D. J. Mullineaux (2000), "Syndicated Loans", Journal of Financial Intermediation, 9, 4, October, 404-426.

Diamond, D. W. (1984), "Financial Intermediation and Delegated Monitoring", Review of Economic Studies, 51, 3, 393-414.

Duca, J. V. (1999), "What Credit Market Indicators Tell Us", Federal Reserve Bank of Dallas Economic and Financial Review, third quarter, 1-13.

Elton, E. J., M. J. Gruber, D. Agrawal and C. Mann, (2001), "Explaining the Rate Spread on Corporate Bonds", Journal of Finance, 56, 1, 247-277.

Estrella, A., S. Park and S. Peristiani (2000), "Capital Ratios as Predictors of Bank Failure", Federal Reserve Bank of New York, Economic Policy Review, 6, 2, 33-52.

European Central Bank (2000), "Monetary Policy Transmission in the Euro Area", Monthly Bulletin, July, 43-58. 
European Central Bank (2001), "Characteristics of Corporate Finance in the Euro Area", Monthly Bulletin, February, 37-50.

European Central Bank (2003a), Box on "New ECB Statistics on MFI Interest Rates", Monthly Bulletin, December, 23-25.

European Central Bank (2003b), Structural Factors in the EU Housing Markets, ECB.

European Central Bank (2003c), "Developments in the Debt Financing of the Euro Area Private Sector", Monthly Bulletin, November, 47-58.

European Central Bank (2004a), "The Link between Asset Prices and Monetary Developments", Monthly Bulletin, September, 20-21.

European Central Bank (2004b), Box on "Developments in Private Sector Balance Sheets in the Euro Area and the United States", Monthly Bulletin, February, 57-67.

European Central Bank (2004c), Box on "Features of Mortgage Contracts in the Euro Area", Monthly Bulletin, November, 14-16.

European Central Bank (2004d), Box on 'Developments in Banks' Loan-loss Provisions over Recent Years", Monthly Bulletin, March, 37-39.

European Central Bank (2004e), "Accounting for the Resilience of the EU Banking Sector", Monthly Bulletin, July, 59-70.

European Central Bank (2004f), Financial Stability Review, ECB.

European Central Bank (2004g), EU Banking Sector Stability, ECB.

European Central Bank (2005a), Box on "A Measure of the Real Cost of the External Financing of Euro Area Non-financial Corporations", Monthly Bulletin, March, 38-40.

European Central Bank (2005b), "Bank Market Discipline", Monthly Bulletin, February, 55-64.

Eurostat (1996), European System of Accounts (ESA 95), Eurostat.

Fabozzi, F. and F. Modigliani (1996), Capital Markets: Institutions and Instruments, Prentice Hall, Upper Saddle River, NJ.

Fama, E. F. and K. R. French (2005), "Financing Decisions: Who Issues Stock?”, Journal of Financial Economics, forthcoming.

Fase, M. M. G. and G. de Bondt (2000), "Institutional Environment and Monetary Transmission in the euro area: a Cross-country View", Revue de la Banque / Bank- en Financiewezen, 64, 2-3, 149-155.

Fase, M. M. G., P. Kramer and W. C. Boeschoten (1992), "MORKMON II: The Nederlandsche Bank's Quarterly Model of the Netherlands Economy", Economic Modelling, 9, 2, 146-204. 
Fenn, G, N. Liang and S. Prowse (1995), "The Economics of the Private Equity Market", Board of Governors of the Federal Reserve System, Staff Study No 168.

Flannery, M. (1998), Using Market Information in Prudential Bank Supervision: A Review of the US Empirical Evidence", Journal of Money, Credit and Banking, 30, 3, 273-305.

Flannery, M., S. Kwan and M. Nimalendren (2004), "Market Evidence on the Opaqueness of Banking Firms' Assets", Journal of Financial Economics, 71, 3, 419-460.

Friedman, B.M. and K. N. Kuttner (1998), "Indicator Properties of the Paper-bill Spread: Lessons from Recent Experience", Review of Economics and Statistics, 80, 1, 34-44.

Gadanecz, B. and K. von Kleist (2003), "Do Syndicated Credits Anticipate BIS Consolidated Banking Data?", IFC Bulletin, 14.

Gertler, M. (1988), "Financial Structure and Aggregate Economic Activity: An Overview", Journal of Money, Credit and Banking, 20, 3, Part 2, 559-588.

Graham, J. R. and C. R. Harvey (1999), “The Theory and Practice of Corporate Finance: Evidence from the Field", mimeo.

Greenwald, B. and J. E. Stiglitz (1993), "Financial Market Imperfections and Business Cycles", Quarterly Journal of Economics, 108, 1, 77-114.

Greenwald, B., J. E. Stiglitz and A. Weiss (1984), "Informational Imperfections in the Capital Market and Macroeconomic Fluctuations", American Economic Review, 74, 2, 194-200.

Greenwald, B. and J. E. Stiglitz (2003), Towards a New Paradigm in Monetary Economics, Cambridge University Press, Cambridge.

Gropp, R. and A. J. Richards (2001), "Rating Agency Actions and the Pricing of Debt and Equity of European Banks: What Can We Infer about Private Sector Monitoring of Bank Soundness?", Economic Notes, 30, 3, 373-398.

Gropp R., J. Vesala and G. Vulpes (2002), "Equity and Bond Market Signals as Leading Indicators of Bank Fragility", ECB Working Paper, No 150.

Gropp R., J. Vesala and G. Vulpes (2005), "Equity and Bond Market Signals as Leading Indicators of Bank Fragility", Journal of Money, Credit and Banking, forthcoming.

Hamilton, J. D. and D. H. Kim (2002), A Re-examination of the Predictability of Economic Activity Using the Yield Spread", Journal of Money, Credit, and Banking, 34, 2, 340-360.

Hernando, I. and C. Martinez-Carrascal (2003), “The Impact of Financial Variables on Firms' Real Decisions: Evidence from Spanish Firm-level Data", Banco de España Working Paper, No 0319. 
Herring, R.J. and N. Chatusripitak (2001), "The Case of the Missing Market: The Bond Market and Why It Matters for Financial Development", The Wharton School, University of Pennsylvania, Financial Institutions Center Working Paper, No 01-08.

Hovakimian, A., G. Hovakimian and H. Tehranian (2004), "Determinants of Target Capital Structure: The Case of Dual Debt and Equity Issues", Journal of Financial Economics, 71, 3, 517-540.

Huang, J. and M. Huang (2003), "How Much of the Corporate-Treasury Yield Spread is due to Credit Risk?", mimeo, May.

Hubbard, R. G. (1998), "Capital-market Imperfections and Investment", Journal of Economic Literature, 36, 1, 193-225.

Hull, J. C. (2000), Options, Futures and Other Derivatives, Prentice Hall, Upper Saddle River, NJ.

Jaeger, A. (2003), "Corporate Balance-sheet Restructuring and Investment in the Euro Area", IMF Working Paper, No 03-117.

James, C. (1987), "Some Evidence on the Uniqueness of Bank Loans", conference proceedings, Federal Reserve Bank of San Francisco.

La Porta, R. (1998), “Law and Finance”, Journal of Political Economy, 106, 6, 1113-1155.

Laeven, L. and G. Majnoni (2002), "Loan Loss Provisioning and Economic Slowdowns: Too Much, too Late?", The World Bank, Policy Research Working Paper, No 2749.

Landschoot, A. van (2004), "Determinants of Euro Term Structure of Credit Spreads", ECB Working Paper Series, No 397.

Leland, H. and D. Pyle (1977), "Informational Asymmetries, Financial Structure and Financial Intermediation", Journal of Finance, 32, 2, 371-387.

Ljungqvist, A. and W. J. Wilhelm Jr. (2003), "IPO Pricing in the Dot-com Bubble", Journal of Finance, 58, 2, 723-752.

Lowry, M. and G. W. Schwert (2002), "IPO Market Cycles: Bubbles or Sequential Learning?", Journal of Finance, 57, 3, 1171-1200.

Maclennan, D., J. Muellbauer and M. Stephens (1998), “Asymmetries in Housing and Financial Market Institutions and EMU”, Oxford Review of Economic Policy, 14, 3, 54-80.

Merton, R. C. (1974), "On the Pricing of Corporate Debt: The Risk Structure of Interest Rates", Journal of Finance, 29, 2, 449-470.

Milgrom, P. and J. Roberts (1992), Economics, Organization and Management, Prentice Hall, Englewood Cliffs, NJ. 
Mishkin, F. S. and S. G. Eakins (1999), Financial Markets and Institutions, Addison Wesley Longman, Boston, MA.

Modigliani, F. and M. H. Miller (1958), "The Cost of Capital, Corporation Finance and the Theory of Investments", American Economic Review, 48, 3,261-297.

Montoya, M. and S. Trimbath (2002), “A New Kind of Gold? Investment in Housing in Times of Economic Uncertainty”, Milken Institute Policy Brief, No 30.

Moody's (2003), “Downgrades Continue to Outnumber Upgrades in Western Europe, but the Gap is Narrowing”, Moody's Investors Service European Credit Trends, Q2 2003.

Myers, S. C. (1977), "Determinants of Corporate Borrowing”, Journal of Financial Economics, $5,2,147-175$.

Myers, S. C. (1984), “The Capital Structure Puzzle”, Journal of Finance, 39, 3, 575-592.

Myers, S. C. and N. S. Majluf (1984), "Corporate Financing and Investment Decisions When Firms Have Information that Investors Do Not Have", Journal of Financial Economics, 13, 2 , $187-221$.

Myers, S. C. (2003), "Financing of Corporations", Handbook of the Economics of Finance, Constantinides G., M. Harris and R. Stulz (eds.) 2003, North-Holland, Amsterdam, 215-253.

Pagano, M., F. Panetta and L. Zingales (1996), “The Stock Market as a Source of Capital: Some Lessons from Initial Public Offerings in Italy", European Economic Review, 40, 3-5, 1057-1069.

Pagano, M., F. Panetta and L. Zingales (1998), "Why Do Companies Go Public? An Empirical Analysis", Journal of Finance, 53, 1, 27-64.

Paranque, B. and H. Friderichs (1999), "The Issue of Corporate Finance: Theoretical Approaches and Previous Empirical Results", Sauvé, A. and M. Scheuer (eds.), 1999, Corporate Finance in Germany and France: A Joint Research Project of the Deutsche Bundesbank and the Banque de France, Corporate Finance in Germany and France, Deutsche Bundesbank, 73-137.

Peek, J., E. S. Rosengren and G. M. B. Tootell (2003), "Does the Federal Reserve Possess an Exploitable Informational Advantage?", Journal of Monetary Economics, 50, 4, 817-839.

Perraudin, W. R. M. and A. P. Taylor (2003), “Liquidity and Bond Market Spreads”, mimeo, June.

Rajan, R. G. and L. Zingales (2003), "The Great Reversals: The Politics of Financial Development in the Twentieth Century", Journal of Financial Economics, 69, 1, 5-50.

Ritter, J. R. (2003a), "Investment Banking and Securities Issuance”, Handbook of the Economics of Finance, Constantinides, G., M. Harris and R. Stulz (eds.), 2003, North-Holland, Amsterdam, 255-306. 
Ritter, J. R. (2003b), "Differences between European and American IPO Markets", European Financial Management, 9, 4, 421-434.

Rixtel, A. van (2002), Informality and Monetary Policy in Japan: The Political Economy of Bank Performance, Cambridge University Press, Cambridge.

Ross, S. A. (1973), "The Economic Theory of Agency: The Principal's Problem", American Economic Review, 63, 2, 134-139.

Ross, S. A. (1977), "The Determination of Financial Structure: The Incentive-signalling Approach", Bell Journal of Economics, 8, 1, 23-40.

Santillan, J., A. van Rixtel and D. Marqués-Ibáñez (2000), "Main Changes in the Financial Structure of the Euro-zone since the Introduction of the Euro", OECD, Financial Markets Trends, $76,109-129$.

Saunders, A. (2002), Financial Institutions Management: A Risk Management Approach, R. D. Irwin, New York.

Schmidt, R. H., A. Hackethal and M. Tyrell (1999), "Disintermediation and the Role of Banks in Europe: An International Perspective", Journal of Financial Intermediation, 8, 1-2, 36-67.

Schuster, J. A. (2003), "The Cross-section of European IPO Returns", mimeo, London School of Economics, August.

Stock, J. H. and M. W. Watson (1989), "New Indexes of Coincident and Leading Indicators", NBER Macro-economics Annual, O. Blanchard and S. Fisher (eds.), MIT Press, Cambridge, MA, 352-394.

Stulz, R. (1999), "Globalization of Capital Markets and the Cost of Capital", Journal of Applied Corporate Finance, Fall, 8-25.

Sinkey, J. F. (2001), Commercial Bank Financial Management, Prentice Hall.

Teplin, A. et al. (2004), "Integrated Macroeconomic Accounts for the United States", paper presented at the Conference on Research in Income and Wealth Architecture of National Accounts, 16-17 April 2004.

Van den Heuvel, S. J. (2002), “Does Bank Capital Matter for Monetary Transmission?", Federal Reserve Bank of New York, Economic Policy Review, May, 259-265.

Walsh, C. E. (1998), Monetary Theory and Policy, MIT Press, Cambridge, MA.

Zingales, L. (2000), "In Search of New Foundations", Journal of Finance, 55, 4, 1623-1653. 
Non-financial corporations

a) Cost of finance

Item

Definition

Source

Bank interest rates Percentages per annum

Interest rates that are applied by resident MFIs (Monetary Financial ECB: MIR, RIR. Institutions) to euro-denominated deposits and loans vis-à-vis nonfinancial corporations resident in the euro area.

$\begin{array}{ll}\begin{array}{ll}\text { Cost of market } \\ \text { based debt }\end{array} & \begin{array}{l}\text { Percentages per } \\ \text { annum }\end{array}\end{array}$

The calculation of the real cost of market-based debt is based on the Merrill Lynch, EMU non-financial Merrill Lynch index of the average yield of Thomson Financial corporate bonds with a maturity of over one year issued by euro area non-financial corporations with investment grade ratings (data Datastream, ECB available since April 1998), corporate bond yields in the six largest euro area countries in the period before April 1998 and the Merrill Lynch euro high-yield index.

\begin{tabular}{|c|c|c|c|}
\hline $\begin{array}{l}\text { Cost of quoted } \\
\text { equity }\end{array}$ & $\begin{array}{l}\text { Percentages per } \\
\text { annum }\end{array}$ & $\begin{array}{l}\text { See ECB (2005a) for an explanation on the construction of this } \\
\text { indicator. The estimation of the real cost of equity is measured by the } \\
\text { three-stage Gordon dividend discount model, which states that the } \\
\text { price of a share is equivalent to the expected discounted sum of all } \\
\text { future dividends paid out by the corporation. From this, it is possible } \\
\text { to find a measure of the cost of equity that depends on the current } \\
\text { dividend yield and on the growth rates of dividends in the future. }\end{array}$ & $\begin{array}{l}\text { Thomson Financial } \\
\text { Datastream, ECB } \\
\text { calculations. }\end{array}$ \\
\hline $\begin{array}{l}\text { Corporate bond } \\
\text { spreads }\end{array}$ & Basis points & $\begin{array}{l}\text { Difference between the yields on euro-denominated corporate bonds } \\
\text { and those on comparable government bonds. }\end{array}$ & $\begin{array}{l}\text { Merrill Lynch, } \\
\text { Bloomberg. }\end{array}$ \\
\hline $\begin{array}{l}\text { Terms and } \\
\text { conditions } \\
\text { affecting credit } \\
\text { standards }\end{array}$ & Percentages & $\begin{array}{l}\text { The terms and conditions of a loan refer to the specific obligations } \\
\text { agreed by the lender and the borrower. In the context of the Bank } \\
\text { Lending Survey, they consist of the direct price or interest rate, the } \\
\text { maximum size of the loan and the access conditions, as well as other } \\
\text { terms and conditions in the form of non-interest rate charges (i.e. } \\
\text { fees), collateral requirements (including compensating balances), } \\
\text { loan covenants and maturity (short versus long-term). The net } \\
\text { percentage refers to the difference between the sum of the } \\
\text { percentages for "tightened considerably" and "tightened somewhat" } \\
\text { and the sum of the percentages for "eased somewhat" and "eased } \\
\text { considerably". For a detailed explanation, see Berg, J., A. van Rixtel, } \\
\text { A. Ferrando, G. de Bondt and S. Scopel (2005). }\end{array}$ & $\begin{array}{l}\text { ECB: Bank } \\
\text { Lending Survey. }\end{array}$ \\
\hline
\end{tabular}

\section{b) Sources of finance}

Bank loans to non- Growth rates; financial flows corporations

Syndicated loans Gross issuance

Debt securities Growth rates; flows
Loans granted by euro area MFIs to non-financial corporations. (QFA data also include loans granted by non-monetary financial corporations). From September 1997 onwards: official data. Before September 1997: estimates based on national data.

Large loans in which a group of banks work together to provide funds Thomson One for a borrower. In our analysis, we consider only syndicated loans Banker Deals. granted by euro area banks.

A promise on the part of the issuer (i.e. the borrower) to make one or more payment(s) to the holder (the lender) on a specified future date or dates. Such securities usually carry a specific rate of interest (coupon) and/or are sold at a discount to the amount that will be repaid at maturity.

\section{1) Abbreviations:}

QFA: Euro area quarterly financial accounts.

AFA: Euro area annual financial accounts.

BSI: MFI balance sheet.

ANFA: Euro area annual non-financial accounts.

MIR: MFI interest rates statistics (Eurosystem' interest rates statistics available from January 2003 onwards).

RIR: Retail interest rates (Eurosystem' interest rates statistics available from January 1990 to September 2003). 


\section{ANNEX OVERVIEW OF INDICATORS OF FINANCING CONDITIONS (cond't)}

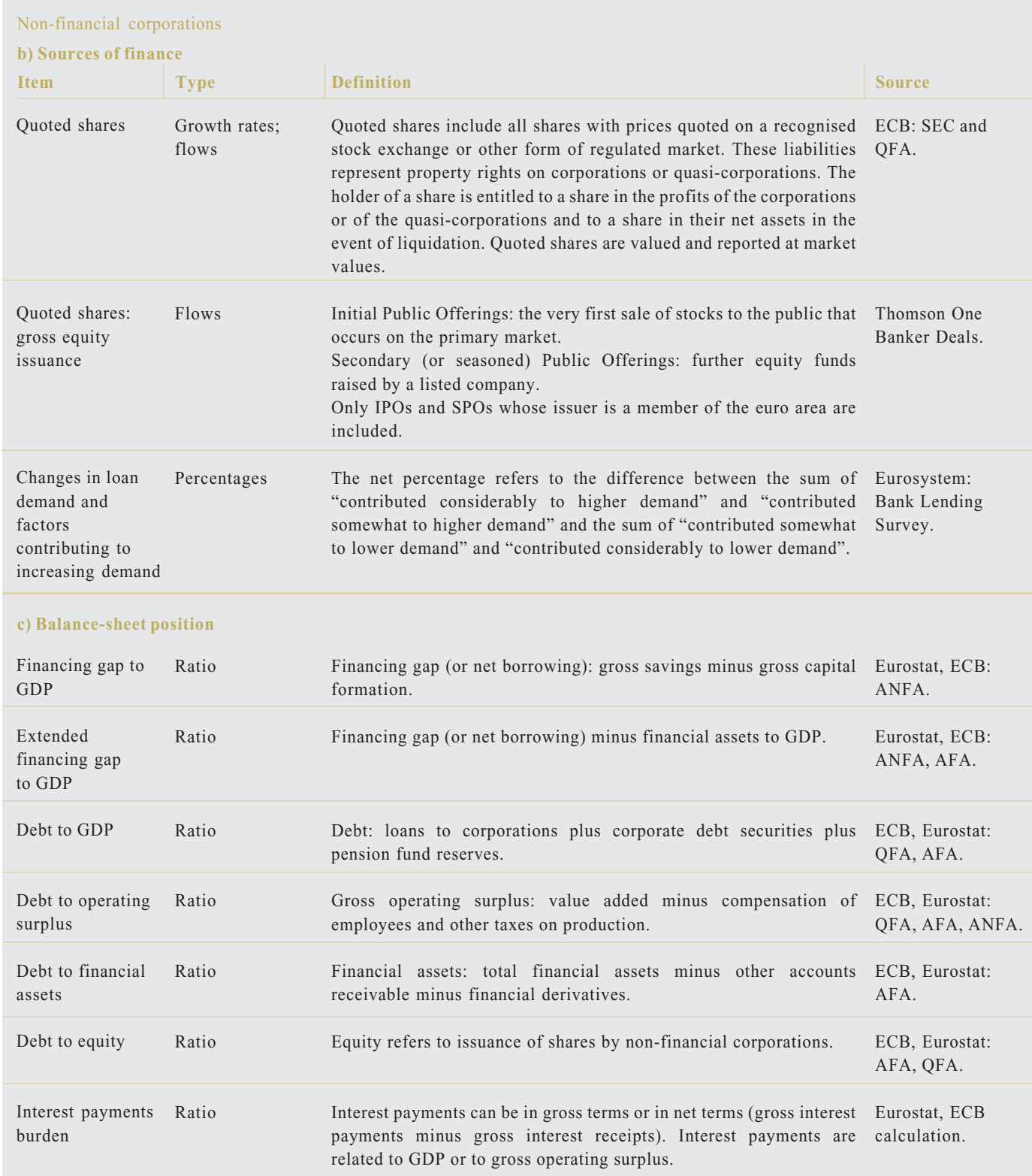


Households

a) Cost of finance

\begin{tabular}{l|l|l|l} 
Item & Type & Definition
\end{tabular}

Bank interest rates Percentages per Interest rates that are applied by resident credit institutions and other ECB: MIR, RIR annum MFIs, excluding central banks and money market funds, to eurodenominated loans vis-à-vis households resident in the euro area.

b) Sources of finance

Loan

Growth rates; flows

Loans granted by euro area MFIs to households. (QFA data also ECB: BSI, QFA. include loans granted by non-monetary financial corporations). MFI loans to households include three major categories: consumer loans, loans for house purchase and other lending.

From September 1997 onwards: official data.

Before September 1997: estimates based on national data

Changes in credit Percentages standards and

factors

contributing to

tightening credit

standards.
The net percentage refers to the difference between the sum of Eurosystem: "contributed considerably to tightening" and "contributed somewhat Bank Lending to tightening" and the sum of "contributed somewhat to easing" and Survey. "contributed considerably to easing". For more details, see Berg,

J., A. van Rixtel, A. Ferrando, G. de Bondt and S. Scopel (2005).

\section{c) Balance-sheet position}

Net lending / net Ratio borrowing to GDP

Debt to GDP Ratio

Debt to disposable Ratio income

Debt to financial Ratio

assets

Debt deflated by Amounts

house prices Outstanding

Debt service

burden

Ratio

Debt service

Ratio

including principal

payments
Net lending: gross saving minus gross capital formation.

Eurostat, ECB:

ANFA.

Debt: outstanding loans taken by households.

ECB, Eurostat: QFA, AFA.

Disposable income: value added minus compensation of employees ECB, Eurostat: minus other taxes on production, plus net property income, plus net QFA, AFA. social contributions/benefits plus net other current transfers.

Financial assets: total financial assets minus other accounts ECB, Eurostat: receivable minus financial derivatives.

AFA.

Debt deflated by the house price deflator (internal proxy for euro area ECB: AFA, QFA,

house price deflator derived as weighted average of non ECB calculation.

homogeneous national indexes).

Gross interest payments or net interest payments (interest payments minus interest receipts) to disposable income (or GDP).

Eurostat, ECB

calculation,

ANFA

Gross (or net) interest payments plus payments of principal to Eurostat, ECB disposable income (or GDP). Payment of principal is estimated from calculation. the structure of loans to households by (partly estimated) maturity. 


\section{ANNEX OVERVIEW OF INDICATORS OF FINANCING CONDITIONS (cond't}

\begin{tabular}{|c|c|c|c|}
\hline \multicolumn{4}{|l|}{$\begin{array}{l}\text { Banks } \\
\text { a) Cost of finance }\end{array}$} \\
\hline Item & Type & Definition & Source \\
\hline Bank interest rates & Rate & $\begin{array}{l}\text { Interest rates that are applied by resident credit institutions and other } \\
\text { MFIs, excluding central banks and money market funds, to euro- } \\
\text { denominated deposits and loans vis-à-vis households and non- } \\
\text { financial corporations resident in the euro area. }\end{array}$ & ECB: MIR, RIR. \\
\hline $\begin{array}{l}\text { Bank interest } \\
\text { rates, spreads on } \\
\text { market rates }\end{array}$ & Basis points & $\begin{array}{l}\text { Interest rate data are deflated by the Consensus Economics Forecast } \\
\text { inflation expectations. MFI interest rates have been aggregated using } \\
\text { amounts outstanding whenever available. Otherwise, aggregated } \\
\text { new business volumes for } 2003 \text { have been used. In January } 2003 \text { there } \\
\text { was a statistical break in the interest rate series. To take this into } \\
\text { account, past levels of previous interest rate statistics (RIR) data } \\
\text { were adjusted on the basis of the difference between the old and the } \\
\text { new interest rate statistics levels in January } 2003 \text {. }\end{array}$ & ECB: MIR, RIR. \\
\hline $\begin{array}{l}\text { Bank and } \\
\text { insurance stock } \\
\text { market indices }\end{array}$ & Ratio & Datastream EMU banks and insurance indices. & $\begin{array}{l}\text { Thomson Financial } \\
\text { Datastream. }\end{array}$ \\
\hline \multicolumn{4}{|c|}{ c) Balance-sheet position } \\
\hline $\begin{array}{l}\text { Core capital to } \\
\text { total assets }\end{array}$ & Ratio & $\begin{array}{l}\text { Core capital or TIER } 1 \text { (includes stock issues, retained earnings, as } \\
\text { well as other disclosed reserves, but not intangibles or good will) to } \\
\text { total assets. }\end{array}$ & Bankscope. \\
\hline $\begin{array}{l}\text { Market to book } \\
\text { value }\end{array}$ & Ratio & $\begin{array}{l}\text { Stock market price of a bank share multiplied by the number of shares } \\
\text { outstanding and divided by the accounting value of total capital. }\end{array}$ & Bloomberg. \\
\hline $\begin{array}{l}\text { Loan loss } \\
\text { provision to net } \\
\text { interest income }\end{array}$ & Ratio & $\begin{array}{l}\text { Loan-loss provisions to net interest income (interest income minus } \\
\text { interest revenue). }\end{array}$ & Bankscope. \\
\hline Return on assets & Ratio & $\begin{array}{l}\text { Net income (refers to interest and dividend income, minus interest } \\
\text { expense) to average total assets. }\end{array}$ & Bankscope. \\
\hline $\begin{array}{l}\text { Changes in credit } \\
\text { standards and } \\
\text { factors } \\
\text { contributing to } \\
\text { tightening credit } \\
\text { standards }\end{array}$ & Percentages & $\begin{array}{l}\text { The net percentage refers to the difference between the sum of } \\
\text { "contributed considerably to tightening" and "contributed somewhat } \\
\text { to tightening" and the sum of "contributed somewhat to easing" and } \\
\text { "contributed considerably to easing". }\end{array}$ & $\begin{array}{l}\text { ECB: } \\
\text { Bank Lending } \\
\text { Survey. }\end{array}$ \\
\hline $\begin{array}{l}\text { Financial sector } \\
\text { rating changes }\end{array}$ & Number & Number of upgrades and (minus) downgrades in Western Europe. & $\begin{array}{l}\text { Moody's Investor } \\
\text { Service. }\end{array}$ \\
\hline $\begin{array}{l}\text { Bank earnings per } \\
\text { share }\end{array}$ & Growth rates & $\begin{array}{l}\text { A measure of the total return earned by a bank on its ordinary share } \\
\text { capital. The Institutional Brokers Estimate System (I/B/E/S) series } \\
\text { are estimates by analysts rather than reports or forecasts by } \\
\text { companies of their own earnings. }\end{array}$ & $\begin{array}{l}\text { Thomson Financial } \\
\text { Datastream IBES. }\end{array}$ \\
\hline
\end{tabular}




\section{EUROPEAN CENTRAL BANK}

OCCASIONAL PAPER SERIES

1 "The impact of the euro on money and bond markets" by J. Santillán, M. Bayle and C. Thygesen, July 2000.

2 "The effective exchange rates of the euro" by L. Buldorini, S. Makrydakis and C. Thimann, February 2002.

3 "Estimating the trend of M3 income velocity underlying the reference value for monetary growth" by C. Brand, D. Gerdesmeier and B. Roffia, May 2002.

4 "Labour force developments in the euro area since the $1980 \mathrm{~s}$ " by V. Genre and R. Gómez-Salvador, July 2002.

5 "The evolution of clearing and central counterparty services for exchange-traded derivatives in the United States and Europe: a comparison" by D. Russo, T. L. Hart and A. Schönenberger, September 2002.

6 "Banking integration in the euro area" by I. Cabral, F. Dierick and J. Vesala, December 2002.

7 "Economic relations with regions neighbouring the euro area in the "Euro Time Zone"" by F. Mazzaferro, A. Mehl, M. Sturm, C. Thimann and A. Winkler, December 2002.

8 "An introduction to the ECB's survey of professional forecasters" by J. A. Garcia, September 2003.

9 "Fiscal adjustment in 1991-2002: stylised facts and policy implications" by M. G. Briotti, February 2004.

10 "The acceding countries' strategies towards ERM II and the adoption of the euro: an analytical review" by a staff team led by P. Backé and C. Thimann and including O. Arratibel, O. Calvo-Gonzalez, A. Mehl and C. Nerlich, February 2004.

11 "Official dollarisation/euroisation: motives, features and policy implications of current cases" by A. Winkler, F. Mazzaferro, C. Nerlich and C. Thimann, February 2004.

12 "Understanding the impact of the external dimension on the euro area: trade, capital flows and other international macroeconomic linkages" by R. Anderton, F. di Mauro and F. Moneta, March 2004.

13 "Fair value accounting and financial stability" by a staff team led by A. Enria and including L. Cappiello, F. Dierick, S. Grittini, A. Maddaloni, P. Molitor, F. Pires and P. Poloni, April 2004.

14 "Measuring Financial Integration in the Euro Area" by L. Baele, A. Ferrando, P. Hördahl, E. Krylova, C. Monnet, April 2004. 
15 "Quality adjustment of European price statistics and the role for hedonics" by H. Ahnert and G. Kenny, May 2004.

16 "Market dynamics associated with credit ratings: a literature review" by F. Gonzalez, F. Haas, R. Johannes, M. Persson, L. Toledo, R. Violi, M. Wieland and C. Zins, June 2004.

17 “Corporate 'Excesses' and financial market dynamics" by A. Maddaloni and D. Pain, July 2004.

18 "The international role of the euro: evidence from bonds issued by non-euro area residents" by A. Geis, A. Mehl and S. Wredenborg, July 2004.

19 "Sectoral specialisation in the EU a macroeconomic perspective" by MPC task force of the ESCB, July 2004.

20 "The supervision of mixed financial services groups in Europe" by F. Dierick, August 2004.

21 "Governance of securities clearing and settlement systems" by D. Russo, T. Hart, M. C. Malaguti and C. Papathanassiou, October 2004.

22 "Assessing potential output growth in the euro area: a growth accounting perspective" by A. Musso and T. Westermann, January 2005.

23 "The bank lending survey for the euro area" by J. Berg, A. van Rixtel, A. Ferrando, G. de Bondt and S. Scopel, February 2005.

24 "Wage diversity in the euro area: an overview of labour cost differentials across industries" by V. Genre, D. Momferatou and G. Mourre, February 2005.

25 "Government debt management in the euro area: recent theoretical developments and changes in practices" by G. Wolswijk and J. de Haan, March 2005.

26 "The analysis of banking sector health using macro-prudential indicators" by L. Mörttinen, P. Poloni, P. Sandars and J. Vesala, March 2005.

27 "The EU budget - how much scope for institutional reform?" by H. Enderlein, J. Lindner, O. Calvo-Gonzalez, R. Ritter, April 2005.

28 "Reforms in selected EU network industries" by R. Martin, M. Roma, I. Vansteenkiste, April 2005.

29 "Wealth and asset price effects on economic activity", by F. Altissimo, E. Georgiou, T. Sastre, M. T. Valderrama, G. Sterne, M. Stocker, M. Weth, K. Whelan, A. Willman, June 2005.

30 "Competitiveness and the export performance of the euro area", by a Task Force of the Monetary Policy Committee of the European System of Central Banks, June 2005.

31 "Regional monetary integration in the member states of the Gulf Cooperation Council (GCC)" by M. Sturm and N. Siegfried, June 2005. 
32 "Managing Financial Crises in Emerging Market Economies: Experience with the Involvement of Private Sector Creditors", by an International Relations Committee task force, July 2005.

33 "Integration of securities market infrastructures in the euro area", by H. Schmiedel, A. Schönenberger, July 2005.

34 "Hedge funds and their implications for financial stability", by T. Garbaravicius and F. Dierick, August 2005.

35 "The institutional framework for financial market policy in the USA seen from an EU perspective”, by R. Petschnigg, September 2005.

36 "Economic and monetary integration of the new Member States: helping to chart the route" by J. Angeloni, M. Flad and F. P. Mongelli, September 2005.

37 "Financing conditions in the euro area" by L. Bê Duc, G. de Bondt, A. Calza, D. Marqués Ibáñez, A. van Rixtel and S. Scopel, September 2005. 
